\begin{tabular}{|l|l|}
\hline $\begin{array}{l}\text { 2. To: (Receiving Organization) } \\
\text { SNE Sludge Project Definition }\end{array}$ & $\begin{array}{l}\text { 3. From: (Originating Organization) } \\
\text { Criticality Support }\end{array}$ \\
\hline $\begin{array}{l}\text { 5. Proj./Prog./Dept./Div: } \\
\text { Nuclear Safety \& Licensing }\end{array}$ & $\begin{array}{l}\text { 6. Design Authority/Design Agent/Cog. Engr.: } \\
\text { C.A. Rogers }\end{array}$ \\
\hline $\begin{array}{l}\text { 8. Originator Remarks: } \\
\text { This transmits the Validation Report for the XSDRNPM computer code } \\
\text { for performing criticality safety calculations for receipt of } \mathrm{K} \\
\text { Basin sludge at Tank Farms. }\end{array}$
\end{tabular}

11. Receiver Remarks:

11A. Design Baseline Document? $\bigcirc$ Yes $\otimes$ No

\begin{tabular}{|} 
4. Related EDT No.: \\
N/A \\
$\begin{array}{c}\text { 7. Purchase Order No:: } \\
\mathrm{N} / \mathrm{A}\end{array}$ \\
$\mathrm{N} / \mathrm{A}$ \\
\hline 9. Equip./Component No.: \\
TWRS \\
10. System/Bidg./Facility: \\
12. Major Assm. Dwg. No.: \\
N A
\end{tabular}

13. Permit/Permit Application No::

$\mathrm{N} / \mathrm{A}$

14. Required Response Date:

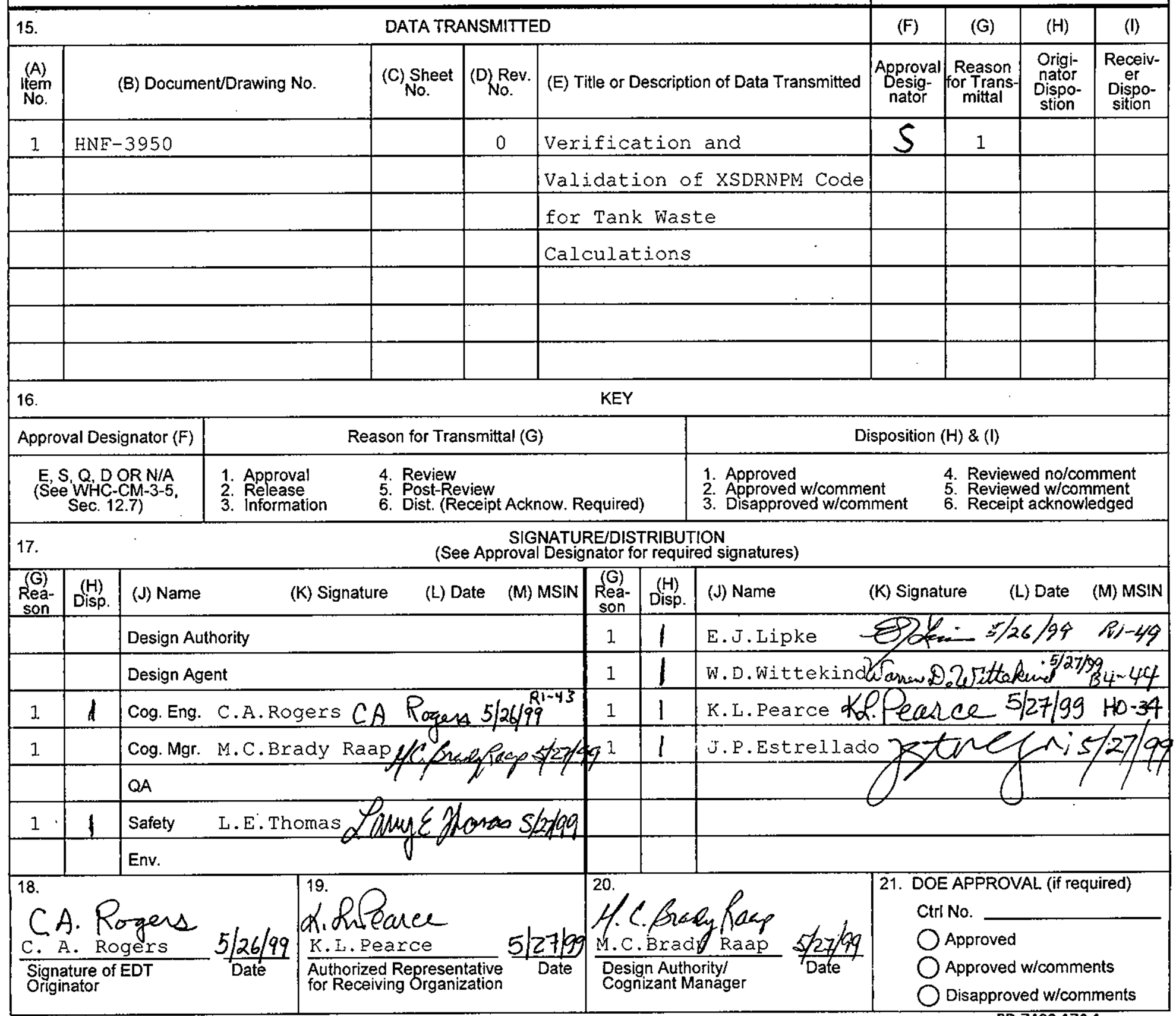




\title{
Verification and Validation of XSDRNPM Code for Tank Waste Calculations
}

\author{
Charles A. Rogers \\ Lockheed Martin Hanford Corporation \\ Richland, WA 99352 \\ U.S. Department of Energy Contract DE-AC06-96RL13200 \\ EDT/ECN: 625119 \\ UC: 2030 \\ Org Code: 74200 \\ Charge Code: 105618 \\ B\&R Code: 1LDH010205 \\ Total Pages:

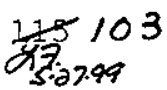

Key Words: XSDRNPM, K Basin Sludge, Criticality Safety Calculations, validation, Verification

Abstract: This validation study demonstrates that the XSDRNPM computer code accurately calculates the infinite neutron multiplication for water-moderated systems of low enriched uranium, plutonium, and iron. Calculations are made on a $200 \mathrm{MHz}$ Bravo MS 5200M personal computer using the SCALE 27-group ENDE/B-IV and 44-group ENDE/B-V cross section libraries. Upper Safety Limits of 0.881 and 0.882 are found for the 27-group and 44-group cross sections, respectively.

TRADEMARK DISCLAIMER. Reference herein to any specific commercial product, process, or service by trade name, trademark, manufacturer, or otherwise, does not necessarily constitute or imply its endorsement, recommendation, or favoring by the United States Government or any agency thereof or its contractors or subcontractors.

Printed in the United States of America. To obtain copies of this document, contact: Document Control Services, P.O. Box 950, Mailstop H6-08, Richland WA 99352, Phone (509) 372-2420; Fax (509) 376-4989.

DOCUMENT DOES NOT CONTAIN ECI

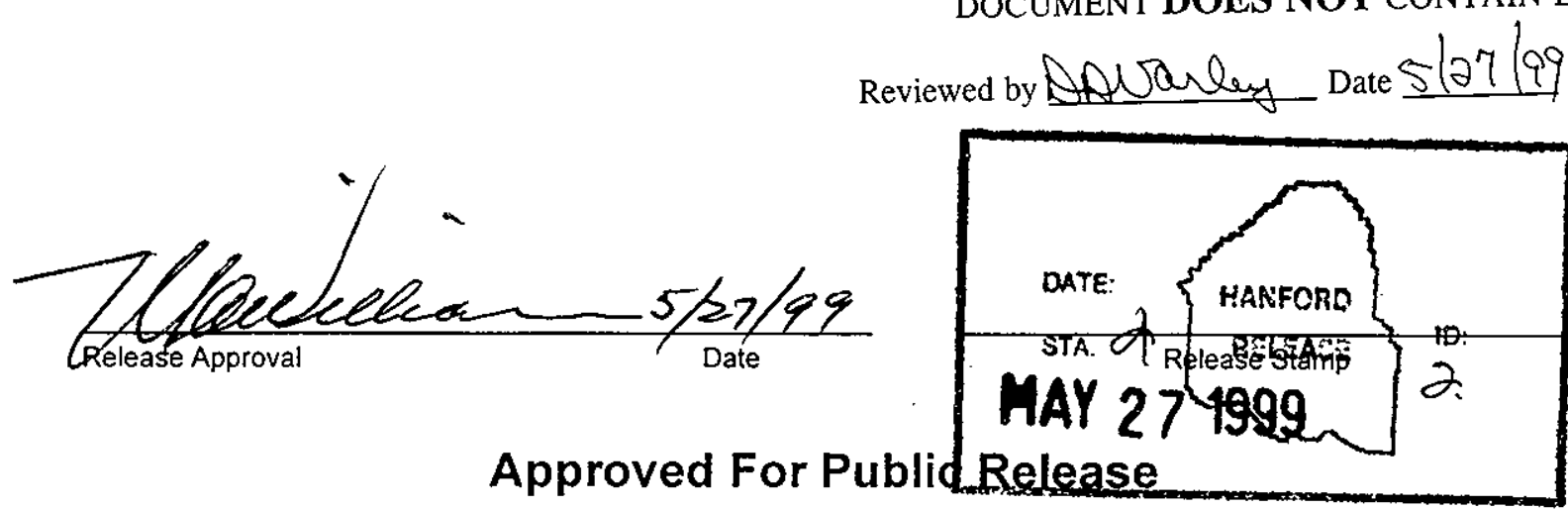




\section{Verification and Validation of XSDRNPM Code for Tank Waste Calculations}

C. A. Rogers

Lockheed Martin Hanford Corp.

K. A. Niemer

Duke Engineering and Services, Inc.

Date Published

May 1999

Prepared for the U.S. Department of Energy

Assistant Secretary for Environmental Management

FLUOR DANIEL HANFORD, INC.
P.O. BOX 1000

Richland, Washington

Hanford Management and Integration Contractor for the

U.S. Department of Energy under Contract DE-AC06-96RL13200 
HNF-3950 Rev. 0

\section{APPROVALS}

Title: Verification and Validation of XSDRNPM Code For Tank Waste Calculations

Prepared by
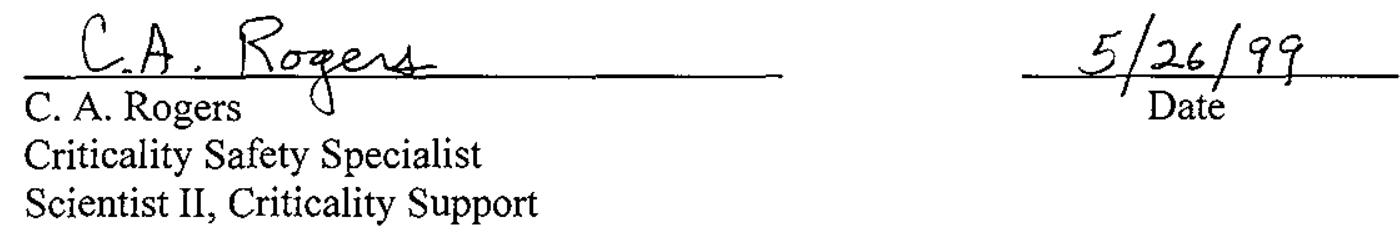

Prepared by:

$\frac{\text { C.A. Rogers for }}{\text { K.A. Niemer, PHD }}$

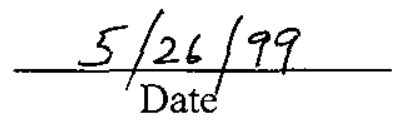

Senior Engineer

Duke Engineering and Services, Inc.

Charlotte, N. C.

Reviewed by: Warrew D. Wittekind

W. D. Wittekind

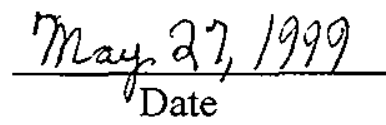

Criticality Safety Specialist

Criticality and Shielding

Fluor Daniel Northwest, Inc.

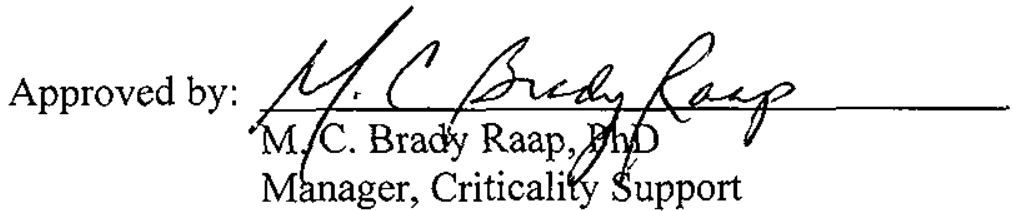

Approved by:

Principal Scientist, Licensing

Approved by:
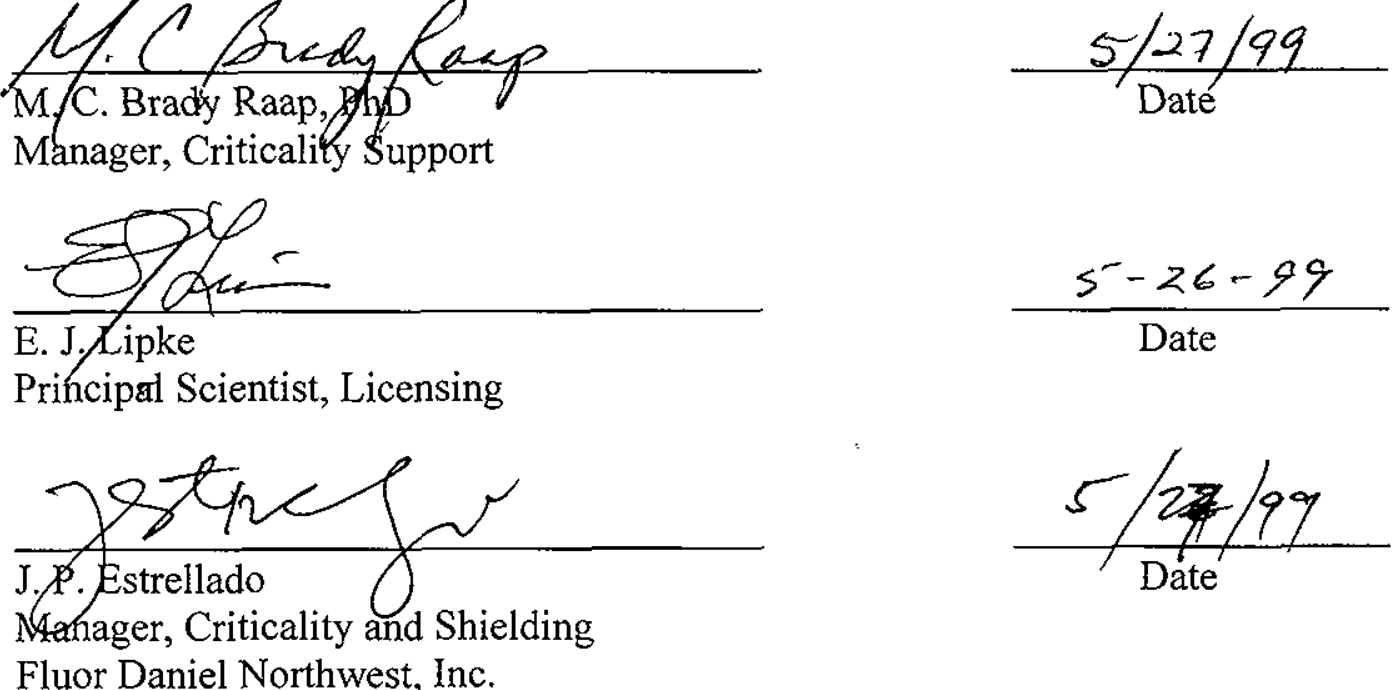
HNF-3950 Rev. 0

This page intentionally left blank 


\section{EXECUTIVE SUMMARY}

This validation study demonstrates that the XSDRNPM computer code accurately calculates $\mathrm{k}_{\infty}$ for water-moderated systems of low enriched uranium, plutonium, and iron. XSDRNPM is contained in the Standardized Computer Analysis for Licensing Evaluation (SCALE-4.3) nuclear criticality safety software for use on a personal computer. Calculations are made on a $200 \mathrm{MHz}$ AST Bravo MS 5200M personal computer using the SCALE 27-group ENDF/B-IV and the SCALE 44-group ENDF/B-V cross-section libraries.

An Upper Safety Limit (USL) is determined that defines the upper bounds on $k_{\text {eff }}$ for acceptable calculations. The USL incorporates an administrative margin of subcriticality of 0.10 , such that an acceptable calculation must not exceed a $\mathrm{k}_{\mathrm{eff}}$ of 0.90 . After taking into account code bias and after subtracting calculational uncertainty at the $95 \%$ confidence level, the USL is found to be 0.881 and 0.882 for the SCALE 27-group ENDF/B-IV and 44-group ENDF/B-V cross section libraries, respectively.

The range of applicability for XSDRNPM calculations is defined by: (1) uranium of any ${ }^{235} \mathrm{U}$ enrichment; (2) plutonium containing up to $20 \mathrm{wt} \%{ }^{240} \mathrm{Pu}$; (3) iron in any proportion; (4) an energy for average lethargy of neutrons causing fissioning (AEF) between 0.029 and $0.344 \mathrm{eV}$; and (5) geometric configurations for which neutron leakage is negligible. When the hydrogen-to-fissile atom $(\mathrm{H} / \mathrm{X})$ ratio falls between 125 and 3694, a system is assured of having an AEF within the range of applicability. Neutron leakage is negligible when the smallest dimension is large enough such that the neutron multiplication constant $\left(\mathrm{k}_{\mathrm{eff}}\right)$ is indistinguishable from the neutron multiplication constant for an unlimited volume $\left(\mathrm{k}_{\infty}\right)$. 


\section{HNF-3950 Rev. 0}

This page intentionally left blank. 


\section{CONTENTS}

3.0 CODE VERIFICATION FOR AST BRAVO 5200M PC ............................................... 3-1

4.0 UPPER SAFETY LIMIT

4.1 REQUIREMENTS TO ESTABLISH SUBCRITICALITY …................................. 4-1

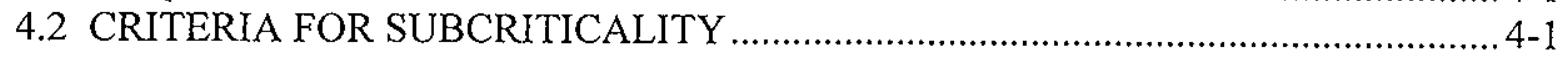

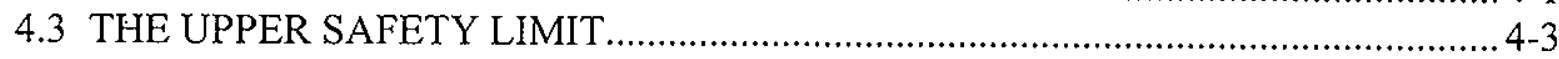

4.3.1 Method 1: Confidence Band with Administrative Margin .................................. 4-4

4.3.2 Method 2: Single-Sided Uniform Width Closed Interval ..................................... 4-6

4.4 APPLICATION OF THE UPPER SAFETY LIMIT ................................................. 4-8

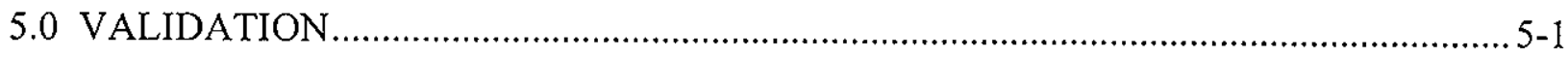

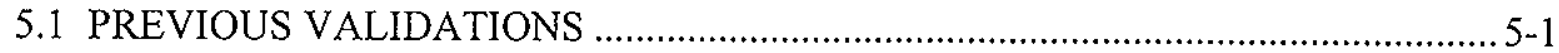

5.1.1 Results Reported in NUREG/CR-6483 …............................................... 5-1

5.1.2 Results Reported in NUREG/CR-6361 ....................................................... 5-3

5.2 RESULTS FROM AST BRAVO 5200M PC CALCULATIONS................................5-3

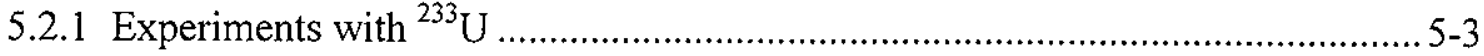

5.2.2 Experiments with Plutonium ……............................................................

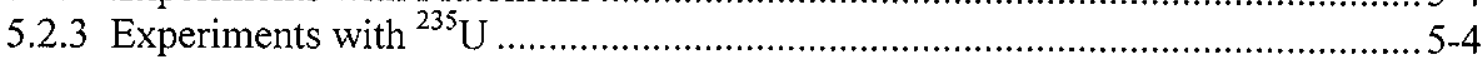

5.2.4 Experiments With Iron...............................................................................

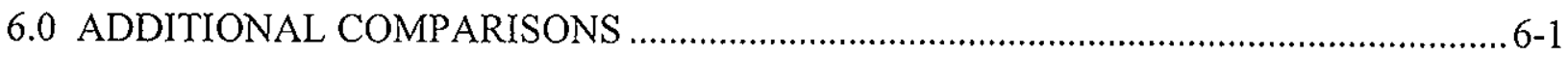

6.1 XSDRNPM AND KENO V.a RESULTS ...............................................................

6.2 COMPARISON BETWEEN CSAS1X AND STANDALONE XSDRNPM............... 6-4

6.3 COMPARISON TO BENCHMARK EXPERIMENTS AND HANDBOOK DATA.. 6-4

6.3.1 Minimum Critical Plutonium Concentration in Water ......................................... 6-4

6.3.2 Comparison to Criticality Handbook Data .......................................................... 6-6

7.0 DISCUSSION

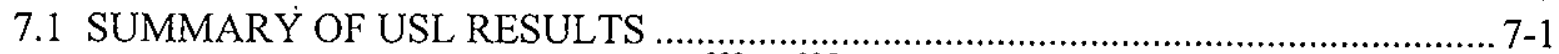

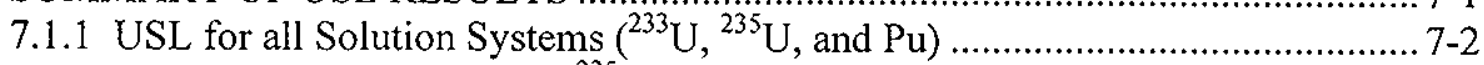

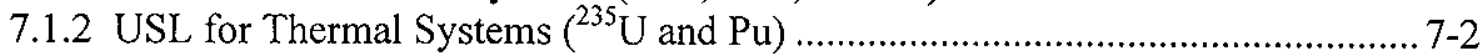

7.1.3 USL for K Basin Sludge Analysis.................................................................. 7-2

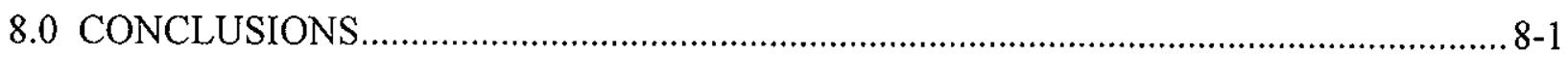

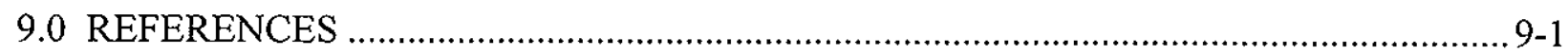


HNF-3950 Rev. 0

APPENDICES

APPENDIX A: SAMPLE STATISTICAL CALCULATION ……...................................... A-1

APPENDIX B: BENCHMARK EXPERIMENTS DESCRIBED IN NUREG/CR-6483 ......... B-1

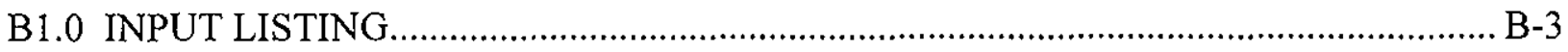

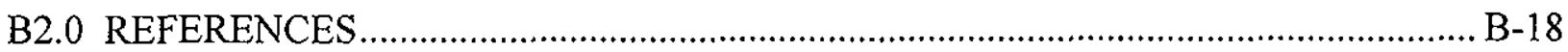

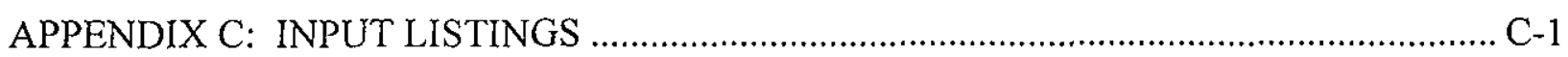

C1.0 INPUT LISTINGS FOR CRITICALITY HANDBOOK COMPARISONS ................... C-3

C1.1 Minimum Critical Plutonium Concentration in Water .......................................... C-3

$\mathrm{C} 1.2 \mathrm{k}_{\infty}$ for Homogeneous $\mathrm{PuO}_{2}$ in Water ....................................................................

$\mathrm{C} 1.3 \mathrm{k}_{\infty}$ for Homogeneous $1.25 \mathrm{wt} \% \mathrm{UO}_{2}$ in Water .................................................... C-5

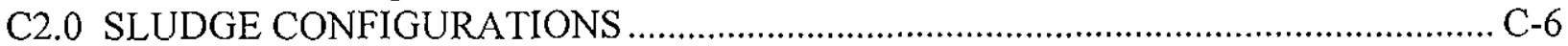

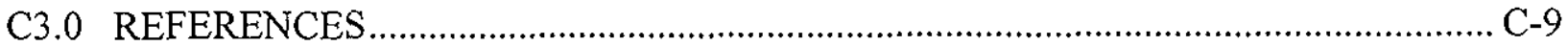

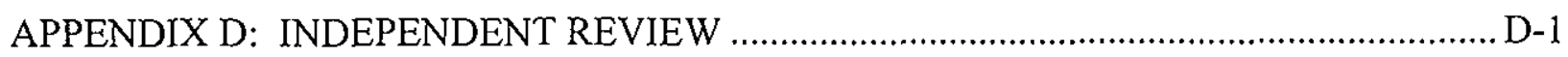

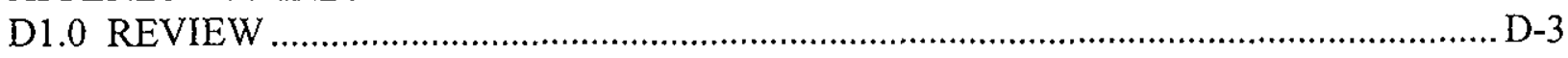

D1.1 Logic of Code Validation...................................................................................

D1.2 Scope of this Independent Peer Review............................................................ D-3

D1.3 Comments on the Validation Report.................................................................. D-4

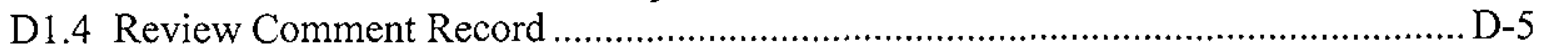


HNF-3950 Rev. 0

\section{LIST OF FIGURES}

3-1. Banner Printed by SCALE-PC Version 4.3 for CSAS 3-4

3-2. Banner Printed by SCALE-PC Version 4.3 for BONAMI. $3-4$

3-3. Banner Printed by SCALE-PC Version 4.3 for NITAWL $3-4$

3-4. Banner Printed by SCALE-PC Version 4.3 for XSDRNPM. $3-5$

3-5. Banner Printed by SCALE-PC Version 4.3 for Standard Composition Library $3-5$

3-6. Banner Printed by SCALE-PC Version 4.3 for 27-Group Cross Section Library $3-5$

3-7. Banner Printed by SCALE-PC Version 4.3 for 44-Group Cross Section Library $3-6$

6-1. $\mathrm{k}_{\infty}$ for Homogeneous $\mathrm{PuO}_{2}$ in Water $6-7$

6-2. Comparison of XSDRNPM with Criticality Handbook for $\mathrm{PuO}_{2}$ in Water........ $6-7$

6-3. XSDRNPM $k_{\infty}$ for Homogeneous $\mathrm{U}(1.25) \mathrm{O}_{2}$ in Water. $6-8$ 
HNF-3950 Rev. 0

\section{LIST OF TABLES}

3-1. Verification Calculations

5-1. XSDRNPM Calculations for ${ }^{233} \mathrm{U}$ Benchmark Experiments........................................... 5-6

5-2. XSDRNPM Calculations for Plutonium Benchmark Experiments .....................................5-7

5-3. XSDRNPM Calculations for Uranium Benchmark Experiments .......................................5-8

5-4. XSDRNPM Calculations for Iron Benchmark Experiments ...........................................5-10

5-5. KENO V.a Calculations for Steel Plate Experiments.................................................... 5-11

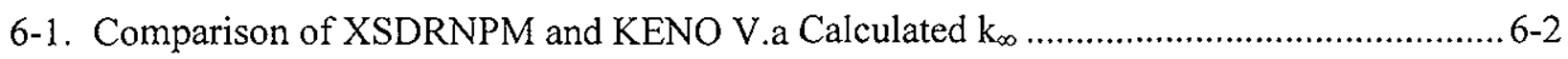

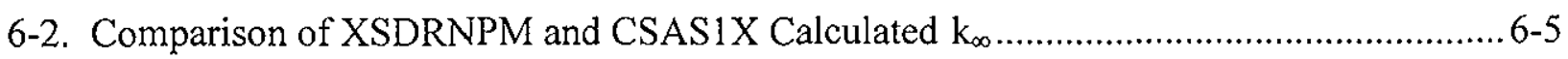

7-1. Summary of Upper Safety Limit Calculations ……........................................................ 
HNF-3950 Rev. 0

\section{LIST OF TERMS}

AEF

AEG

$\mathrm{cm}$

CSAS

CSRL

$\mathrm{Fe}$

$\mathrm{Fe} / \mathrm{HM}$

$\mathrm{g}$

$\mathrm{H} / \mathrm{X}$

$\mathrm{HM}$

$\mathrm{k}_{\mathrm{eff}}$

$\mathrm{k}_{\infty}$

$\mathrm{L}$

LTB

LWR

N/A

PCTR

RSICC

TWRS

USL

wt $\%$ energy of the average lethargy causing fission

average energy group causing fission

centimeter

criticality safety control sequence

criticality safety reference library

iron

mass ratio of iron to heavy metal

grams

hydrogen-to-fissile atom ratio

heavy metal

effective multiplication factor

infinite multiplication factor

liter

lower tolerance band

light water reactor

not applicable

Physical Constants Test Reactor

Radiation Shielding Information Computational Center

Tank Waste Remediation Systems

upper safety limit

weight percent 


\subsection{INTRODUCTION}

This report presents the results of a validation study performed to: (1) demonstrate that the XSDRNPM (Greene and Petrie 1995) computer code may be used to accurately calculate $\mathrm{k}_{\infty}$ for water-moderated systems of enriched uranium, plutonium and iron; (2) establish the subcritical margin in the form of an Upper Safety Limit (USL) for calculations being performed and; (3) clearly define the range of applicability for the validation and subcritical margins.

The XSDRNPM computer code is used to calculate $\mathrm{k}_{\infty}$ for configurations of tank waste in longterm storage at the Hanford Site tank farms. Tank waste is characterized by low concentrations of plutonium mixed with low enriched uranium and a wide variety of neutron absorbing materials. The neutron absorber of greatest interest is iron because of its ability to coprecipitate and to agglomerate with plutonium and uranium.

The sludge type of primary interest in this validation study is $\mathrm{K}$ Basin sludge. This sludge is to be removed from fuel storage basins and is composed of irradiated uranium from $\mathrm{N}$ Reactor fuel elements mixed with basin debris. The plutonium produced by irradiation remains in the uranium. Before disposal at tank farms, iron will be added to provide neutron absorption to ensure compatibility with the technical basis for criticality safety at Hanford tank farms. The calculational model for $\mathrm{K}$ Basin sludge consists of a homogeneous mixture of low enriched uranium, plutonium, iron, and water.

This validation study demonstrates that the XSDRNPM computer code accurately calculates homogenous systems of low enriched uranium and low concentrations of plutonium for simple geometries. The version of XSDRNPM being validated is contained in Version 4.3 of the Standardized Computer Analysis for Licensing Evaluation (SCALE-4.3) nuclear criticality safety software for use on a personal computer (ORNL 1995a). Calculations are made on a $200 \mathrm{MHz}$ AST Bravo MS 5200M personal computer. Validation is performed for both the SCALE 27group ENDF/B-IV and the SCALE 44-group ENDF/B-V cross-section libraries.

Guide to Verification and Validation of the SCALE-4 Criticality Safety Software, NUREG/CR6483 , by Emmett and Jordan (1996) is a primary reference for the method of validation used and is the source of many of the experimental benchmarks calculated. Emmett and Jordan (1996) performed validation calculations for both XSDRNPM and KENO V.a (Petrie and Landers 1995 ) using the SCALE 4.2 code system with the 27-group ENDF/B-IV cross-section library. They performed calculations for ${ }^{233} \mathrm{U},{ }^{235} \mathrm{U},{ }^{239} \mathrm{Pu}$ and ${ }^{240} \mathrm{Pu}$ systems over a broad range of geometries and fuel forms. A subset of these benchmark problems is used as the basis for this validation report.

XSDRNPM calculations for 46 benchmark experiments were performed for this validation. These cases are categorized according to the type of fissile material, and subdivided according to the degree of moderation. Systems most similar to K Basin sludge are those thermal systems with uranium of low enrichment and with a high water content.

An USL is defined as the upper bounds on $\mathrm{k}_{\text {eff }}$ for acceptable calculations. The USL incorporates an administrative margin of subcriticality, any code bias identified in the validation 
process, and calculational uncertainties at the 95 percent confidence level. A primary objective of this validation study is the determination of a USL for the systems being modeled.

Based on evaluation of thermal ${ }^{235} \mathrm{U}$ and Pu systems, subgroupings of these systems, and systems mixed with iron, the USL (with a 0.10 administrative margin) is found to be 0.881 for the 27 -group cross section set and 0.882 for the 44 -group cross section set. These USLs will be valid for XSDRNPM calculations provided the energy of the average lethargy causing fission (AEF) is in the range from 0.029 to $0.344 \mathrm{eV}$. A configuration whose hydrogen-to-fissile atom ratio (H/X) falls between 125 and 3694 is assured of having an AEF within this range of applicability. These values for $\mathrm{AEF}$ and $\mathrm{H} / \mathrm{X}$ define the range of applicability of this validation effort. 
HNF-3950 Rev. 0

\subsection{SCALE CODE PACKAGE DESCRIPTION}

SCALE 4.3 is a collection of modules designed to perform criticality, shielding, and thermal calculations. SCALE 4.3 was obtained from the Radiation Shielding Information Center (RSICC). Calculations were made using compiled executables. The criticality modules are being validated in this report. Functional modules may be run individually or called in a prescribed sequence, designated as a criticality safety control sequence (CSAS). A control sequence is also referred to as a control module. Control sequences that call XSDRNPM end in the letter X. When only a XSDRNPM calculation is needed, the CSAS1X sequence is run.

The functional modules, BONAMI (Greene 1995), NITAWL-II (Greene et al. 1995), and XSDRNPM are used in the CSASIX sequence. Emmett and Jordan provide the following descriptions of these modules:

- BONAMI performs resonance shielding calculations using the Bondarenko shielding factor method. BONAMI reads an AMPX (Greene et al. 1992) master format cross-section library and applies Bondarenko corrections to produce a Bondarenko-corrected master format library. No data processing is performed in BONAMI for the 27-group cross-section library, although it is used with the 44-group library.

- NITAWL-II applies the Nordheim Integral Treatment to perform neutron cross-section processing in the resolved resonance range for $\mathrm{ENDF} / \mathrm{B}$ resonance parameter data. This technique numerically integrates $\mathrm{ENDF} / \mathrm{B}$ resonance parameters using a calculated flux distribution across each resonance and subsequent weighting of the cross-section to the desired broad group structure. NITAWL-II completes the processing of the problemdependent master library from BONAMI. NITAWL-II assembles the group-to-group transfer arrays from the elastic and inelastic scattering components and produces a problemdependent AMPX working format cross-section library for KENO V.a. The analyst specifies resonance parameters based on two options. The first option is for a homogeneous medium in which the resonance region is treated as if the fissile material were in an infinite homogeneous media. The second option is for the fissile material to be treated as a finite lump.

- XSDRNPM is a general purpose, 1-D discrete-ordinates code used for several purposes in SCALE. In the CSASIX criticality sequence, XSDRNPM is used to solve the 1-D Boltzmann equation in slab, cylindrical, or spherical geometry. XSDRNPM can also be run as a standalone code.

The CSAS1X control sequence prepares input for the 3 functional modules described above. User-specified data include the cross-section library, specifications for mixtures, information for resonance region cross-section processing of nuclides (size, geometry, and temperature), and model-specific geometry for the XSDRNPM calculation. Physical and neutronics information not supplied explicitly, but required by the functional modules (such as theoretical density, molecular weights, average resonance region background cross sections), are supplied by the Standard Composition Library or calculated by the Materials Information Processor (Emmet and Jorden 1996). 
The 27-group and 44-group cross section libraries are broad-group libraries collapsed from the 218-group Criticality Safety Reference Library (CSRL) and from the 238-group Library to Analyze Radioactive Waste (LAW), respectively. The 27- and 218-group libraries are based on ENDF/B-IV data, and the 44- and 238-group libraries are based on ENDF/B-V data (ORNL 1995a). 
HNF-3950 Rev. 0

\subsection{CODE VERIFICATION FOR AST BRAVO 5200M PC}

Software verification is the assurance that a computer code correctly performs the operations intended. Verification is usually accomplished by comparing calculated results to known results (e.g. hand calculations, analytical solutions or approximations, or baseline calculations certified by the code developers). Verification demonstrates that software has been properly coded, installed on a computer, and performs the intended functions.

Emmett and Jordan (1996) (NUREG/CR-6483) describe more than 600 benchmark experiment calculations used to provide a comprehensive validation of SCALE-4.2 Criticality Safety Software using the 27-group ENDF/B-IV library. Benchmark experiment descriptions were compiled from three reports: ORNL/CSD/TM-238 (Jordan et al. 1986), ORNL/TM-12374 (Primm 1993), and ORNL/TM-12460 (DeHart and Bowman 1994).

The verification described in this report was performed by executing 46 of the Emmett and Jordan (1996) benchmark calculations on the AST Bravo 5200M PC. Results were compared with NUREG/CR-6483 (Emmett and Jordan 1996) values. The intent of the verification process is to verify that the codes were successfully installed. The acceptance criterion for verification was to execute the test problems with less than 0.5 percent discrepancies in the calculated $\mathrm{k}_{\infty}$ results.

Table 3-1 compares results calculated on the AST Bravo 5200M PC (SCALE 4.3 with the 27-group library) with values from NUREG/CR 6483 (SCALE 4.2 with the 27-group library). The calculated values were found to be in very close agreement with the corresponding NUREG/CR-6483 values. In 13 out of 46 cases, the values agreed to within 0.00001 ( 0.001 percent). In 41 cases agreement is within 0.00050 ( 0.049 percent). Three cases (2110_07, zpr67, and zpr66a) were found to differ by more than 0.00200 ( 0.2 percent). The largest difference for any case was found to be 0.00290 ( 0.283 percent $)$. The exact reason for the differences in results is unknown, but it is thought to result from differences between SCALE-4.2 and SCALE-4.3. The acceptance criterion of $0.5 \%$ is satisfied in all cases. Therefore, the conclusion is that the modules are installed correctly.

Figures 3-1 through 3-7 list the banner information printed by SCALE-PC version 4.3 for execution of CSAS, BONAMI, NITAWL, XSDRNPM, and the libraries, respectively. Banners contained the statement: "This is not a SCALE-PC configuration controlled code." Normally, this statement is not printed. It was printed for this evaluation because the location of executable files on the hard drive did not match the location indicated in the quality assurance table (i.e., file QATABLE). This discrepancy developed when program files were moved from the $\mathrm{D}$ drive to the $C$ drive without updating QATABLE. Cases run with the correct drive specified in QATABLE did not print this statement. This discrepancy does not affect calculations made by the codes. 
Table 3-1. Verification Calculations. (2 sheets)

\begin{tabular}{|c|c|c|c|c|}
\hline Case & $\begin{array}{c}\text { NUREG/CR-6483 } \\
k_{\infty}\end{array}$ & $\begin{array}{c}\text { AST Bravo } \\
\mathrm{k}_{\infty}\end{array}$ & $\begin{array}{l}\text { Absolute } \\
\text { Difference }\end{array}$ & $\begin{array}{c}\text { Percent } \\
\text { Difference }\end{array}$ \\
\hline 111_20 & 1.01417 & 1.01400 & 0.00017 & 0.017 \\
\hline $111 \_25$ & 1.02694 & 1.02686 & 0.00008 & 0.008 \\
\hline $172 \overline{7} 01$ & 0.96717 & 0.96713 & 0.00004 & 0.004 \\
\hline $1727 \_02$ & 0.98106 & 0.98107 & 0.00001 & 0.001 \\
\hline $1727 \_03$ & 0.97929 & 0.97928 & 0.00001 & 0.001 \\
\hline $1727 \_04$ & 0.97601 & 0.97600 & 0.00001 & 0.001 \\
\hline $1727 \_05$ & 0.97674 & 0.97669 & 0.00005 & 0.005 \\
\hline $1727 \_06$ & 0.97641 & 0.97634 & 0.00007 & 0.007 \\
\hline $1727 \_07$ & 0.99629 & 0.99619 & 0.00010 & 0.010 \\
\hline $1727-08$ & 0.98401 & 0.98395 & 0.00006 & 0.006 \\
\hline 172709 & 1.00709 & 1.00800 & 0.00091 & 0.090 \\
\hline $1727 \_10$ & 1.00112 & 1.00113 & 0.00001 & 0.001 \\
\hline $1727 \_14$ & 0.97630 & 0.97626 & 0.00004 & 0.004 \\
\hline $1727 \_15$ & 0.98259 & 0.98256 & 0.00003 & 0.003 \\
\hline $2109 \_25$ & 1.01055 & 1.01053 & 0.00002 & 0.002 \\
\hline 2110_01 & 1.00486 & 1.00487 & 0.00001 & 0.001 \\
\hline $2110 \_02$ & 1.01617 & 1.01567 & 0.00050 & 0.049 \\
\hline $2110 \_03$ & 1.01669 & 1.01722 & 0.00053 & 0.052 \\
\hline $2110 \_04$ & 1.01852 & 1.01751 & 0.00101 & 0.099 \\
\hline 2110_07 & 1.01999 & 1.01712 & 0.00287 & 0.281 \\
\hline $2110 \_30$ & 1.01804 & 1.01845 & 0.00041 & 0.040 \\
\hline $2110 \_32$ & 1.01618 & 1.01653 & 0.00035 & 0.034 \\
\hline BAPL1 & 1.00883 & 1.00928 & 0.00045 & 0.045 \\
\hline BAPL2 & 1.01266 & 1.01302 & $0.000 \overline{36}$ & 0.036 \\
\hline BAPL3 & 1.01471 & 1.01498 & 0.00027 & 0.027 \\
\hline BIG10 & 1.00153 & 1.00153 & 0.00000 & 0.000 \\
\hline FLAT 25 & 1.00885 & 1.00885 & 0.00000 & 0.000 \\
\hline GODIVA & 1.00622 & 1.00622 & 0.00000 & 0.000 \\
\hline $\mathrm{H} 2 \mathrm{OX} 1$ & 1.00869 & 1.00875 & 0.00006 & 0.006 \\
\hline HI240R & 1.00417 & 1.00435 & 0.00018 & 0.018 \\
\hline JEZB23 & 0.96475 & 0.96475 & 0.00000 & 0.000 \\
\hline ORNL1 & 0.99804 & 0.99832 & 0.00028 & 0.028 \\
\hline ORNL10 & 0.99592 & 0.99592 & 0.00000 & 0.000 \\
\hline ORNL2 & 0.99788 & 0.99788 & 0.00000 & 0.000 \\
\hline ORNL3 & 0.99492 & 0.99492 & 0.00000 & 0.000 \\
\hline ORNL4 & 0.99644 & 0.99644 & 0.00000 & 0.000 \\
\hline
\end{tabular}


Table 3-1. Verification Calculations. (2 sheets)

\begin{tabular}{|c|c|c|c|c|}
\hline Case & $\begin{array}{c}\text { NUREG/CR-6483 } \\
k_{\infty}\end{array}$ & $\begin{array}{c}\text { AST Bravo } \\
k_{\infty}\end{array}$ & $\begin{array}{c}\text { Absolute } \\
\text { Difference }\end{array}$ & $\begin{array}{c}\text { Percent } \\
\text { Difference }\end{array}$ \\
\hline PNL3 & 1.00057 & 1.00059 & 0.00002 & 0.002 \\
\hline PNL6B & 1.01678 & 1.01657 & 0.00021 & 0.021 \\
\hline TRX1 & 1.01237 & 1.01341 & 0.00104 & 0.103 \\
\hline TRX2 & 1.01804 & 1.01868 & 0.00064 & 0.063 \\
\hline ÜH3NI & 1.06144 & 1.06137 & 0.00007 & 0.007 \\
\hline$\overline{\mathrm{UH}} 3 \mathrm{UR}$ & 1.02171 & 1.02183 & 0.00012 & 0.012 \\
\hline ZPR311 & 1.00693 & 1.00688 & 0.00005 & 0.005 \\
\hline ZPR312 & 1.01285 & 1.01261 & 0.00024 & 0.024 \\
\hline ZPR66A & 1.01792 & 1.01554 & 0.00238 & 0.234 \\
\hline ZPR67 & 1.02638 & 1.02348 & 0.00290 & 0.283 \\
\hline \multicolumn{3}{|c|}{ Avaerage } & 0.00036 & 0.035 \\
\hline \multicolumn{3}{|c|}{ Maximum } & 0.00290 & 0.283 \\
\hline
\end{tabular}

Note: $\quad{ }^{1}$ Emmett and Jordan (1996), calculations performed using SCALE 4.2.

${ }^{2}$ TWRS calculations performed using SCALE 4.3. 
HNF-3950 Rev. 0

Figure 3-1. Banner Printed by SCALE-PC Version 4.3 for CSAS.

\begin{tabular}{|c|c|c|}
\hline \multicolumn{3}{|c|}{ PROGRAM VERIFICATION INFORMATION } \\
\hline CODE SYSTEM: & SCALE-PC VERSION: & 4.3 \\
\hline PROGRAM: & CSAS & \\
\hline CREATION DATE: & $3-08-96$ & \\
\hline VOLUME: & CROOT & \\
\hline LIBRARY: & C:ISCALE43\EXE & \\
\hline THIS IS NOT A S & CONFIGURATION C & LLED CODE $^{1}$ \\
\hline
\end{tabular}

${ }^{1}$ This is printed because the hard drive, where files are stored (i.e., drive $C$ ), does not match the drive designated shown in the quality assurance tables (i.e., drive D). This discrepancy does not affect the calculations.

Figure 3-2. Banner Printed by SCALE-PC Version 4.3 for BONAMI

\begin{tabular}{|c|c|c|}
\hline \multicolumn{3}{|c|}{ PROGRAM VERIFICATION INFORMATION } \\
\hline CODE SYSTEM: & SCALE-PC VERSION: & 4.3 \\
\hline PROGRAM: & O0O008 $8^{i}$ or BONAMI & \\
\hline CREATION DATE: & $9-15-95$ & \\
\hline VOLUME: & CROOT & \\
\hline LIBRARY: & C:ISCALE43\EXE & \\
\hline THIS IS NOT A SCA & CONFIGURATION CO & LLED CODE $^{2}$ \\
\hline
\end{tabular}

${ }^{l}$ Numeric identifier used when executed through CSAS, alphabetic identifier used when executed individually.

${ }^{2}$ See note for Figure 3-1.

Figure 3-3. Banner Printed by SCALE-PC Version 4.3 for NITAWL.

\begin{tabular}{|c|c|c|}
\hline \multicolumn{3}{|c|}{ PROGRAM VERIFICATION INFORMATION } \\
\hline CODE SYSTEM: & SCALE-PC VERSION: & 4.3 \\
\hline PROGRAM: & O0O002 1 or NITAWL & \\
\hline CREATION DATE: & $9-28-95$ & \\
\hline VOLUME: & CROOT & \\
\hline LIBRARY: & C:ISCALE43\EXE & \\
\hline THIS IS NOT AS & CONFIGURATION CO & ROLLED CODE ${ }^{2}$ \\
\hline
\end{tabular}

${ }^{1}$ Numeric identifier used when executed through CSAS, alphabetic identifier used when executed individually.

${ }^{2}$ See note for Figure 3-1. 
HNF-3950 Rev. 0

Figure 3-4. Banner Printed by SCALE-PC Version 4.3 for XSDRNPM .

\begin{tabular}{|c|c|c|}
\hline \multicolumn{3}{|c|}{ PROGRAM VERIFICATION INFORMATION } \\
\hline CODE SYSTEM: & SCALE-PC VERSION: & 4.3 \\
\hline PROGRAM: & O0O001 $1^{1}$ or XSDRN & \\
\hline CREATION DATE: & $9-28-95$ & \\
\hline VOLUME: & CROOT & \\
\hline LIBRARY: & C:ISCALE43\EXE & \\
\hline THIS IS NOT A & CONFIGURATION C & OLLED CODE ${ }^{2}$ \\
\hline
\end{tabular}

${ }^{1}$ Numeric identifier used when executed through CSAS, alphabetic identifier used when executed individually.

${ }^{2}$ See note for Figure 3-1.

Figure 3-5. Banner Printed by SCALE-PC Version 4.3 for Standard Composition Library.

\section{STANDARD COMPOSITION LIBRARY DATA}

UNIT NUMBER: $\quad 89$

DATASET NAME: C:Iscale43\DATALIB\FT89F001

LIBRARY TITLE: SCALE-4 STANDARD COMPOSITION LIBRARY

637 STANDARD COMPOSITIONS, 490 NUCLIDES

90 ELEMENTS WITH VARIABLE ISOTOPIC

DISTRIBUTIONS

CREATION DATE: 6/30/95

Figure 3-6. Banner Printed by SCALE-PC Version 4.3 for 27 -Group Cross Section Library.

\section{CROSS SECTION LIBRARY DATA}

UNIT NUMBER: $\quad 82$

DATASET NAME: C:Iscale43\DATALIB\FT82F001

LIBRARY TITLE: SCALE 4.2-27 GROUP NEUTRON GROUP LIBRARY

BASED ON ENDF-B VERSION 4 DATA

COMPILED FOR NRC: $\quad 1 / 27 / 89$

LAST UPDATED: $\quad 8 / 12 / 94$

L. M. PETRIE - ORNL 
HNF-3950 Rev. 0

Figure 3-7. Banner Printed by SCALE-PC Version 4.3 for 44-Group Cross Section Library.

\begin{tabular}{|ll|}
\hline CROSS SECTION LIBRARY DATA \\
\hline & \\
UNIT NUMBER: & 83 \\
DATASET NAME: & C:Iscale43IDATALIBIFT83F001 \\
LIBRARY TITLE: & scale 4.3 - 44 neutron group library \\
& based on endf-b version 5 data \\
& collapsed with a light water reactor cell flux spectrum from 238 \\
& groups \\
& compiled for nrc: $\quad 9 / 01 / 94$ \\
& last updated: $\quad 5 / 14 / 96$ \\
& m. d. dehart \& $1 . \mathrm{m}$. petrie nuclear eng. appl. - cped - ornl \\
\hline
\end{tabular}


HNF-3950 Rev. 0

\subsection{UPPER SAFETY LIMIT}

Software validation is the assurance that a model as embodied in a computer code is a correct representation of the process or system for which it is intended. This is usually accomplished by comparing code results to either physical data or a validated code designed to perform the same type of analysis. Validation is the process of demonstrating that the software predicts "correct" results for the "systems for which it is intended." The validation process uses critical experiment models covering the applicable range of system parameters.

\subsection{REQUIREMENTS TO ESTABLISH SUBCRITICALITY}

To establish that a system or process will be subcritical under all normal and credible abnormal conditions, it is necessary to establish acceptable subcritical limits. DOE Standard 3007-93, Guidelines for Preparing Criticality Safety Evaluations at DOE Non-Reactor Facilities, (DOE 1993 ) lists four acceptable methods for establishing subcritical limits:

- By reference to national standards that present subcritical limits.

- By reference to widely accepted handbooks of subcritical limits.

- By reference to experiments with appropriate adjustments to ensure subcriticality when the uncertainties of parameters reported in the experiment documentation are considered.

- By validated calculational techniques.

Hanford Site requirements for validation of analysis methods are found in HNF-PRO-539, Criticality Safety Evaluations (FDH 1997b). A code used for criticality safety evaluation is required to be appropriate for the complexity of the problem, be validated, and be identified by code version and date last modified. In addition, each neutron cross section set used for calculations must be properly identified and must be validated in conjunction with validation of the criticality code. The analyst using the code to perform criticality safety calculations must demonstrate sufficient familiarity with the code and the cross section libraries used. The validation report must show comparison with known critical and/or subcritical systems.

\subsection{CRITERIA FOR SUBCRITICALITY}

American National Standard ANSI/ANS-8.1 (ANS 1983) requires a determination of the calculational bias by "correlating the results of criticality experiments with results obtained for these same systems by the method being validated." The analyst shall use "sufficient correlation to determine if major changes in the bias can occur over the range of variables in the operation being analyzed. Where the extrapolation is large, supplement the method with other calculation methods to provide a better estimate of the bias in the extended area."

American National Standard ANSI/ANS-8.17 (ANS 1994), Section 5.1, provides the following criteria to establish subcriticality: 
Where methods of analysis are used to predict neutron multiplication factors, the calculated multiplication factor, $\mathrm{k}_{s}$, shall be equal to or less than an established allowable neutron multiplication factor:

$$
\mathrm{k}_{\mathrm{s}} \leq \mathrm{k}_{\mathrm{c}}-\Delta \mathrm{k}_{\mathrm{s}}-\Delta \mathrm{k}_{\mathrm{c}}-\Delta \mathrm{k}_{\mathrm{m}}
$$

where

$\mathrm{k}_{\mathrm{s}}=$ the calculated allowable maximum multiplication factor, $\mathrm{k}_{\mathrm{eff}}$, of the system being evaluated for all normal or credible abnormal conditions or events.

$k_{c}=$ the mean $k_{\text {eff }}$ that results from the calculation of benchmark criticality experiments using a particular calculational method. If the calculated $\mathrm{k}_{\mathrm{eff}} \mathrm{S}$ for the criticality experiments exhibit a trend with a parameter, then $\mathrm{k}_{\mathrm{c}}$ shall be determined by extrapolation on the basis of a best fit to the calculated values. The criticality experiments used as benchmarks in computing $k_{c}$ should have physical compositions, configurations, and nuclear characteristics (including reflectors) similar to those of the system being evaluated.

$\Delta \mathrm{k}_{\mathrm{s}}=$ uncertainty in the value of $\mathrm{k}_{\mathrm{s}}$

$\Delta \mathrm{k}_{\mathrm{c}}=$ uncertainty in the value of $\mathrm{k}_{\mathrm{c}}$

$\Delta \mathrm{k}_{\mathrm{m}}=$ an arbitrary administrative margin to ensure the subcriticality of $\mathrm{k}_{s}$.

Sources of uncertainty which determine $\Delta \mathrm{k}_{\mathrm{s}}$ include:

(a) statistical and/or convergence uncertainties

(b) material and fabrication tolerances

(c) limitations in the geometric and/or material representations used.

Sources of uncertainty which determine $\Delta \mathrm{k}_{\mathrm{c}}$ include:

(a) uncertainties in critical experiments

(b) statistical and/or convergence uncertainties in the computation

(c) extrapolation outside of the range of experimental data

(d) limitations in the geometric and/or material representations used.

HNF-PRO-537 (FDH 1997a) establishes the following minimum subcritical limit criteria:

- If reliable experimental data are available for closely similar systems and adequate calculational techniques exist for relatively small extrapolations of the data, the $\mathrm{k}_{\mathrm{eff}}$ of spheres and cylinders must not exceed 0.98 and the $k_{\text {eff }}$ of slabs must not exceed 0.97 . The $\mathrm{k}_{\text {eff }}$ of complicated geometries must not exceed 0.95 . 
- If limited experimental data exist for a similar system and relatively large but reasonable interpolations or extrapolations are necessary, the calculated $\mathrm{k}_{\mathrm{eff}}$ of the system must not exceed 0.95 .

- If no applicable experimental data are available, such that calculations must be based on very large extrapolations from experimental data, the calculated $\mathrm{k}_{\text {eff }}$ of the system must not exceed 0.90 .

Subcritical limits will be established for evaluation of K Basin sludge in the Hanford Site Tank Farms by validating the calculational techniques.

\subsection{THE UPPER SAFETY LIMIT}

An assurance of subcriticality requires the determination of an acceptable margin based on known biases and uncertainties. The Upper Safety Limit (USL) is defined as the upper bounds for an acceptable calculation.

Critical benchmark experiments used to determine calculational bias ( $\beta$ ) should be similar in composition, configuration, and nuclear characteristics to the system under examination. The range of applicability may be extended beyond the range of conditions represented by the benchmark experiments by extrapolating the trends established for the bias. For critical systems $\beta$ is related to $\mathrm{k}_{\mathrm{c}}$ as follows:

$$
\begin{aligned}
& \beta=\mathrm{k}_{\mathrm{c}}-1 \\
& \Delta \beta=\Delta \mathrm{k}_{\mathrm{c}} .
\end{aligned}
$$

Using this definition of bias, the condition for subcriticality is rewritten as:

$$
\mathrm{k}_{\mathrm{s}}+\Delta \mathrm{k}_{\mathrm{s}} \leq 1-\Delta \mathrm{k}_{\mathrm{m}}+\beta-\Delta \beta
$$

A system is acceptably subcritical if a calculated $k_{\text {eff }}$ plus calculational uncertainties lies at or below the USL.

$$
\mathrm{k}_{\mathrm{s}}+\Delta \mathrm{k}_{\mathrm{s}} \leq \mathrm{USL}
$$

The USL can be written as:

$$
\mathrm{USL}=1-\Delta \mathrm{k}_{\mathrm{m}}+\beta-\Delta \beta
$$

Bias is negative if $k_{c}<1$ and positive if $k_{c}>1$. For conservatism a positive bias is set equal to zero for the purpose of defining the USL. $\Delta \beta$ is determined at the 95 percent confidence level.

The USL takes into account bias, uncertainties, and administrative and/or statistical margins such that the calculated configuration will be subcritical with a high degree of confidence. 
$\beta$ is related to system parameters and may not be constant over the range of a parameter of interest. If $\mathrm{k}_{\mathrm{eff}} \mathrm{s}$ for benchmark experiments vary as a function of a system parameter, such as enrichment or degree of moderation, then $\beta$ can be determined from a best fit as a function of the parameter upon which it is dependent. Extrapolation outside the range of validation must take into account trends in the bias.

Both $\Delta \beta$ and $\beta$ can vary with a given parameter, and the USL is typically expressed as a function of the parameter. The most important system parameter which affect bias is the degree of moderation of the neutrons. This parameter can be expressed in several different ways, such as the neutron energy of the average lethargy causing fission (AEF), average energy group (AEG), or hydrogen-to-fissile atom $(\mathrm{H} / \mathrm{X})$ ratio.

Generally, the "bias" can be broken down into components caused by system modeling error, code modeling inaccuracies, cross-sectional inaccuracies, and so forth. Biases associated with individual inaccuracies are usually combined into a total bias to represent the combined effect from all sources that prevent code and cross-sections from calculating the experimental value of $\mathrm{k}_{\text {eff. }}$

One or two calculations are insufficient to determine calculational bias. In practice, it is necessary to determine the "average bias" for a group of experiments. A statistical analysis of the variation of biases around this average value is used to establish an uncertainty associated with the bias value when it is applied to a future calculation of a similar critical system. The lower limit of this band of uncertainty establishes an upper bound for which a future calculation of $\mathrm{k}_{\mathrm{eff}}$ for a similar critical system can be considered subcritical with a high degree of confidence.

Lichtenwalter et al. (1997) discusses two methods of determining the USL from the bias and uncertainties associated with calculations. The first method applies a statistical calculation of the bias and its uncertainty plus an administrative margin to a linear fit of critical experimental benchmark data. The second method applies a statistical calculation to determine a combined lower confidence band and subcritical margin. Both methods assume that the distribution of data points is normal. The following discussion of each method follows Lichtenwalter et al. (1997) very closely, and is based on equations and techniques described in Dyer et al. (1991), Easter (1985), Bowden and Graybill (1966), Johnson (1968), and Cain (1995).

\subsubsection{Method 1: Confidence Band with Administrative Margin}

USL Method 1 applies a statistical calculation of the bias and its uncertainty plus an administrative margin to a linear fit of critical experiment benchmark data. A lower confidence band is statistically determined based on the existing data and a specified level of confidence. The width of the confidence band, W, is strongly influenced by the standard deviation in the data and the confidence level desired. This confidence band, accounts for uncertainties in the experiments, the calculational approach, and in calculational data (e.g., cross sections), and is therefore a statistical basis for $\Delta \beta$, the uncertainty in the value of $\beta$. When $\gamma_{1}$ is the specified margin of confidence, $W$ is defined for a confidence level of $\left(1-\gamma_{1}\right)$ using the relationship

$$
W=\max \left\{w(x) \mid x_{\min , x \max }\right\}
$$


where $w(x)$ is the confidence band on the linear regression for a "single future calculation" expressed as

$$
w(x)=t_{1-y_{1}, s_{p}}\left[1+\frac{1}{n}+\frac{(x-\bar{x})^{2}}{\sum_{i=l, n}\left(x_{i}-\bar{x}\right)^{2}}\right]^{\frac{1}{2}},
$$

and

$n=$ the number of critical calculations used in establishing $\mathrm{k}_{\mathrm{c}}(\mathrm{x})$

$t_{1-y_{1}}=$ the Student $-\mathrm{t}$ distribution for $1-\gamma_{1}$ and $\mathrm{n}-2$ degrees of freedom

$\bar{x}=$ the mean value of parameter $\mathrm{x}$ in the set of calculations

$s_{p}=$ the pooled standard deviation for the set of criticality calculations.

For simplicity, it is desirable to obtain a constant width margin. Hence, for conservatism, the confidence band width $\mathrm{W}$ is defined as the maximum of $\left(w\left(x_{\min }\right), w\left(x_{\max }\right)\right)$, where $x_{\min }$ and $x_{\max }$ are the minimum and maximum values of the independent parameter $x$, respectively. Typically, $\mathrm{W}$ is determined at a 95 percent confidence level.

The pooled standard deviation is obtained from the pooled variance $\left(s_{p}=\sqrt{s_{p}^{2}}\right)$, where $s_{p}$ is given as:

$$
S_{p}^{2}=S_{k(x)}^{2}+S_{w}^{2}
$$

where $S_{k(x)}^{2}$ is the variance (or mean square error) of the regression fit, and is given by:

$$
s_{k(x)}^{2}=\frac{1}{(n-2)}\left[\sum_{i=1, n}\left(k_{i}-\bar{k}\right)^{2}-\frac{\left\{\sum_{i=1, n}\left(x_{i}-\bar{x}\right)\left(k_{i}-\bar{k}\right)\right\}^{2}}{\sum_{i=1, n}\left(x_{i}-\bar{x}\right)^{2}}\right]
$$

and $S_{w}^{2}$ is the within-variance of the data:

$$
s_{w}^{2}=\frac{1}{n} \sum_{i=1, n} \sigma_{i}^{2}
$$

where $\sigma_{i}$ is the standard deviation associated with the convergence of $k_{i}$ for a Monte Carlo calculation. It is recommended that the individual standard deviations for Monte Carlo 
calculations be roughly uniform in value for the best results. For deterministic codes that do not have a standard deviation associated with a computed value of $\mathrm{k}$, the standard deviation is zero.

In USL Method $1, \Delta \mathrm{k}_{\mathrm{m}}$ is an arbitrary administrative value. HNF-PRO-537 (FDH 1997a) requires the selection of a minimum of $\Delta \mathrm{k}_{\mathrm{m}}$, to depend on the similarity and adequacy of the benchmark data. Based on this criterion, $\Delta \mathrm{k}_{\mathrm{m}}$ may range from 0.02 to 0.10 compared with the configuration being evaluated.

Having determined the constant $W$ and substituting for $\Delta \beta$ in Equation 6 , the expression for the USL based on Method 1 may be written as:

$$
\mathrm{USL}_{1}(\mathrm{x})=1.0-\Delta \mathrm{k}_{\mathrm{m}}-\mathrm{W}+\beta(\mathrm{x}) \text {. }
$$

\subsubsection{Method 2: Single-Sided Uniform Width Closed Interval}

USL Method 2, sometimes referred to as a lower tolerance band (LTB) method, applies statistical techniques to determine a combined lower confidence band plus subcritical margin. This differs from USL Method 1 in which $\Delta \mathrm{k}_{\mathrm{m}}$ and $\Delta \beta$ are determined independently.

The purpose of this method is to determine a uniform tolerance band over a specified closed interval for a linear least-squares model. The level of confidence in the limit being calculated is $\alpha$ and is typically in the range from 0.90 to 0.999 .

The USL based on Method 2 is defined as

$$
\mathrm{USL}_{2}(\mathrm{x})=1.0-\left(C_{\alpha / P} \cdot s_{p}\right)+\beta(\mathrm{x})
$$

where $s_{p}$ is the pooled variance of $\mathrm{k}_{\mathrm{c}}$ described earlier. The term $C_{\alpha / P} \cdot s_{p}$ provides a band for which there is a probability $P$ with a confidence $\alpha$ that an additional calculation of $\mathrm{k}_{\mathrm{eff}}$ for a critical system will lie within the band. For example, a $C_{95 / 99.5}$ multiplier produces a USL for which there is a 95 percent confidence that 995 out of 1000 future calculations of critical systems will yield a value of $\mathrm{k}_{\mathrm{eff}}$ above the USL.

The analysis is over the closed interval from $x=a$ to $x=b . C_{\alpha / P}$ is calculated according to the following equations:

$$
C_{\alpha / P}=C^{*}+z_{p} \cdot \sqrt{\frac{n-2}{\chi^{2}}}
$$

where

$z_{p}$ is the Student $t$ statistic depending on $n$ and $P$

$\chi^{2}$ is the chi square distribution, a function of $n-2$ and $a$.

$\mathrm{C}^{*}$ is determined using the following parameters: 


$$
\begin{gathered}
g=\sqrt{\frac{1}{n}+\frac{(a-\bar{x})^{2}}{\sum_{i=1}^{n}\left(x_{i}-\bar{x}\right)^{2}}} \\
h=\sqrt{\frac{1}{n}+\frac{(b-\bar{x})^{2}}{\sum_{i=1}^{n}\left(x_{i}-\bar{x}\right)^{2}}} \\
\rho=\frac{1}{g h} \cdot\left\{\begin{array}{c}
\frac{1}{n}+\frac{(a-\bar{x})(b-\bar{x})}{\sum_{i=1}^{n}\left(x_{i}-\bar{x}\right)^{2}}
\end{array}\right\} \\
A=\frac{g}{h}
\end{gathered}
$$

For values of $A$ between 0.5 and $1.5(0.5 \leq A \leq 1.5)$ the value of $\rho$ determined from the above formula is used to obtain a value for D from Table 3 in Bowden (1966), and

$$
\mathrm{C}^{*}=\mathrm{D} \cdot \mathrm{g} .
$$

When $A$ is outside the above range, $A$ is replaced by $l / A$ for the determination of $D$, and $C^{*}$ is given by

$$
C^{*}=\mathrm{D} \cdot \mathrm{h} .
$$

This approach provides a statistically based subcritical margin, $\Delta \mathrm{k}_{\mathrm{m}}$, which can be determined as the difference $\left(C_{\alpha / P} \cdot s_{p}\right)-W$. In criticality safety applications, such a statistically determined approach generally serves to illustrate the adequacy of the administrative margin. It is recommended that Method 2 be applied in tandem with Method 1 to verify that the administrative margin is conservative relative to a purely statistical basis. This concurrent application of Method 2 is especially important when a limited number of data points are used in the determination of $\mathrm{k}_{\mathrm{c}}(\mathrm{x})$, or when the calculated values have a large standard deviation. In these cases, a larger value of the statistically based subcritical margin may indicate the need for a larger administrative margin.

Lichtenwalter et al. (1997) documents a computer program called USLSTATS that was developed to perform the required statistical analysis and calculate USLs based on Methods 1 and 2 (see Appendix A). 
HNF-3950 Rev. 0

\subsection{APPLICATION OF THE UPPER SAFETY LIMIT}

The equations USL for Methods 1 and 2 (Equations 12 and 13) represent an upper bound to assure subcriticality for a given configuration when the calculated $k_{\text {eff }}$ plus uncertainty for the configuration is less than the USL. An USL may be determined as a function of any one of a number of independent parameters. When more than one USL is determined, the subcritical limit is chosen as the smallest from among the possible USLs.

For a given parameter, the USL is valid over the range of that parameter in the set of calculations used to determine the USL. However, ANSI/ANS-8.1 (ANS 1983) allows the range of applicability to be extended beyond this range by extrapolating the trends established for the bias. No precise guidelines are specified for the limits of extrapolation. Thus, engineering judgement should be applied when extrapolating beyond the range of the parameter bounds. 


\subsection{VALIDATION}

A criticality safety evaluation of long-term storage in large underground tanks of sludge removed from the floor of large water storage basins located in the 100-K Areas on the Hanford Site has been undertaken. For the purpose of calculating $\mathrm{k}_{\infty}$, a model of $\mathrm{K}$ Basin sludge was developed for input into the XSDRNPM code. This sludge model is composed of irradiated low enriched uranium mixed with iron and water. Plutonium generated during irradiation of uranium is assumed to remain associated with the uranium. The highest ${ }^{235} \mathrm{U}$ enrichment possible in sludge uranium is $1.25 \mathrm{wt} \%$, the enrichment in unirradiated uranium. During irradiation the ${ }^{235} \mathrm{U}$ enrichment decreased, and much of the actual uranium in this sludge is depleted with ${ }^{235} \mathrm{U}$ content as low as $0.60 \mathrm{wt} \%$. However during the irradiation process the plutonium content increased to as much as $0.30 \mathrm{wt} \%$ of the uranium. Evaluation of this sludge requires that calculations be made over the range of possible combinations of these waste components.

The plutonium used in the sludge model is composed of ${ }^{239} \mathrm{Pu}$ and ${ }^{240} \mathrm{Pu}$. Although other isotopes are present, they are of lesser importance to criticality safety and are not taken into account explicitly in calculations. Isotopes not specifically identified in the model are treated as if they were ${ }^{239} \mathrm{Pu}$ or ${ }^{240} \mathrm{Pu}$. The ${ }^{240} \mathrm{Pu}$ content might be as high as $16 \mathrm{wt} \%$ of the plutonium.

Iron is added to sludge to ensure long term chemical compatibility and subcriticality. The iron content is specified in terms of the ratio of its mass to the mass of uranium (i.e., the Fe/U mass ratio), and this ratio is expected to exceed 0.70 . This means that the $\mathrm{Fe} / \mathrm{Pu}$ and the $\mathrm{Fe} /{ }^{235} \mathrm{U}$ mass ratios will exceed 200. No restriction is placed upon the water content. Although calculation of $\mathrm{k}_{\infty}$ is made over the entire range of possible water concentration, the configuration of interest to criticality safety is that which results in the largest $\mathrm{k}_{\infty}$.

Basically, tank wastes modeled in this validation are characterized by low concentration of plutonium mixed with low enriched uranium and with iron as a neutron absorbing material. This section describes previously published benchmarking results and the results from current TWRS (AST Bravo 5200M PC) benchmarking calculations. Experiments are chosen for calculation based upon their possessing isotopes characteristic of tank waste and upon other physical similarities.

\subsection{PREVIOUS VALIDATIONS}

Several documents providing detailed guidance for the validation of the SCALE code system and the validation of SCALE for general use have been published. This section presents results from two such reports for benchmark experiments applicable to this validation effort.

\subsubsection{Results Reported in NUREG/CR-6483}

Emmett and Jordan (1996) describe more than 600 benchmark experiment calculations used to provide a comprehensive validation of the SCALE-4 criticality safety software. This includes both KENO V.a (Petrie and Landers 1995) and XSDRNPM. The CSAS criticality sequences 
and the SCALE 27-group library were used to calculate $\mathrm{k}_{\mathrm{eff}}$ over broad ranges of ${ }^{233} \mathrm{U}$, ${ }^{235} \mathrm{U}$, and ${ }^{239} \mathrm{Pu}$ critical systems. Of these experiments, about 70 were also calculated using XSDRNPM.

These critical experiment validation models were classified as follows:

1. Experiments from Jordan et al. (1986) that cover a broad range of geometry, fissile fuel mixture, moderator, and reflector combinations.

a. Low-enriched ${ }^{235} \mathrm{U}$ systems.

b. Primarily homogeneous water-moderated single units and arrays of large units. These include arrays of large low-enriched uranium metal billets moderated and reflected by water.

c. Models for highly enriched ${ }^{235} \mathrm{U}$ systems.

d. ${ }^{233} \mathrm{U}$ systems.

2. Experiments from Primm (1993) that include a harder spectra over a broad range of fissile materials and materials of construction.

a. ${ }^{233} \mathrm{U}$ metal systems, water-moderated systems at various concentrations, and arrays of large units.

b. Highly enriched ${ }^{235} \mathrm{U}$ systems. Highly thermal systems are excluded in order to validate harder thermal, epithermal, and fast systems.

c. ${ }^{239} \mathrm{Pu}$ systems. These include systems with variable ${ }^{240} \mathrm{Pu}$ content as well as systems with a range of fissile material form geometry and moderation level. Several arrays of large units are included.

3. Benchmark experiments from DeHart and Bowman (1994):

a. Fast and thermal systems. These include ${ }^{233} \mathrm{U},{ }^{235} \mathrm{U}$, and ${ }^{239} \mathrm{Pu}$ unreflected and waterand metal-reflected systems, graphite-moderated systems, and $\mathrm{UH}_{3}$ systems.

b. Thermal systems. These include highly enriched ${ }^{235} \mathrm{U}$ water-moderated systems, lowenriched ${ }^{235} \mathrm{U}$ lattices, and water-moderated ${ }^{239} \mathrm{Pu}$ systems.

c. Low-enriched light-water-reactor (LWR) reactor lattices. Both $\mathrm{UO}_{2}$ and mixed-oxide $\mathrm{UO}_{2}-\mathrm{PuO}_{2}$ lattices are included.

d. Fast-reactor mixed-oxide lattices and homogeneous ${ }^{235} \mathrm{U}$ systems.

The large number and variety of critical experiments included by Emmett and Jordan (1996) make the results of their validation general. For specific applications their bias and calculational acceptance $\mathrm{k}_{\mathrm{eff}} \mathrm{s}$ may be overly restrictive. When validating these codes for a specific application, an appropriate subset of the validation cases may be used to establish a problem specific bias and acceptance criterion. 
A paper in the transactions of the American Nuclear Society (Bowman et al. 1998) describes the verification and the validation process used for the SCALE code package. Bowman et al. provides a summary comparison of calculations of the 600 critical experiment models described in NUREG/CR-6483. Comparison is made of SCALE 4.2 using the 27-group ENDF/B-IV cross-section library with SCALE 4.3 using the 44-group ENDF/B-V library.

\subsubsection{Results Reported in NUREG/CR-6361}

Criticality Benchmark Guide for Light-Water-Reactor Fuel in Transportation and Storage Packages (NUREG/CR-6361) by Lichtenwalter et al. (1997) reports validation calculations for SCALE 4.3 using the 44-group ENDF/B-V cross-section library. In all, 180 benchmark experiment cases were compiled from 24 reports. Models of these experiments were input into KENO V.a to calculate values of $\mathrm{k}_{\mathrm{eff}}$.

Biases are discussed as a function of problem type. Calculations were repeated using the 238-group ENDF/B-V library to determine the adequacy of the 44-group structure. On average, the 238-group cross-sections returned results that were 0.35 percent lower than for the 44-group cross-sections. These benchmark calculations demonstrate that criticality safety calculations can be made using the 44-group ENDF/B-V cross-section library for a wide range of applications.

\subsection{RESULTS FROM AST BRAVO 5200M PC CALCULATIONS}

Calculational results for 46 benchmark experiments are described in Tables 5-1 through 5-4. The SCALE-4.3 calculations were performed on a $200 \mathrm{MHz}$ AST Bravo MS 5200 personal computer using both the 27- and 44-group cross-sections. The 46 experiments are a subset of the benchmarks listed in NUREG/CR-6483 (Emmett and Jordan 1996) (see Appendix B).

Experiments are grouped according to type. ${ }^{233} \mathrm{U}$ benchmark experiments are listed in Table 5-1; plutonium benchmarks in Table 5-2; uranium benchmarks in Table 5-3, and iron benchmarks in Table 5-4. These groupings are then further broken down into configurations where fissioning results primarily from slow neutrons (i.e., moderated systems) and configurations where fissioning results primarily from fast neutron (i.e., unmoderated systems). The tables list the calculated $\mathrm{k}_{\infty}$ for each experiment, along with the $\mathrm{AEG}, \mathrm{AEF}, \mathrm{H} / \mathrm{X}$ ratio, and isotopic weight percent $(w t \%)$ of interest.

\subsubsection{Experiments with ${ }^{233} \mathrm{U}$}

Table 5-1 lists XSDRNPM results for calculations of ${ }^{233} U$ systems. There are two thermal experiments (uranyl nitrate-water solutions) and eleven fast systems (metal spheres). While the uranium in the $\mathrm{K}$ Basin sludge does not contain a significant fraction of ${ }^{233} \mathrm{U}$, the calculations do support the ability of XSDRNPM to calculate critical systems. The results are divided into thermal and fast results. The AEF for the moderated systems fall in the narrow range from 0.0459 to $0.0578 \mathrm{eV}$, corresponding to an $\mathrm{H} / \mathrm{X}$ atom ratio from 405 to 658 . The AEF for the fast (unmoderated) systems fall in the range from 0.728 to $1.08 \mathrm{MeV}$, corresponding to an $\mathrm{H} / \mathrm{X}$ atom ratio of 0 . Agreement of the calculated $\mathrm{k}_{\infty}$ with the benchmark experiments is good for both sets 
of cross sections in both energy ranges. However, the 44-group ENDF/B-V cross sections provided consistently better results than the 27-group ENDF/B-IV cross sections.

\subsubsection{Experiments with Plutonium}

Table 5-2 lists XSDRNPM results for the plutonium benchmark experiments. There are ten thermal experiments (plutonium-water solutions) and four fast systems (metal spheres). Most of the calculations are for plutonium with a ${ }^{240} \mathrm{Pu}$ content close to $5 \mathrm{wt} \%$. One experiment is for high burnup plutonium in which the ${ }^{240} \mathrm{Pu}$ content is $45 \mathrm{wt} \%$. In all cases the calculated $\mathrm{k}_{\text {eff }}$ values agree well with experimental data. The plutonium in $\mathrm{K}$ Basin sludge has a ${ }^{240} \mathrm{Pu}$ content up to $16 \mathrm{wt} \%$. The results are divided into thermal and fast systems. The AEF for the moderated systems fall in the range from 0.0371 to $0.311 \mathrm{eV}$, corresponding to an $\mathrm{H} / \mathrm{X}$ atom ratio from 125 to 3,694 . For thermal systems the average calculated $k_{\infty}$ is $1.0129 \pm 0.0068$ for 27 -group cross sections and $1.0077 \pm 0.0065$ for 44 -group cross sections. The AEF for the fast (metal) systems fall in the range from 0.079 to $1.16 \mathrm{MeV}$ (i.e., an $\mathrm{H} / \mathrm{X}$ of 0 ). For fast systems the average calculated $k_{\infty}$ is $1.0108 \pm 0.0094$ for 27 -group cross sections and $1.0112 \pm 0.0167$ for 44 -group cross sections.

\subsubsection{Experiments with ${ }^{235} \mathrm{U}$}

Table 5-3 lists XSDRNPM results for the ${ }^{235} \mathrm{U}$ benchmark experiments. There are ten thermal systems (uranium rod lattices in water and highly enriched uranium nitride in water) and nine fast systems (metal spheres). The five rod lattice experiments are for $1.3 \mathrm{wt} \%{ }^{235} \mathrm{U}$ enriched uranium rod lattices in water. The rod diameters are either $0.9728 \mathrm{~cm}$ or $0.9830 \mathrm{~cm}$ diameter and lattice pitch is varied between $1.5578 \mathrm{~cm}$ and $2.1740 \mathrm{~cm}$. There are five experiments of highly enriched uranium nitride in water over the range of $\mathrm{H} / \mathrm{X}$ ratio from 972 to 1835 . The ${ }^{235} \mathrm{U}$ enrichment ranges from 91.2 to $95.3 \mathrm{wt} \%$. The nine fast calculations are for unmoderated uranium metal spheres with various reflectors. The AEF for moderated systems fall between 0.0292 and $0.344 \mathrm{eV}$, and the $\mathrm{H} / \mathrm{X}$ atom ratio fall between 214 and 1835 . For thermal (moderated) lattices with an AEF between 0.113 and $0.344 \mathrm{eV}$ the average calculated $\mathrm{k}_{\infty}$ is $1.0139 \pm 0.0034$ for 27 -group cross sections and $1.0231 \pm 0.0037$ for 44 -group cross sections. For homogeneous solutions with an AEF between 0.0292 and $0.0339 \mathrm{eV}$ the average calculated $\mathrm{k}_{\infty}$ is $0.9967 \pm 0.0014$ for 27 -group cross sections and $0.9972 \pm 0.0013$ for 44 -group cross sections. The AEF for the fast (metal) systems fall between 2.77 and $878 \mathrm{keV}$ with an $\mathrm{H} / \mathrm{X}$ atom ratio between 0 . and 3.2. For fast systems the average calculated $\mathrm{k}_{\infty}$ is $1.01595 \pm 0.0180$ for 27 group cross sections and $1.0109 \pm 0.0091$ for 44 -group cross sections. When all ${ }^{235} \mathrm{U}$ experiments are combined, the average $\mathrm{k}_{\infty}$ is found to be $1.0103 \pm 0.0148$ for the 27-group and $1.0105 \pm 0.0115$ for the 44 -group cross sections. These values are almost identical. 
HNF-3950 Rev. 0

\subsubsection{Experiments With Iron}

A primary component in $\mathrm{K}$ Basin sludge when received at tank farms will be iron. The mass ratio of iron to plutonium in the actual waste is expected to exceed 200. Table 5-4 lists

XSDRNPM results for systems that contain iron. There are two thermal experiments and four fast experiments listed. However, the mass ratio of iron to heavy metal in the thermal systems is no greater than 0.005 , a value far less than in $\mathrm{K}$ Basin sludge. Although the iron to heavy metal mass ratio is higher for the fast systems, they are still less than the mass ratio in $\mathrm{K}$ Basin sludge. In addition, these systems do not represent the high water content found in $\mathrm{K}$ Basin sludge (i.e., the highly moderated state).

Heterogeneous experimental benchmarks are available in which iron is a component of steel in rod cladding, reflector walls, or separator plates. Both NUREG/CR-6483 (Emmett and Jordan 1996) and NUREG/CR-6361 (Lichtenwalter et al. 1997) contain numerous cases in which iron is used in this manner, but these cases are complex and are not adequately modeled by XSDRNPM. Nevertheless, the agreement between KENO V.a results and experiments is found to be good for these experiments. Table 5-5 lists results from a subset of these calculations using KENO V.a with the 27- and 44-group libraries, calculated on the AST Bravo PC.

This supports the conclusion that cross section sets validated for KENO V.a will provide accurate results when run using XSDRNPM. Even in these configurations, however, the iron content is still considerably less than in $\mathrm{K}$ Basin sludge.

For one and two dimensional systems, Emmett and Jordan (1996) found XSDRNPM and KENO V.a agree to within $1.0 \% \Delta \mathrm{k}$, and in most cases agreement was closer than $0.3 \% \Delta \mathrm{k}$. Systems modeled in one or two dimensions are calculated as accurately with XSDRNPM as with KENO V.a. Bias for one or two dimension systems are expected to be nearly identical for XSDRNPM as for KENO V.a. 
HNF-3950 Rev. 0

Table 5-1. XSDRNPM Calculations for ${ }^{233} \mathrm{U}$ Benchmark Experiments ${ }^{1}$

\begin{tabular}{|c|c|c|c|c|c|c|c|}
\hline \multicolumn{8}{|c|}{ Moderated Configurations - Solutions } \\
\hline Case & $\begin{array}{c}\mathrm{k}_{\infty} \\
\text { 27-Group }\end{array}$ & $\begin{array}{c}\mathrm{k}_{\infty} \\
\text { 44-Group }\end{array}$ & $\mathrm{AEG}^{2}$ & $\begin{array}{l}\mathrm{AEF}^{2} \\
(\mathrm{eV})\end{array}$ & $\mathrm{H} / \mathrm{X}$ Ratio & ${ }^{233} \mathrm{U}$ & Description \\
\hline $111 \_20$ & 1.01400 & 0.99854 & 36.8 & $5.78 \mathrm{E}-02$ & 405 & 98.7 & Uranyl nitrate-water solution \\
\hline $111 \_25$ & 1.02686 & 1.01431 & 37.4 & $4.59 \mathrm{E}-02$ & 658 & 98.7 & Uranyl nitrate-water solution \\
\hline $\begin{array}{l}\text { Average } \\
\pm \text { Std. Dev. }\end{array}$ & $\begin{array}{r}1.02043 \\
\pm .00909 \\
\end{array}$ & $\begin{array}{r}1.00643 \\
\pm .01115 \\
\end{array}$ & & & & & \\
\hline \multicolumn{8}{|c|}{ Fast Configurations } \\
\hline 172701 & 0.96713 & 0.99768 & 7.9 & $1.08 \mathrm{E}+06$ & 0 & 98.1 & Bare metal sphere, no reflector \\
\hline $1727 \_02$ & 0.98107 & 0.99746 & 8.6 & $7.90 \mathrm{E}+05$ & 0 & 98.1 & Reflected metal spheres, uranium reflector \\
\hline 172703 & 0.97928 & 0.99664 & 8.3 & $9.01 \mathrm{E}+05$ & 0 & 98.2 & Reflected metal spheres, uranium reflector \\
\hline $1727 \_04$ & 0.97600 & 0.99790 & 8.2 & $9.78 \mathrm{E}+05$ & 0 & 98.2 & Reflected metal spheres, uranium reflector \\
\hline $1727 \_05$ & 0.97669 & 1.00894 & 8.5 & $8.34 \mathrm{E}+05$ & 0 & 98.2 & Reflected metal spheres, tungsten alloy reflector \\
\hline $1727 \_06$ & 0.97634 & 1.00751 & 8.3 & $9.32 \mathrm{E}+05$ & 0 & 98.2 & Reflected metal spheres, tungsten alloy reflector \\
\hline $1727 \_07$ & 0.99619 & 1.00767 & 8.6 & $7.28 \mathrm{E}+05$ & 0 & 98.2 & Reflected metal spheres, natural uranium reflector \\
\hline $1727 \_08$ & 0.98395 & 1.00344 & 8.3 & $9.03 \mathrm{E}+05$ & 0 & 98.2 & Reflected metal spheres, tungsten alloy reflector \\
\hline $1727 \_14$ & 0.97626 & 1.00118 & 8.0 & $1.04 \mathrm{E}+06$ & 0 & 98.1 & Reflected metal spheres, enriched uranium reflector \\
\hline $1727 \_15$ & 0.98256 & 1.00360 & 8.1 & $1.03 \mathrm{E}+06$ & 0 & 98.1 & Reflected metal spheres, enriched uranium reflector \\
\hline JEZB23 & 0.96475 & 0.99525 & 8.0 & $1.06 \mathrm{E}+06$ & 0 & 98.1 & Bare metal sphere, no reflector \\
\hline $\begin{array}{l}\text { Average } \\
\pm \text { Std. Dev. } \\
\end{array}$ & $\begin{array}{r}0.97820 \\
\pm .00838 \\
\end{array}$ & $\begin{array}{r}1.00157 \\
\pm .00494 \\
\end{array}$ & & & & & \\
\hline \multicolumn{8}{|c|}{ Combined Average (Moderated and Fast Configurations) } \\
\hline $\begin{array}{l}\text { Overall Average } \\
\pm \text { Std. Dev. }\end{array}$ & $\begin{array}{r}0.98470 \\
\pm .001780 \\
\end{array}$ & $\begin{array}{r}1.00232 \\
\pm .00583 \\
\end{array}$ & & & & & \\
\hline
\end{tabular}

Notes: $\quad{ }^{1}$ All experiments from NUREG/CR-6483 (Emmett and Jordan 1996) ${ }^{2}$ Uses 44-group cross-sections. 
HNF-3950 Rev. 0

Table 5-2. XSDRNPM Calculations for Plutonium Benchmark Experiments ${ }^{1}$

\begin{tabular}{|c|c|c|c|c|c|c|c|}
\hline Case & $\begin{array}{l}k_{\infty} \\
27-G r o u p\end{array}$ & $\begin{array}{l}k_{\infty} \\
\text { 44-Group }\end{array}$ & $\mathrm{AEG}^{2}$ & $\begin{array}{l}\mathrm{AEF}^{2} \\
(\mathrm{eV})\end{array}$ & $\begin{array}{l}\text { H/X } \\
\text { Ratio }\end{array}$ & $\begin{array}{l}{ }^{240} \mathrm{Pu} \\
\text { wt } \%\end{array}$ & Description \\
\hline \multicolumn{8}{|c|}{ Moderated Configurations - Solutions } \\
\hline 211001 & 1.00487 & 1.00139 & 38.1 & $3.71 \mathrm{E}-02$ & 3694 & 0.0 & $\mathrm{Pu}$-water solution \\
\hline$\overline{\mathrm{PNL} 3}$ & 1.00059 & 0.99577 & 37.1 & $4.93 \mathrm{E}-02$ & 1154 & 4.2 & Pu-water solution, bare sphere \\
\hline $2110 \_30$ & 1.01845 & 1.01424 & 37.2 & $4.91 \mathrm{E}-02$ & 1067 & 4.6 & $\mathrm{Pu}$-water solution, $\mathrm{Pu}\left(\mathrm{NO}_{3}\right)_{4}$ \\
\hline $2110 \_32$ & 1.01653 & 1.01245 & 37.1 & $5.05 \mathrm{E}-02$ & 1031 & 4.6 & $\mathrm{Pu}$-water solution, $\mathrm{Pu}\left(\mathrm{NO}_{3}\right)_{4}$ \\
\hline $2110 \_03$ & 1.01722 & 1.01199 & 37.0 & $5.18 \mathrm{E}-02$ & 980 & 0.5 & $\mathrm{Pu}$-water solution, $\mathrm{Pu}\left(\mathrm{NO}_{3}\right)_{4}$ \\
\hline 2110 & 1.01751 & 1.01280 & 36.5 & $6.06 \mathrm{E}-02$ & 758 & 4.6 & $\mathrm{Pu}$-water solution, $\mathrm{Pu}\left(\mathrm{NO}_{3}\right)_{4}$ \\
\hline $2110 \quad 07$ & 1.01712 & 1.01282 & 35.4 & $8.69 \mathrm{E}-02$ & 422 & 4.7 & $\mathrm{Pu}$-water solution, $\mathrm{Pu}\left(\mathrm{NO}_{3}\right)_{4}$ \\
\hline $2110 \_02$ & 1.01567 & 1.00745 & 31.6 & $3.11 \mathrm{E}-01$ & 125 & 4.6 & $\mathrm{Pu}$-water solution, $\mathrm{Pu}\left(\mathrm{NO}_{3}\right)_{4}$ \\
\hline PNLĒB & 1.01657 & 1.00840 & 31.7 & $3.00 \mathrm{E}-01$ & 125 & 4.6 & Pu-water solution, bare sphere \\
\hline HI240R & 1.00435 & 0.99990 & 36.9 & $5.43 E-02$ & 623 & 42.9 & Pu nitrate-water, high ${ }^{240} \mathrm{Pu}$ wt. $\%$, water reflected \\
\hline $\begin{array}{l}\text { Average } \\
\pm \text { Std. Dev. } \\
\end{array}$ & $\begin{array}{r}1.01289 \\
\pm 0.00677 \\
\end{array}$ & $\begin{array}{r}1.00772 \\
\pm 0.00649 \\
\end{array}$ & & & & & \\
\hline \multicolumn{8}{|c|}{ Fast Configurations } \\
\hline 172709 & 1.00800 & 1.00436 & 12.0 & $7.90 \mathrm{E}+04$ & 0 & 5.2 & Pu metal sphere, water reflector \\
\hline $1727-10$ & 1.00113 & 1.00027 & 7.8 & $1.16 \mathrm{E}+06$ & 0 & 4.9 & Pu metal sphere, enriched uranium reflector \\
\hline $2109 \_25$ & 1.01053 & 1.00414 & 8.4 & $8.75 \mathrm{E}+05$ & 0 & 4.8 & Pu metal sphere, natural uranium reflector \\
\hline$\overline{\text { ZPR67 }}$ & 1.02348 & 1.03614 & 10.9 & $9.89 \mathrm{E}+04$ & 0 & 11.8 & $\mathrm{Pu}$ in depleted uranium, $\mathrm{Pu} / \mathrm{U}=0.174$, $\mathrm{DU}$ reflector \\
\hline $\begin{array}{l}\text { Average } \\
\pm \text { Std. Dev. } \\
\end{array}$ & $\begin{array}{r}1.01079 \\
\pm 0.00935 \\
\end{array}$ & $\begin{array}{r}1.01123 \\
\pm 0.01671 \\
\end{array}$ & & & & & \\
\hline \multicolumn{8}{|c|}{ Combined Average (Moderated and Fast Plutonium Configurations) } \\
\hline $\begin{array}{l}\text { Overall } \\
\text { Average } \\
\pm \text { Std. Dev. }\end{array}$ & $\begin{array}{r}1.01229 \\
\pm .00727 \\
\end{array}$ & $\begin{array}{r}1.00872 \\
+.00982 \\
\end{array}$ & & & & & \\
\hline
\end{tabular}

Notes: $\quad{ }^{1}$ All experiments from NUREG/CR-6483 (Emmett and Jordan 1996) $\quad{ }^{2}$ Uses 44-group cross-sections. 
Table 5-3. XSDRNPM Calculations for Uranium Benchmark Experiments ${ }^{1}$ ( 2 sheets)

\begin{tabular}{|c|c|c|c|c|c|c|c|}
\hline Case & $\begin{array}{l}k_{\infty} \\
\text { 27-Group }\end{array}$ & $\begin{array}{l}k_{\infty} \\
\text { 44-Group }\end{array}$ & AEG $^{2}$ & $\begin{array}{l}\mathrm{AEF} \\
(\mathrm{eV})\end{array}$ & $\begin{array}{l}\mathbf{H} / \mathbf{X} \\
\text { Ratio }\end{array}$ & $\begin{array}{r}235 \mathrm{U} \\
w t \%\end{array}$ & Description \\
\hline \multicolumn{8}{|c|}{ Moderated Configurations - $\mathrm{UO}_{2}$ Triangular Lattices In Water } \\
\hline BAPL1 & 1.00928 & 1.01836 & 34.6 & $2.09 \mathrm{E}-01$ & 250 & 1.31 & Fuel OD $=0.9728 \mathrm{~cm}$, pitch $=1.5578 \mathrm{~cm}$ \\
\hline BAPL2 & 1.01302 & 1.02140 & 35.3 & $1.56 \mathrm{E}-01$ & 319 & 1.31 & Fuel OD $=0.9728 \mathrm{~cm}$, pitch $=1.6523 \mathrm{~cm}$ \\
\hline BAPL3 & 1.01498 & 1.02252 & 36.0 & $1.13 \mathrm{E}-01$ & 438 & 1.31 & Fuel OD $=0.9728 \mathrm{~cm}$, pitch $=1.8057 \mathrm{~cm}$ \\
\hline TRX1 & 1.01341 & 1.02478 & 33.6 & $3.44 \mathrm{E}-01$ & 214 & 1.29 & Fuel OD $=0.9830 \mathrm{~cm}$, pitch $=1.8060 \mathrm{~cm}$ \\
\hline TRX2 & 1.01868 & 1.02830 & 35.2 & $1.67 \mathrm{E}-01$ & 376 & 1.29 & Fuel OD $=0.9830 \mathrm{~cm}$, pitch $=2.1740 \mathrm{~cm}$ \\
\hline $\begin{array}{l}\text { Average } \\
\pm \text { Std. Dev. }\end{array}$ & $\begin{array}{r}1.01387 \\
+0.00340 \\
\end{array}$ & $\begin{array}{r}1.02307 \\
\pm 0.00373 \\
\end{array}$ & & & & & \\
\hline \multicolumn{8}{|c|}{ Moderated Configurations - Solutions } \\
\hline ORNL10 & 0.99592 & 0.99766 & 38.8 & $2.92 \mathrm{E}-02$ & 1835 & 91.2 & Uranium nitride - water solution \\
\hline ORNL1 & 0.99832 & 0.99832 & 38.7 & $3.05 \mathrm{E}-02$ & 1378 & 93.2 & Uranium nitride - water solution \\
\hline ORNL2 & 0.99788 & 0.99815 & 38.6 & $3.19 \mathrm{E}-02$ & 1177 & 95.3 & Uranium nitride - water solution, $10 \mathrm{~B}$ \\
\hline ORNL3 & 0.99492 & 0.99519 & 38.5 & $3.32 \mathrm{E}-02$ & 1033 & 93.8 & Uranium nitride - water solution, $10 \mathrm{~B}$ \\
\hline ORNL4 & 0.99644 & 0.99666 & 38.4 & $3.39 \mathrm{E}-02$ & 972 & 93.5 & Uranium nitride - water solution, $10 \mathrm{~B}$ \\
\hline $\begin{array}{l}\text { Average } \\
\pm \text { Std. Dev. } \\
\end{array}$ & $\begin{array}{c}0.99670 \\
\pm 0.00140 \\
\end{array}$ & $\begin{array}{c}0.99720 \\
+0.00129 \\
\end{array}$ & \\
\hline \multicolumn{8}{|c|}{ Fast Configurations } \\
\hline BIG10 & 1.00153 & 1.01868 & 9.2 & $4.69 \overline{\mathrm{E}}+05$ & 0 & 10.1 & U metal sphere, depleted uranium reflector \\
\hline FLAT25 & 1.00885 & 0.99811 & 8.6 & $7.75 \mathrm{E}+05$ & 0 & 93.2 & U metal sphere, natural uranium reflector \\
\hline GODIVA & 1.00622 & 1.00139 & 8.4 & $8.78 \mathrm{E}+05$ & 0 & 93.7 & U metal sphere, bare \\
\hline $\mathrm{H} 2 \mathrm{OX} 1$ & 1.00875 & 1.00432 & 13.7 & $2.82 \mathrm{E}+04$ & 0 & 93.9 & U metal sphere, water reflector \\
\hline UH3NI & 1.06137 & 1.01040 & 14.5 & $2.87 \mathrm{E}+03$ & 3.2 & 93.1 & $\overline{\mathrm{U}}$ metal sphere, $\mathrm{C}^{235} \mathrm{U}=1.2$, nickel reflector \\
\hline UH3UR & 1.02183 & 1.00676 & 14.5 & $2.77 \mathrm{E}+03$ & 3.2 & 93.1 & $\begin{array}{l}\text { U metal sphere, } \overline{\mathrm{C}} /^{235} \mathrm{U}=1.2 \text {, natural uranium } \\
\text { reflector }\end{array}$ \\
\hline ZPR311 & 1.00688 & 1.02001 & 9.3 & $4.47 \mathrm{E}+05$ & 0 & 11.6 & U metal sphere, depleted uranium reflector \\
\hline
\end{tabular}

Notes: 'All experiments from NUREG/CR-6483 (Emmett and Jordan 1996)

${ }^{2}$ Uses 44-group cross-sections. 
HNF-3950 Rev. 0

Table 5-3. XSDRNPM Calculations for Uranium Benchmark Experiments. ${ }^{1}$ (2 sheets)

\begin{tabular}{|c|c|c|c|c|c|c|c|}
\hline Case & $\begin{array}{c}\mathrm{k}_{\infty} \\
\text { 27-Group }\end{array}$ & $\begin{array}{c}\mathrm{k}_{\infty} \\
\text { 44-Group }\end{array}$ & $\mathrm{AEG}^{2}$ & $\begin{array}{l}\mathrm{AEF}^{2} \\
(\mathrm{eV})\end{array}$ & $\mathrm{H} / \mathrm{X}$ Ratio & $\begin{array}{l}{ }^{235} \mathrm{U} \\
\mathrm{wt} \%\end{array}$ & Description \\
\hline \multicolumn{8}{|c|}{ Fast Configurations (Cont'd) } \\
\hline ZPR312 & 1.01261 & 1.01376 & 9.9 & $2.69 \mathrm{E}+05$ & 0 & 20.8 & U metal sphere, depleted uranium reflector \\
\hline ZPR66A & 1.01554 & 1.02469 & 11.5 & $6.02 \mathrm{E}+04$ & 0 & 16.4 & U metal sphere, depleted uranium reflector \\
\hline $\begin{array}{l}\text { Average } \\
\pm \text { Std. Dev. }\end{array}$ & $\begin{array}{r}1.01595 \\
\pm 0.01801\end{array}$ & $\begin{array}{c}1.01090 \\
\pm 0.00906\end{array}$ & & & & & \\
\hline \multicolumn{8}{|c|}{ Combined Average (Moderated and Fast Uranium Configurations) } \\
\hline $\begin{array}{l}\text { Overall } \\
\text { Average } \\
\pm \text { Std. Dev. }\end{array}$ & $\begin{array}{r}1.01034 \\
\pm .01477 \\
\end{array}$ & $\begin{array}{r}1.01050 \\
\pm .01154\end{array}$ & & & & & \\
\hline
\end{tabular}

Notes: $\quad$ 'All Experiments from NUREG/CR-6483 (Emmett and Jordan 1996)

${ }^{2}$ Uses 44-group cross-sections. 
HNF-3950 Rev. 0

Table 5-4. XSDRNPM Calculations for Iron Benchmark Experiments ${ }^{1}$

\begin{tabular}{|c|c|c|c|c|c|c|}
\hline Case & $\begin{array}{c}\mathrm{k}_{\infty} \\
27-\text {-Group }\end{array}$ & $\begin{array}{c}\mathrm{k}_{\infty} \\
\text { 44-Group }\end{array}$ & $\mathrm{AEG}^{2}$ & $\begin{array}{l}\mathrm{AEF}^{2} \\
(\mathrm{eV})\end{array}$ & $\begin{array}{c}\mathrm{Fe} / \mathrm{HM} \\
\text { Ratio }\end{array}$ & Description \\
\hline \multicolumn{7}{|c|}{ Moderated Configurations - Solutions } \\
\hline PNL3 & 1.00059 & 0.99577 & 37.1 & $4.93 \mathrm{E}-02$ & 0.005 & Pu-water solution, bare sphere \\
\hline PNL6B & 1.01657 & 1.00840 & 31.7 & $3.00 \mathrm{E}-01$ & 0.002 & Pu-water solution, bare sphere \\
\hline $\begin{array}{l}\text { Average } \\
\pm \text { Std. Dev. }\end{array}$ & $\begin{array}{r}1.00858 \\
\pm .01130 \\
\end{array}$ & $\begin{array}{r}1.00209 \\
\pm .00893 \\
\end{array}$ & & & & \\
\hline \multicolumn{7}{|c|}{ Fast Configurations } \\
\hline ZPR311 & 1.00688 & 1.02001 & 9.3 & $4.47 \mathrm{E}+05$ & 0.034 & U metal sphere, depleted uranium reflector \\
\hline ZPR312 & 1.01261 & 1.01376 & 9.9 & $2.69 \mathrm{E}+05$ & 0.062 & U metal sphere, depleted uranium reflector \\
\hline ZPR66A & 1.01554 & 1.02469 & 11.5 & $6.02 \mathrm{E}+04$ & 0.453 & U metal sphere, depleted uranium reflector \\
\hline ZPR67 & 1.02348 & 1.03614 & 10.9 & $9.89 \mathrm{E}+04$ & 0.446 & $\mathrm{Pu}$ in depleted uranium, $\mathrm{Pu} / \mathrm{U}=0.174, \mathrm{DU}$ reflector \\
\hline $\begin{array}{l}\text { Average } \\
\pm \text { Std. Dev. }\end{array}$ & $\begin{array}{r}1.01463 \\
\pm .00691\end{array}$ & $\begin{array}{r}1.02365 \\
\pm .00945\end{array}$ & & & & \\
\hline \multicolumn{7}{|c|}{ Combined Average (Moderated and Fast Iron Configurations) } \\
\hline $\begin{array}{l}\text { Overall } \\
\text { Average } \\
\pm \text { Std. Dev. }\end{array}$ & $\begin{array}{r}1.01646 \\
\pm .01391 \\
\end{array}$ & $\begin{array}{r}1.01261 \\
\pm .00800 \\
\end{array}$ & & & & \\
\hline
\end{tabular}

Notes: ${ }^{1}$ All experiments from NUREG/CR-6483 (Emmett and Jordan 1996). $\quad{ }^{2}$ Uses 44-group cross-sections. 
HNF-3950 Rev. 0

Table 5-5. KENO V.a Calculations for Steel Plate Experiments ${ }^{1}$

\begin{tabular}{|c|c|c|c|c|c|c|c|}
\hline File & $\begin{array}{c}\mathrm{k}_{\infty} \\
27-G r o u p\end{array}$ & $\underset{\text { 44-Group }}{\mathrm{k}_{\infty}}$ & $\mathrm{AEF}^{2}(\mathrm{eV})$ & $\begin{array}{l}{ }^{235} \mathrm{U} \\
w t \%\end{array}$ & $\begin{array}{c}\mathrm{Fe} / \mathrm{U} \\
\text { Mass Ratio }\end{array}$ & $\begin{array}{l}\text { Plate Thick } \\
\quad(\mathrm{cm})\end{array}$ & Description \\
\hline P2438SLG & $0.9948 \pm 0.0014$ & $0.9981 \pm 0.0014$ & 0.073 & 2.35 & 0.000 & None & Simple square lattice \\
\hline P2438SS & $0.9938 \pm 0.0013$ & $0.9961 \pm 0.0014$ & 0.074 & 2.35 & 0.024 & 0.485 & Stainless steel separator plates \\
\hline P2615SS & $0.9967 \pm 0.0016$ & $0.9980 \pm 0.0016$ & $0.0 \overline{93}$ & 4.31 & 0.046 & 0.485 & Stainless steel separator plates \\
\hline P3314SLG & $0.9924 \pm 0.0016$ & $0.9974 \pm 0.0016$ & 0.198 & 4.31 & 0.000 & None & Simple square lattice \\
\hline P3314SS1 & $0.9986 \pm 0.0016$ & $1.0025 \pm 0.0016$ & 0.211 & 4.31 & 0.080 & 0.302 & Steel separator plates \\
\hline P3314SS2 & $0.9916 \pm 0.0015$ & $1.0043 \pm 0.0015$ & 0.204 & 4.31 & 0.045 & 0.302 & Steel separator plates \\
\hline P3314SS3 & $0.9962 \pm 0.0015$ & $0.9988 \pm 0.0015$ & 0.213 & 4.31 & 0.103 & 0.485 & Steel separator plates \\
\hline P3314SS4 & $0.9903 \pm 0.0014$ & $1.0010 \pm 0.0015$ & $0.1 \overline{32}$ & 4.31 & 0.075 & 0.485 & Steel separator plates \\
\hline P3314SS5 & $0.9978 \pm 0.0014$ & $0.9974 \pm 0.0013$ & $0.2 \overline{33}$ & 2.35 & 0.012 & 0.302 & Steel separator plates \\
\hline P3314SS6 & $0.9930 \pm 0.0015$ & $1.0015 \pm 0.0016$ & 0.194 & 4.31 & 0.018 & 0.302 & Steel separator plates \\
\hline Average & $0.9945 \pm 0.0015$ & $0.9995 \pm 0.0015$ & & & & & \\
\hline
\end{tabular}

Note: $\quad{ }^{1}$ All experiments from NUREG/CR-6361 (Lichtenwalter et al. 1997), $\quad{ }^{2}$ Uses 44-group cross-sections. 
HNF-3950 Rev. 0

This page intentionally left blank. 
HNF-3950 Rev. 0

\subsection{ADDITIONAL COMPARISONS}

Additional comparisons are made to demonstrate the ability of XSDRNPM to calculate criticality parameters. Comparisons are made to KENO V.a calculations, and calculations run in the standalone mode are compared to CSASIX sequence calculations. In addition, configurations selected from Paxton and Pruvost (1987) and from the Criticality Handbook to represent tank waste are calculated.

\subsection{XSDRNPM AND KENO V.a RESULTS}

Configurations of primary importance to the evaluation of $\mathrm{K}$ Basin sludge are recalculated using KENO V.a, a code using an entirely different method from that used by XSDRNPM. The same cross section sets were used for both calculations. Since these two methods are entirely different and independent, the ability to obtain close agreement for $\mathrm{k}_{\infty}$ demonstrates that the codes are performing the intended calculations.

XSDRNPM is used to compute $\mathrm{k}_{\infty}$ for postulated sludge compositions over the entire range of water concentrations. The water content at which the maximum $\mathrm{k}_{\infty}$ occurs is called the optimum (or optimal) water concentration. Maximum $\mathrm{k}_{\infty}$ always occurs for a well moderated configuration. Configurations for which the water content provides maximum $\mathrm{k}_{\infty}$ are shown in Table 6-1.

Maximum $\mathrm{k}_{\infty}$ for each assumed sludge composition was also calculated using KENO V.a, and the results are shown in Table 6-1 next to the corresponding XSDRNPM value.

Calculations in Table 6-1 are made using the SCALE 4.3 code system using 27-group cross sections. For each calculation the total weight of solids (everything not water) is held constant at $2,000 \mathrm{~g} / \mathrm{L}$. Iron is assumed to be present as $\mathrm{FeO}$, plutonium as $\mathrm{PuO}_{2}$, and uranium as $\mathrm{UO}_{2}$. Heavy metal (HM) refers to the sum of the plutonium and uranium metal. The AEF falls between 0.09 and $0.19 \mathrm{eV}$ for these configurations.

When the maximum $\mathrm{k}_{\infty}$ is near 1.0, XSDRNPM usually gives a value that is within 0.004 of the corresponding KENO V.a value. In all cases in Table 6-1, the agreement is to within 0.006 . When iron is added, the maximum $\mathrm{k}_{\infty}$ decreases. When maximum $\mathrm{k}_{\infty}$ is around 0.70 , XSDRNPM gives a maximum $k_{\infty}$ which is always larger than the corresponding KENO V.a . The greatest difference if found to be about 0.007 for the configurations examined.

In conclusion, agreement between XSDRNPM and KENO V.a maximum $\mathrm{k}_{\infty}$ is found to be within 0.007 for the range of sludge types being examined. For well subcritical configurations, as is always the case with tank waste, XSDRNPM tends to give a slightly larger maximum $\mathrm{k}_{\infty}$ and is therefore slightly more conservative. 


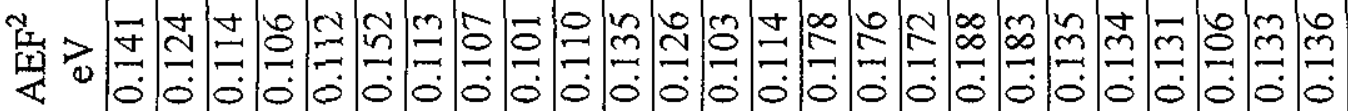

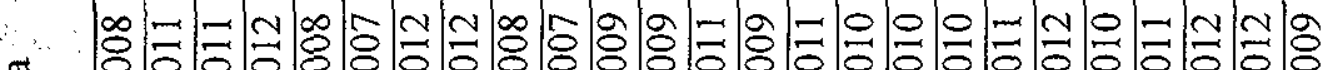

"

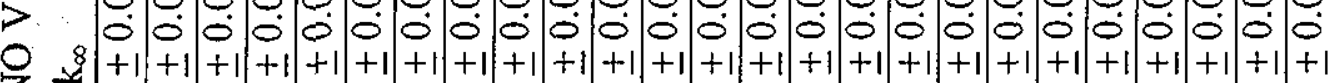

- $1+1+1+1+1+1+1+1+1+1+1+1+1+1+1+1+1+1+1+1+1+1+1+1+1$

స̦心

ర

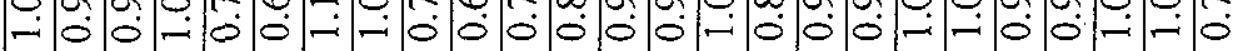

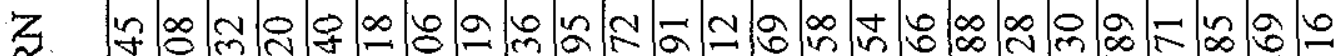

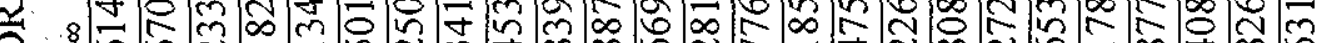

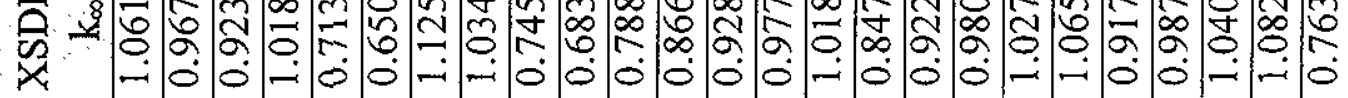

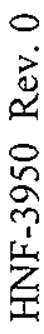

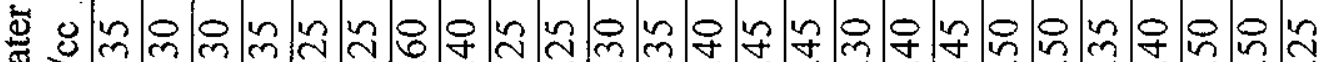

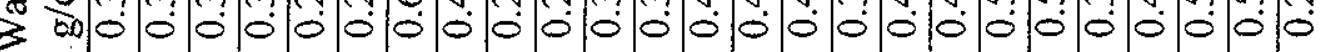

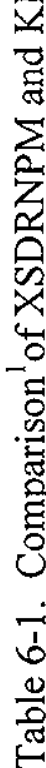

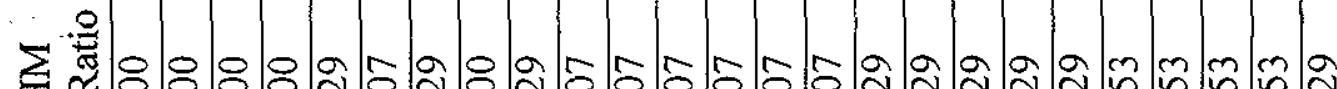

造

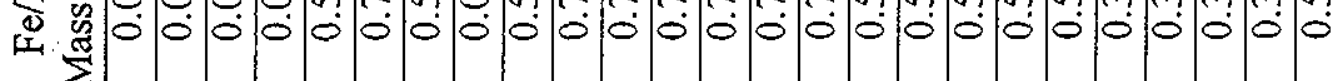

F 至

点

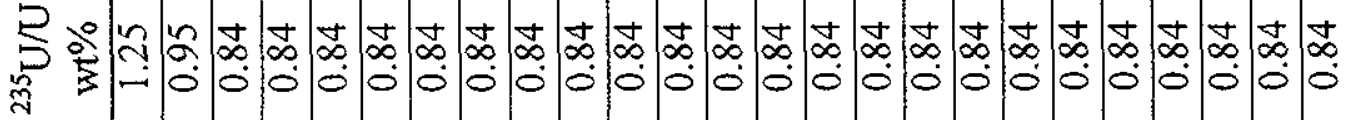

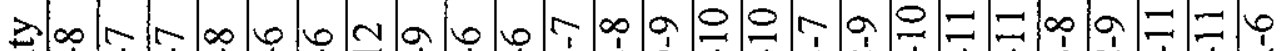

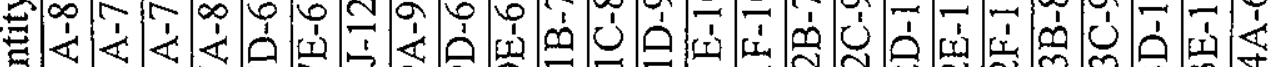

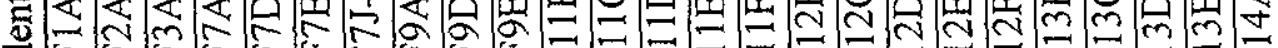

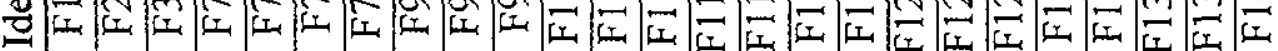




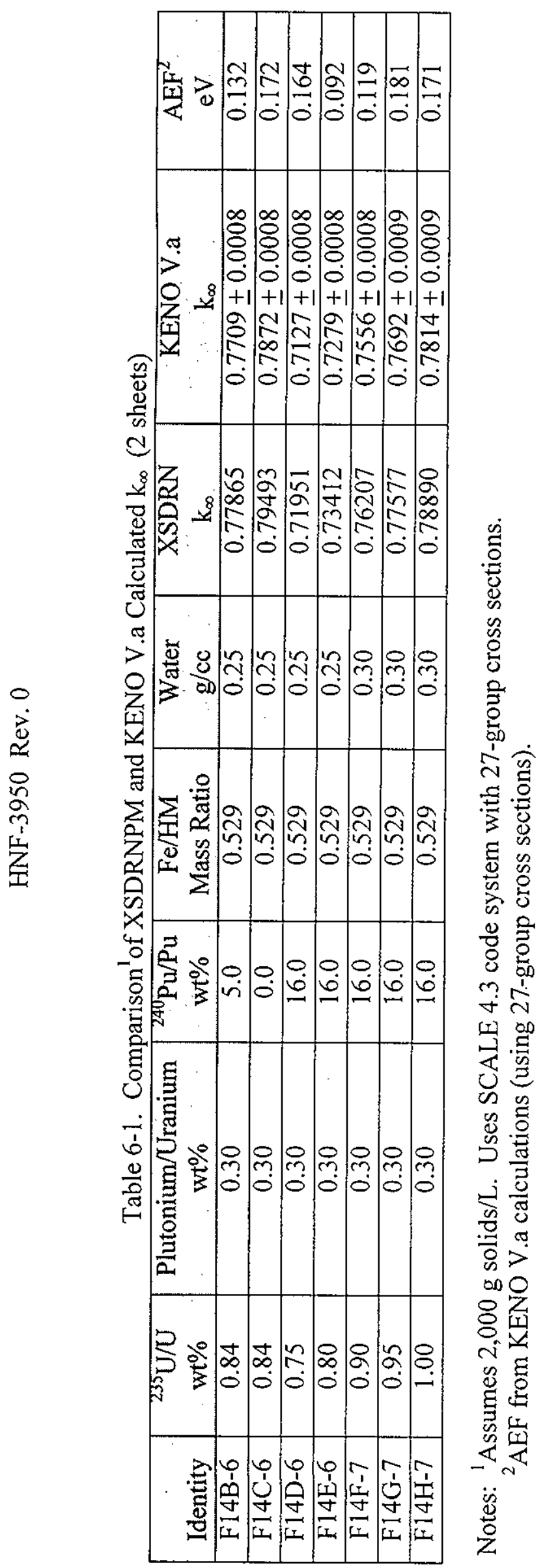




\subsection{COMPARISON BETWEEN CSAS1X AND STANDALONE XSDRNPM}

SCALE criticality modules can be executed either individually or using the CSAS sequences. Table 6-2 compares results from XSDRNPM executed individually with results from the CSAS1X sequence. Typical K Basin sludge compositions were selected for this comparison. For the individually executed XSDRNPM cases, cross sections are processed only in NITAWL. However, the CSAS1X sequence processes the cross sections first in BONAMI and then in NITAWL before calculating $\mathrm{k}_{\infty}$ using XSDRNPM. Table 6-2 shows that the difference between the standalone and CSAS1X results is minimal for calculations with the 27-group cross sections $(<0.0003 \Delta \mathrm{k})$. When 44-group cross sections are used, the difference is slightly larger $(<0.0042$ $\Delta \mathrm{k}$ ). This larger difference for the 44-group cross sections is not unexpected since the 27 -group library does not contain any Bondarenko data, and is not processed in BONAMI. However, the 44-group library does contain Bondarenko data for some isotopes and is processed in BONAMI when the CSAS1X sequence is executed.

\subsection{COMPARISON TO BENCHMARK EXPERIMENTS AND HANDBOOK DATA}

This section compares results from XSDRNPM calculations with published criticality data for infinite homogeneous mixtures of low enriched uranium, plutonium, and water. Calculations in this section were executed in the standalone mode using the 27-group cross-section set.

\subsubsection{Minimum Critical Plutonium Concentration in Water}

Paxton and Pruvost (1987) state that a limiting critical concentration of $7.6 \mathrm{~g}{ }^{239} \mathrm{Pu} / \mathrm{L}$ was deduced at the Hanford Site from experiments with a critical plutonium solution in a $4-\mathrm{ft}-$ diameter sphere. This limiting concentration compares to a value of $8.0 \mathrm{~g}{ }^{239} \mathrm{Pu} / \mathrm{L}$ as originally obtained from a Hanford Physical Constants Test Reactor (PCTR) measurement and which was later reduced to $7.2 \mathrm{~g}{ }^{239} \mathrm{Pu} / \mathrm{L}$ in a reexamination of the data.

The Criticality Handbook (Carter et al. 1969) provides a value of $7.8 \pm 0.3 \mathrm{~g} / \mathrm{L}$ for the minimum critical concentration of plutonium in an aqueous solution. This corresponds to an $\mathrm{H} / \mathrm{Pu}$ atom ratio of $3392 \pm 100$.

XSDRNPM calculations of $\mathrm{k}_{\infty}$ for plutonium oxide as a function of plutonium concentration in water are shown in Figure 6-1. For plutonium containing no ${ }^{240} \mathrm{Pu}$, criticality occurs when the plutonium concentration is $7.1 \mathrm{~g} \mathrm{Pu} / \mathrm{L}$. This agrees with the value of $7.2 \mathrm{~g}{ }^{239} \mathrm{Pu} / \mathrm{L}$ provided by Paxton and Pruvost (1987).

Figure 6-1 also shows the calculated $\mathrm{k}_{\infty}$ for plutonium oxide when the ${ }^{240} \mathrm{Pu}$ content is 5,10 , and $15 \mathrm{wt} \%$ of the plutonium. No experimental values were found for these three curves.

Nevertheless, they do show the degree to which ${ }^{240} \mathrm{Pu}$ influences $\mathrm{k}_{\infty}$. 
HNF-3950 Rev. 0

Table 6-2. Comparison of XSDRNPM and CSAS1X Calculated $\mathrm{k}_{\infty}$

\begin{tabular}{|l|c|c|c|c|c|}
\hline & $\begin{array}{c}\text { Cross Section } \\
\text { Gescription }\end{array}$ & $\begin{array}{c}\mathrm{k}_{\infty} \\
\text { XSDRNPM }\end{array}$ & CSAS1X & Ak \\
\hline $\begin{array}{l}\text { Model of Tank Farm sludge with } 0.84 \text { wt } \%{ }^{235} \mathrm{U}, \\
0.30 \mathrm{wt} \% \mathrm{Pu} / \mathrm{U}, 16.0 \mathrm{wt} \%{ }^{240} \mathrm{Pu} / \mathrm{Pu},\end{array}$ & 27 & 0.676459 & 0.676664 & -0.0002 \\
\hline $0.707 \mathrm{Fe} / \mathrm{HM}$ mass ratio, and optimal water. & 44 & 0.686756 & 0.682600 & $-0.0303 \%$ \\
\hline $\begin{array}{l}\text { Model of Tank Farm sludge with } 0.84 \mathrm{wt} \%{ }^{235} \mathrm{U}, \\
0.30 \mathrm{wt} \% \mathrm{Pu} / \mathrm{U}, 16.0 \mathrm{wt} \%{ }^{240} \mathrm{Pu} / \mathrm{Pu},\end{array}$ & 27 & 1.035140 & 1.035420 & -0.0042 & $0.5295 \%$ \\
\hline $0.000 \mathrm{Fe} / \mathrm{HM}$ mass ratio, and optimal water. & 44 & 1.041160 & 1.042730 & $-0.0270 \%$ \\
\hline
\end{tabular}




\subsubsection{Comparison to Criticality Handbook Data}

This section compares XSDRNPM calculated $\mathrm{k}_{\infty}$ with values from the Criticality Handbook (Carter et al. 1969). Calculations for the Criticality Handbook were produced using the GAMTEC-II and HFN codes. The GAMTEC-II code was used to provide 18 neutron energy group cross-section sets which were used in the HFN multigroup one-dimensional diffusion theory code to calculate critical sizes, extrapolation distances and material bucklings. A thorough analysis was made by C. R. Richey (1968) using this method to calculate the effective multiplication factor for critical experiments. Carter et al. (1969) report 11 calculations by Richey (1968). For nine spheres $\mathrm{k}_{\text {eff }}$ values are well within 1.0 percent of the experimental values. For two short cylinders calculated $\mathrm{k}_{\mathrm{eff}} \mathrm{s}$ are low by 1.5 percent and 2.5 percent. For GAMTEC-II - HFN calculations Carter et al. (1969) conclude that the comparison with experiment shows that this can be slightly non-conservative. Dimensions, which are less than can be obtained with some degree of confidence, can be obtained by reducing the calculated critical values to values equivalent to $\mathrm{k}_{\text {eff }}$ equal to 0.986 for spheres and 0.980 for infinite slabs and cylinders.

\subsubsection{1 $\mathrm{PuO}_{2}$ in Water}

Figure 6-2 shows a comparison between XSDRNPM calculated $\mathrm{k}_{\infty}$ and values from the Criticality Handbook. The comparison is made for an infinite homogeneous volume of $\mathrm{PuO}_{2}$ in water at concentrations ranging from 10 to $30 \mathrm{~g}$ plutonium/liter and for ${ }^{240} \mathrm{Pu}$ contents of $0,5,10$, and $15 \mathrm{wt} \%$ of the plutonium. Criticality Handbook data is taken from: (1) Figure III.A.10.1004 for plutonium metal with no ${ }^{240} \mathrm{Pu}$; (2) Figure III.A. 10.95-4 for plutonium metal with $5 \mathrm{wt} \%$ ${ }^{240} \mathrm{Pu}$; (3) Figure III.A.10(85)-2 for plutonium nitrate with $15 \mathrm{wt} \%{ }^{240} \mathrm{Pu}$; and (4) Figure III.A.10(90)-2 for plutonium nitrate with $10 \mathrm{wt} \%{ }^{240} \mathrm{Pu}$. Although the XSDRNPM calculations were for plutonium oxide in water, the handbook data is for plutonium metal in water and plutonium nitrate systems. In all cases the volume ratio of water to plutonium compound is large, and the difference in plutonium compounds has only a very small effect on $\mathrm{k}_{\infty}$.

Over the range of plutonium concentration and ${ }^{240} \mathrm{Pu}$ content examined XSDRNPM calculates $\mathrm{k}_{\infty}$ about 1.0 percent larger than the handbook value. The slightly poorer agreement at higher plutonium concentration may reflect the small, but increasing, differences in the systems being compared.

\subsubsection{2 $1.25 \mathrm{wt}^{\circ} \% \mathrm{UO}_{2}$ in Water}

Figure 6-3 shows XSDRNPM calculations for $1.25 \mathrm{wt} \% \mathrm{UO}_{2}$ in water. This can be compared with Figure III.B.10(1.25)-2 in the Criticality Handbook, which shows a curve of $\mathrm{k}_{\infty}$ for $1.25 \mathrm{wt} \%$ uranium trioxide as a function of concentration in water. A maximum $\mathrm{k}_{\infty}$ of 1.062 is achieved when the uranium concentration is $3100 \mathrm{~g} / \mathrm{L}$. XSDRNPM calculations for $1.25 \mathrm{wt} \%$ uranium dioxide in water provides a maximum $\mathrm{k}_{\infty}$ of 1.0615 . 
HNF-3950 Rev. 0

Figure 6-1. $\mathrm{k}_{\infty}$ or Homogeneous $\mathrm{PuO}_{2}$ in Water

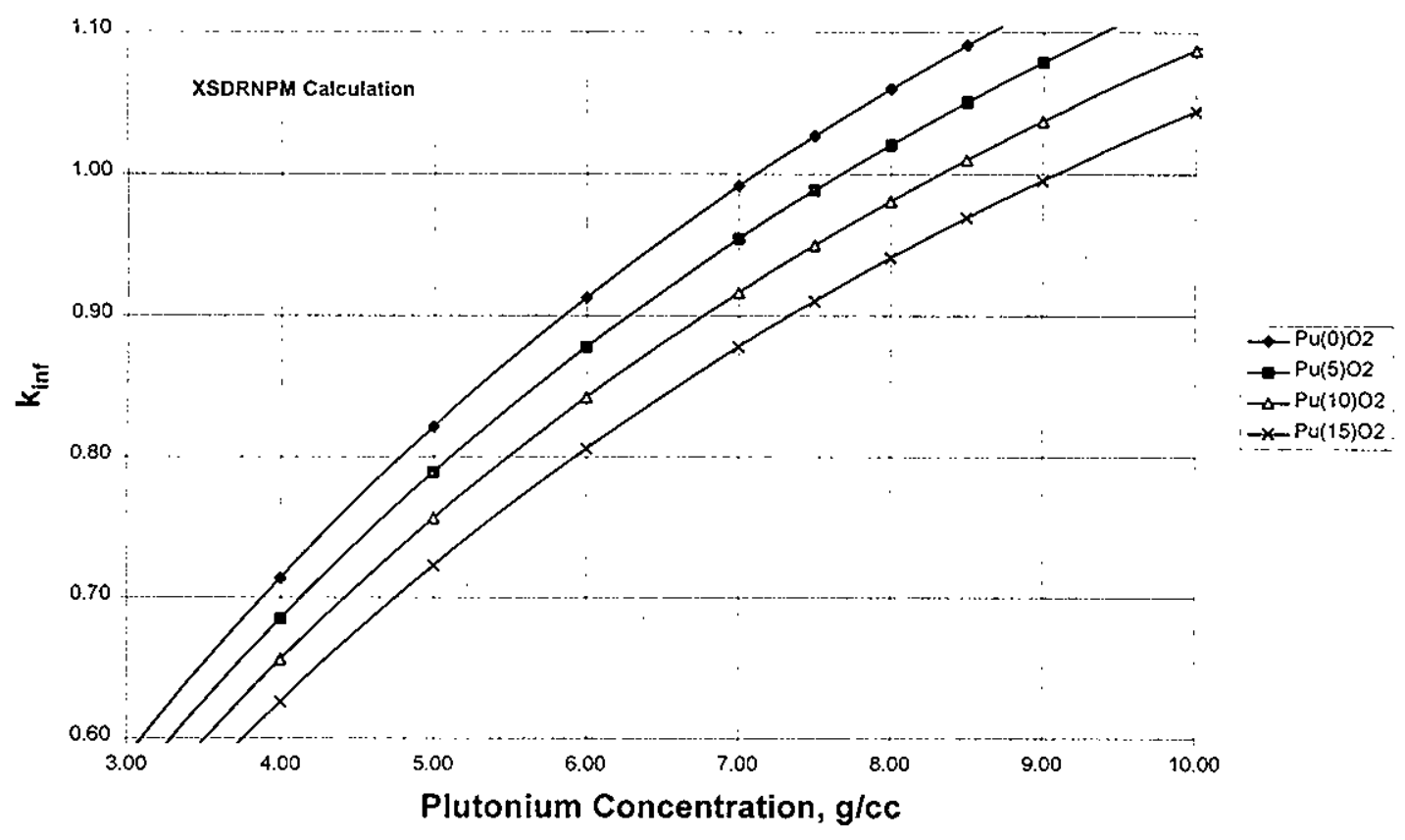

Figure 6-2. Comparison of XSDRNPM with Criticality Handbook for $\mathrm{PuO}_{2}$ in Water

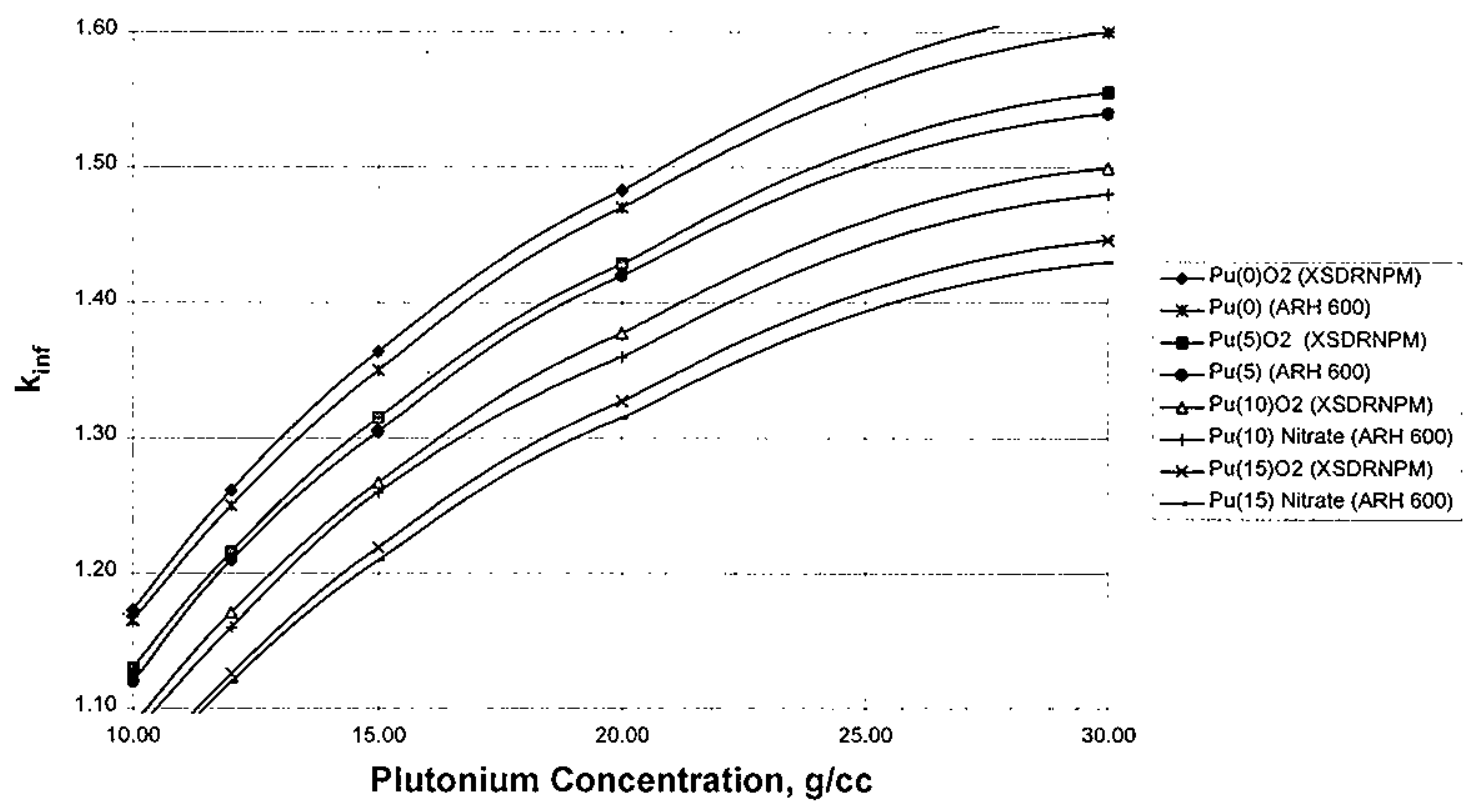


HNF-3950 Rev. 0

Figure 6-3. XSDRNPM $\mathrm{k}_{\infty}$ or Homogeneous $\mathrm{U}(1.25) \mathrm{O}_{2}$ in Water

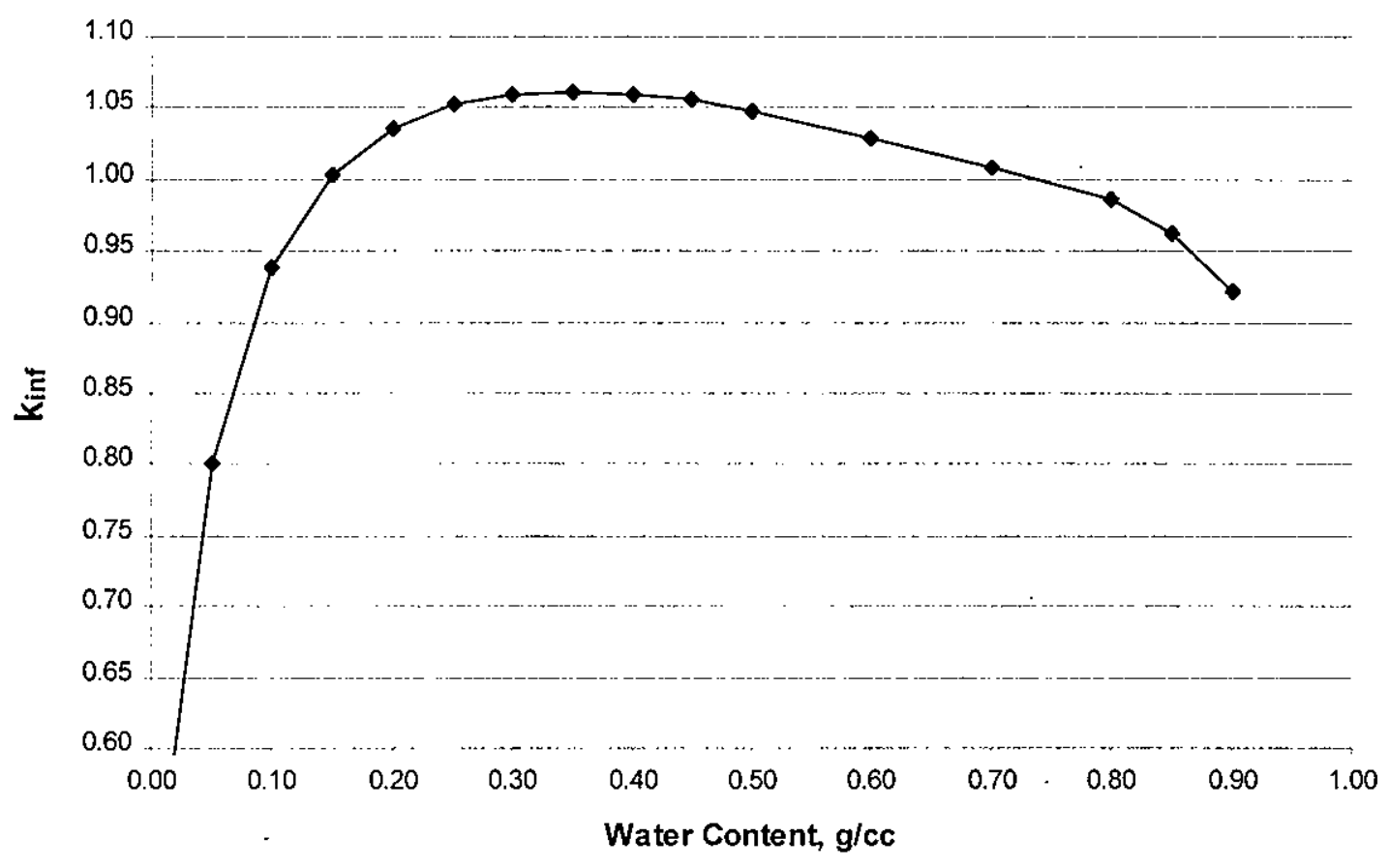




\subsection{DISCUSSION}

Table 7-1 shows the results from a statistical analysis of the results presented in Tables 5-1 through 5-5. The experiments are grouped and analyzed according to fissile isotope, thermal systems, fast systems, all systems, and systems with iron. Within each group, the results are subdivided according to cross section set. The results are correlated against key parameters in each group. Table 7-1 lists the linear regression analysis results, average calculated $\mathrm{k}_{\mathrm{eff}}$, standard deviation, and $\mathrm{USL}_{1}$ and $\mathrm{USL}_{2}$ values (see Section 4.0 for description) for each statistical analysis. All positive biases are conservatively set to zero.

$\mathrm{USL}_{1}$ and $\mathrm{USL}_{2}$ values are shown in Table 7-1 for a variety of experiment groupings. This provides information to validate XSDRNPM for future criticality safety evaluations that might involve configurations different from $\mathrm{K}$ Basin sludge. For example, ${ }^{233} \mathrm{U}$ benchmarks were calculated and are included in Table $7-1$, but these are not used in the determination of the USL for K Basin sludge.

As mentioned previously, XSDRNPM will be used to calculate configurations of tank waste. A composition of primary interest is that of $\mathrm{K}$ Basin sludge composed of irradiated low enriched uranium and plutonium mixed with iron and water. Plutonium generated during irradiation of uranium is assumed to remain associated with the uranium. The highest ${ }^{235} \mathrm{U}$ enrichment is taken to be $1.25 \mathrm{wt} \%$, the highest enrichment in any uranium in tank waste before irradiation. During the process of irradiation the ${ }^{235} \mathrm{U}$ enrichment decreases, and much of the actual uranium in tank waste is depleted. However, the plutonium content can be as much as $0.30 \mathrm{wt} \%$ of the uranium. Scenarios are to be evaluated in which the plutonium is chemically separated from the uranium and is deposited at a higher concentration in a different location. The effect of neutron absorbing solids, especially iron, on the neutron multiplication constant are of interest.

For calculational models the plutonium is assumed composed of the ${ }^{239} \mathrm{Pu}$ and the ${ }^{240} \mathrm{Pu}$ isotopes. Although ${ }^{238} \mathrm{Pu},{ }^{241} \mathrm{Pu}$, and ${ }^{242} \mathrm{Pu}$ are present, these isotopes are of lesser importance to criticality safety and are not taken into account specifically in calculations. In practice, calculations may be made with ${ }^{238} \mathrm{Pu}$ and ${ }^{242} \mathrm{Pu}$ replaced by

${ }^{240} \mathrm{Pu}$ or replaced by ${ }^{239} \mathrm{Pu}$, which is more conservative. The worth of ${ }^{241} \mathrm{Pu}$ can be twice as much as ${ }^{239} \mathrm{Pu}$. A discussion of the significance of these isotopes should be provided in criticality safety evaluations.

Iron is added to sludge to ensure long-term chemical compatibility and subcriticality. The iron content may be quite high, and the $\mathrm{Fe} / \mathrm{Pu}$ and the $\mathrm{Fe} /{ }^{235} \mathrm{U}$ mass ratios might exceed 300 . No restriction is placed upon the water content, and water is assumed to range from none to a large fraction of the sludge volume. The configuration of interest to criticality safety are those which result in the largest $\mathrm{k}_{\infty}$.

\subsection{SUMMARY OF USL RESULTS}

Table 7-1 summarizes USL calculations for benchmark experiments grouped according to various parameters. Four primary groups contain calculations of experiments with specific components: ${ }^{233} \mathrm{U},{ }^{235} \mathrm{U}$, plutonium, and iron. Two primary groups include all component types, but separate configuration according to whether they are thermal or fast, and one primary group includes all calculations for both thermal and fast systems. These calculations were made using XSDRNPM. The final primary group contains KENO V.a calculations of experiments containing iron. Each primary group is subdivided according to 27-group or 44-group cross sections. 


\subsubsection{USL for all Solution Systems $\left({ }^{233} \mathrm{U},{ }^{235} \mathrm{U}\right.$, and $\left.\mathrm{Pu}\right)$}

For a grouping that includes all solution systems (AEF from 0.029 to $0.344 \mathrm{eV}$ ) for ${ }^{233} \mathrm{U},{ }^{235} \mathrm{U}$ and plutonium, the minimum USL $_{1}$ with a 0.05 administrative margin is 0.923 for 27 -group cross sections and 0.930 for 44 group cross sections. The minimum $\mathrm{USL}_{2}$ for this grouping of solution systems is 0.939 for 27 -group cross sections and 0.955 for 44 -group cross sections. USL 2 is found to be larger than USL 1 for both cross section sets. This indicates that a 0.05 administrative margin applied to $\mathrm{USL}_{1}$ is adequate for thermal systems as long as the AEF falls within the applicable range (i.e., the correlated parameter is not extrapolated). When the H/X ratio falls between 125 and 3694 , the $\mathrm{AEF}$ is assured of falling within the applicable range. It should be noted, however, that configurations with an $\mathrm{H} / \mathrm{X}$ ratio less than 125 can also fall within the applicable AEF range, if additional moderation is provided by other materials.

\subsubsection{USL for Thermal Systems $\left({ }^{235} \mathrm{U}\right.$ and $\left.\mathrm{Pu}\right)$}

For a grouping that includes all ${ }^{235} \mathrm{U}$ and plutonium thermal systems, including moderated ${ }^{235} \mathrm{U}$ lattices, the minimum USL $\mathrm{U}_{1}$ with a 0.05 administrative margin is 0.934 for 27 -group cross sections and 0.932 for 44 -group cross sections. The minimum USL 2 for this grouping is 0.954 for 27 -group cross sections and 0.947 for $44-$ group cross sections. When ${ }^{235} \mathrm{U}$ lattices are not included, the minimum USL $\mathrm{U}_{1}$ is 0.931 for 27 -group cross sections and 0.934 for 44 -group cross sections, and the minimum USL $_{2}$ is 0.0943 for 27 -group cross sections and 0.953 for 44 -group cross sections. The AEF for this grouping ranges from 0.029 to $0.344 \mathrm{eV}$.

\subsubsection{USL for K Basin Sludge Analysis}

Key configurations of $\mathrm{K}$ Basin sludge for which water content is optimized to provide maximum $\mathrm{k}_{\infty}$ are shown in Table 6-1. These configurations are thermal systems with the AEF ranging from 0.092 to $0.188 \mathrm{eV}$. Configurations with an iron/uranium mass ratio even higher than shown in this table (i.e., greater than 0.707) may be calculated for the evaluation of $\mathrm{K}$ Basin sludge. These configurations will nevertheless be thermal systems whose AEF will fall within the range of applicability of this evaluation.

Table 7-1 shows homogeneous systems in which the iron-to-heavy metal (Fe/HM) mass ratio ranges from 0.002 to 0.446 . When the administrative margin is 0.05 , the minimum USL $\mathrm{UL}_{1}$ is 0.933 with 27 -group cross sections and 0.926 for 44-group cross sections, and the minimum $\mathrm{USL}_{2}$ is 0.937 for 27 -group cross sections and 0.912 for 44-group cross sections. For the 44-group cross sections $\mathrm{USL}_{2}$ is smaller than $\mathrm{USL}_{1}$. Since the method used to determine $\mathrm{USL}_{2}$ calculates its own administrative margin, this indicates that the administrative margin applied to $\mathrm{USL}_{1}$ should be larger than 0.05 for 44 -group cross section calculations. The confidence in the 0.05 administrative margin is also brought into question when considering that only two of the XSDRNPM benchmarks are for thermal systems, and the Fe/HM ratio is well below 0.70 , the approximate iron content expected $\mathrm{K}$ Basin sludge when received at tank farms. Therefore, based on the consideration of iron, it is recommended than an administrative margin of 0.10 be used for the criticality safety evaluation of $\mathrm{K}$ Basin sludge in the Hanford Site waste tank

To increase the confidence in the iron cross sections for thermal systems, KENO V.a calculations for heterogeneous plate experiments were analyzed statistically. For these experiments the AEF ranged from 0.073 to 0.233 , and the Fe/HM mass ratio ranged from 0.0 to 0.103 . For and administrative margin of 0.05 the minimum USL $_{1}$ is 0.936 for 27 -group cross sections and 0.941 for 44 -group cross sections, and the minimum 
$\mathrm{USL}_{2}$ is 0.968 for 27 -group cross sections and 0.974 for 44 -group cross sections. This indicates that administrative margin of 0.05 is adequate for systems that fall within this range of benchmark experiments. However, the energy spectrum that the iron encounters in a heterogeneous thermal system is expected to be somewhat different than the spectrum encountered in a homogenous thermal system. In addition, the upper limit of the range of $\mathrm{Fe} / \mathrm{HM}$ mass ratio covered in these experiments is much less than the values expected for $\mathrm{K}$ Basin sludge. In conclusion, although KENO V.a calculations support a 0.05 administrative margin for the range of iron content in available experiments, this range is not broad enough to support a margin of 0.05 for $\mathrm{K}$ Basin sludge. 
Table 7-1. Summary of Upper Safety Limit Calculations. (3 sheets)

\begin{tabular}{|c|c|c|c|c|c|c|c|c|c|c|c|c|}
\hline Set $^{1}$ & $\begin{array}{l}\text { Cross } \\
\text { Section } \\
\text { Group }\end{array}$ & Correlated Parameter $(\mathrm{x})$ & $\begin{array}{c}\text { No } \\
\text { Exps. }\end{array}$ & $\mathrm{K}_{\mathrm{c}}(\mathrm{x})$ Linear Regression & $\begin{array}{l}\text { Std. } \\
\text { Dev. }\end{array}$ & $\begin{array}{c}\text { Corr. } \\
\text { Coef. } \\
r^{2}\end{array}$ & $\begin{array}{c}\text { Average } \\
\mathrm{k}_{\mathrm{c}}\end{array}$ & W & $\begin{array}{c}\text { Min } \\
\text { USL }_{1} \\
\left(\Delta \mathrm{k}_{\mathrm{m}}\right. \\
=0.05)\end{array}$ & $\begin{array}{c}\text { Min } \\
\mathrm{USL}_{1} \\
\left(\Delta \mathrm{k}_{\mathrm{m}}\right. \\
=0.10)\end{array}$ & $\begin{array}{l}\mathrm{Min}_{\mathrm{USL}} \\
\mathrm{USL_{2 }}\end{array}$ & $\begin{array}{c}\mathrm{Min} \\
\Delta \mathrm{k}_{\mathrm{m}} \\
\mathrm{USL}_{2}\end{array}$ \\
\hline${ }^{233} \mathrm{U}$ & 27 & AEF ( ${ }^{233} U$ - thermal) & 2 & Insufficient Data & & & & & & & & \\
\hline \multirow[t]{5}{*}{ Exps } & & $\operatorname{AEF}\left({ }^{233} U\right.$ - fast $)$ & 11 & $1.0293+(-5.4695 \mathrm{E}-08) * \mathrm{x}$ & 0.0058 & 0.582 & 0.97820 & 0.0125 & 0.908 & 0.858 & 0.934 & 0.023 \\
\hline & & AEF $\left({ }^{233} U-\right.$ all $)$ & 13 & $1.0211+(-4.5997 \mathrm{E}-08) * \mathrm{x}$ & 0.0060 & 0.898 & 0.98470 & 0.0130 & 0.908 & 0.858 & 0.936 & 0.022 \\
\hline & 44 & AEF ( ${ }^{233} \mathrm{U}$ - thermal) & 2 & Insufficient Data & & & & & & & & \\
\hline & & $\operatorname{AEF}\left({ }^{233} U\right.$ - fast $)$ & 11 & $1.0202+(-1.9917 \mathrm{E}-08)^{*} \mathrm{x}$ & 0.0046 & 0.222 & 1.00157 & 0.0100 & 0.939 & 0.889 & 0.970 & 0.019 \\
\hline & & $\operatorname{AEF}\left({ }^{233} U-\right.$ all $)$ & 13 & $1.0074+(-6.4425 \mathrm{E}-09)^{*} \mathrm{x}$ & 0.0056 & 0.164 & 1.00232 & 0.0121 & 0.938 & 0.888 & 0.967 & 0.021 \\
\hline${ }^{235} \mathrm{U}$ & 27 & AEF ${ }^{235}$ U lattices $)$ & 5 & $1.0159+(-1.0329 \mathrm{E}-02) * x$ & 0.0038 & 0.072 & 1.01387 & 0.0122 & 0.938 & 0.888 & 0.951 & 0.036 \\
\hline \multirow[t]{9}{*}{ Exps } & & AEF $\left({ }^{235} \mathrm{U}\right.$ - solutions $)$ & 5 & $1.0031+(-2.0248 \mathrm{E}-01) * \mathrm{x}$ & 0.0016 & 0.084 & 0.99670 & 0.0047 & 0.942 & 0.892 & 0.977 & 0.015 \\
\hline & & AEF $\left({ }^{235} U\right.$ - metal $)$ & 9 & $1.0252+(-2.8320 \mathrm{E}-08) * \mathrm{x}$ & 0.0163 & 0.282 & 1.01595 & 0.0372 & 0.913 & 0.863 & 0.888 & 0.075 \\
\hline & & $\mathrm{AEF}\left({ }^{235} \mathrm{U}-\mathrm{all}\right)$ & 19 & $1.0114+(-6.6349 \mathrm{E}-09) * \mathrm{x}$ & 0.0151 & 0.016 & 1.01034 & 0.0313 & 0.919 & 0.869 & 0.921 & 0.048 \\
\hline & & Enrichment $\left({ }^{235} \mathrm{U}-\right.$ all $)$ & 19 & $1.0121+(-3.3535 \mathrm{E}-03)^{*} \mathrm{x}$ & 0.0151 & 0.010 & 1.01034 & 0.0279 & 0.922 & 0.872 & 0.929 & 0.043 \\
\hline & 44 & AEF ( ${ }^{235}$ U lattices) & 5 & $1.0221+(4.9197 \mathrm{E}-03)^{*} \mathrm{x}$ & 0.0043 & 0.014 & 1.02307 & 0.0138 & 0.936 & 0.886 & 0.945 & 0.041 \\
\hline & & AEF $\left({ }^{235} U-\right.$ solutions $)$ & 5 & $1.0114+(-4.4771 \mathrm{E}-01)^{*} \mathrm{x}$ & 0.0011 & 0.439 & 0.99720 & 0.0034 & 0.943 & 0.893 & 0.982 & 0.011 \\
\hline & & $\operatorname{AEF}\left({ }^{235} U-\right.$ metal $)$ & 9 & $1.0142+(-1.0024 \mathrm{E}-08) * \mathrm{x}$ & 0.0090 & 0.140 & 1.01090 & 0.0205 & 0.930 & 0.880 & 0.938 & 0.041 \\
\hline & & $\operatorname{AEF}\left({ }^{235} \mathrm{U}-\mathrm{all}\right)$ & 19 & $1.0114+(-5.6257 \mathrm{E}-09) * \mathrm{x}$ & 0.0118 & 0.019 & 1.01050 & 0.0244 & 0.926 & 0.876 & 0.939 & 0.037 \\
\hline & & Enrichment $\left({ }^{235} U-\right.$ all $)$ & 19 & $1.0232+(-2.4088 \mathrm{E}-02) * \mathrm{x}$ & 0.0044 & 0.863 & 1.01050 & 0.0081 & 0.942 & 0.892 & 0.979 & 0.013 \\
\hline \multirow[t]{6}{*}{ Pu Exps } & 27 & $\begin{array}{l}\text { AEF (Pu - moderated) } \\
\text { AEF (Pu - fast) }\end{array}$ & $\begin{array}{c}10 \\
4\end{array}$ & $\begin{array}{l}1.0109+(1.8944 \mathrm{E}-02)^{*} \mathrm{X} \\
\text { Insufficient Data }\end{array}$ & 0.0068 & 0.089 & 1.01289 & 0.0157 & 0.934 & 0.884 & 0.955 & 0.030 \\
\hline & & $\operatorname{AEF}(\mathrm{Pu}-\mathrm{all})$ & 14 & $1.0135+(-7.7141 \mathrm{E}-09)^{*} \mathrm{x}$ & 0.0070 & 0.154 & 1.01229 & 0.0159 & 0.934 & 0.884 & 0.958 & 0.026 \\
\hline & & ${ }^{240} \mathrm{Pu}$ wt $\%(\mathrm{Pu}-\mathrm{all})$ & 14 & $1.0133+(-1.4462 \mathrm{E}-02) * \mathrm{x}$ & 0.0074 & 0.045 & 1.01229 & 0.0184 & 0.932 & 0.882 & 0.953 & 0.029 \\
\hline & 44 & $\begin{array}{l}\mathrm{AEF}(\mathrm{Pu} \text { - moderated) } \\
\mathrm{AEF}(\mathrm{Pu} \text { - fast) }\end{array}$ & $\begin{array}{c}10 \\
4\end{array}$ & $\begin{array}{l}1.0073+(3.9334 \mathrm{E}-03) * \mathrm{x} \\
\text { Insufficient Data }\end{array}$ & 0.0069 & 0.004 & 1.00772 & 0.0157 & 0.934 & 0.884 & 0.955 & 0.030 \\
\hline & & $\mathrm{AEF}(\mathrm{Pu}-$ all $)$ & 14 & $1.0097+(-6.4483 \mathrm{E}-09) * x$ & 0.0099 & 0.059 & 1.00872 & 0.0226 & 0.927 & 0.877 & 0.941 & 0.037 \\
\hline & & ${ }^{240} \mathrm{Pu}$ wt $\%(\mathrm{Pu}-$ all $)$ & 14 & $1.0093+(-8.2846 \mathrm{E}-03) * \mathrm{x}$ & 0.0102 & 0.008 & 1.00872 & 0.0253 & 0.925 & 0.875 & 0.935 & 0.040 \\
\hline
\end{tabular}


HNF-3950 Rev. 0

Table 7-1. Summary of Upper Safety Limit Calculations. (3 sheets)

\begin{tabular}{|c|c|c|c|c|c|c|c|c|c|c|c|c|}
\hline Set & $\begin{array}{l}\text { Cross } \\
\text { Section } \\
\text { Group }\end{array}$ & Correlated Parameter $(\mathrm{x})$ & $\begin{array}{l}\text { No } \\
\text { Exps }\end{array}$ & $K_{c}(x)$ Linear Regression & $\begin{array}{l}\text { Std. } \\
\text { Dev. }\end{array}$ & $\begin{array}{c}\text { Corr. } \\
\text { Coef } \\
r^{2}\end{array}$ & $\begin{array}{c}\text { Average } \\
\mathrm{k}_{\mathrm{c}}\end{array}$ & W & $\begin{array}{c}\text { Min } \\
\text { USL }_{1} \\
\left(\Delta \mathrm{k}_{\mathrm{m}}\right. \\
=0.05)\end{array}$ & $\begin{array}{c}\text { Min } \\
\mathrm{USL}_{\mathrm{l}} \\
\left(\Delta \mathrm{k}_{\mathrm{m}}\right. \\
=0.10)\end{array}$ & $\underset{\mathrm{USL}_{2}}{\mathrm{Min}}$ & $\begin{array}{l}\operatorname{Min} \\
\Delta \mathrm{k}_{\mathrm{m}} \\
\mathrm{USL}_{2}\end{array}$ \\
\hline \multirow[t]{14}{*}{$\begin{array}{l}\text { Thermal } \\
\text { Exps }\end{array}$} & \multirow[t]{7}{*}{27} & $\begin{array}{l}\mathrm{H} / \mathrm{X} \text { Ratio }(\mathrm{H} / \mathrm{X}>100-\text { all } \\
\text { solutions) }\end{array}$ & 17 & $1.0143+(-5.1756 \mathrm{E}-06)^{*} \mathrm{x}$ & 0.0096 & 0.171 & 1.00901 & 0.0221 & 0.923 & 0.873 & 0.939 & 0.034 \\
\hline & & AEF $\left({ }^{235} \mathrm{U}\right.$ lattices $)$ & 5 & $1.0159+(-1.0329 \mathrm{E}-02)^{*} \mathrm{x}$ & 0.0038 & 0.072 & 1.01387 & 0.0122 & 0.938 & 0.888 & 0.951 & 0.036 \\
\hline & & AEF ( ${ }^{235} \mathrm{U}$ solutions $)$ & 5 & $1.0031+(-2.0248 \mathrm{E}-01)^{*} \mathrm{x}$ & 0.0016 & 0.084 & 0.99670 & 0.0047 & 0.942 & 0.892 & 0.977 & 0.015 \\
\hline & & AEF (Pu soltions) & 10 & $1.0109+(1.8944 \mathrm{E}-02) * \mathrm{x}$ & 0.0068 & 0.089 & 1.01289 & 0.0157 & 0.934 & 0.884 & 0.955 & 0.030 \\
\hline & & AEF (Pu \& ${ }^{235} \mathrm{U}$ solutions) & 15 & $1.0035+(4.9090 \mathrm{E}-02) * x$ & 0.0088 & 0.357 & 1.00749 & 0.0191 & 0.931 & 0.881 & 0.943 & 0.038 \\
\hline & & AEF (Pu \& ${ }^{235}$ U systems) & 20 & $1.0046+(4.1254 \mathrm{E}-02) * \mathrm{x}$ & 0.0080 & 0.283 & 1.00909 & 0.0159 & 0.934 & 0.884 & 0.954 & 0.030 \\
\hline & & AEF (all isotopes) & 22 & $1.0066+(3.3933 \mathrm{E}-02) * \mathrm{x}$ & 0.0089 & 0.133 & 1.01012 & 0.0175 & 0.933 & 0.883 & 0.957 & 0.026 \\
\hline & \multirow[t]{7}{*}{44} & $\begin{array}{l}\mathrm{H} / \mathrm{X} \text { Ratio }(\mathrm{H} / \mathrm{X}>100-\text { all } \\
\text { isotopes) }\end{array}$ & 17 & $1.0073+(-2.7237 \mathrm{E}-06)^{*} \mathrm{x}$ & 0.0073 & 0.089 & 1.00447 & 0.0169 & 0.930 & 0.880 & 0.955 & 0.026 \\
\hline & & AEF $\left({ }^{235} \mathrm{U}\right.$ lattices $)$ & 5 & $1.0221+(4.9197 \mathrm{E}-03) * \mathrm{x}$ & 0.0043 & 0.014 & 1.02307 & 0.0138 & 0.936 & 0.886 & 0.945 & 0.041 \\
\hline & & AEF $\left({ }^{235} \mathrm{U}\right.$ solutions $)$ & 5 & $1.0114+(-4.4771 \mathrm{E}-01) * x$ & 0.0011 & 0.439 & 0.99720 & 0.0034 & 0.943 & 0.893 & 0.982 & 0.011 \\
\hline & & AEF (Pu solutions) & 10 & $1.0073+(3.9334 \mathrm{E}-03) * \mathrm{x}$ & 0.0069 & 0.004 & 1.00772 & 0.0157 & 0.934 & 0.884 & 0.955 & 0.030 \\
\hline & & AEF (Pu \& ${ }^{235} \mathrm{U}$ solutions) & 15 & $1.0022+(2.4748 \mathrm{E}-02) * \mathrm{x}$ & 0.0072 & 0.288 & 1.00421 & 0.0158 & 0.934 & 0.884 & 0.953 & 0.031 \\
\hline & & AEF (Pu \& ${ }^{235}$ U systems) & 20 & $1.0027+(5.6254 \mathrm{E}-02) * \mathrm{x}$ & 0.0091 & 0.019 & 1.00893 & 0.0182 & 0.932 & 0.882 & 0.947 & 0.034 \\
\hline & & AEF (all isotopes) & 22 & $1.0029+(5.5356 \mathrm{E}-02) * \mathrm{x}$ & 0.0091 & 0.281 & 1.00870 & 0.0179 & 0.932 & 0.882 & 0.956 & 0.026 \\
\hline \multirow{6}{*}{$\begin{array}{l}\text { Fast } \\
\text { Exps }\end{array}$} & \multirow[t]{3}{*}{27} & $\mathrm{AEF}\left({ }^{233} \mathrm{U}\right.$ fast $)$ & 11 & $1.0293+(-5.4695 \mathrm{E}-08) * \mathrm{x}$ & 0.0058 & 0.582 & 0.97820 & 0.0125 & 0.908 & 0.858 & 0.934 & 0.023 \\
\hline & & $\operatorname{AEF}\left({ }^{235} \mathrm{U}-\right.$ metal $)$ & 9 & $1.0252+(-2.8320 \mathrm{E}-08) * \mathrm{x}$ & 0.0163 & 0.282 & 1.01595 & 0.0372 & 0.913 & 0.863 & 0.888 & 0.075 \\
\hline & & AEF (all isotopes) & 24 & $1.0252+(-4.2662 \mathrm{E}-08)^{*} \mathrm{x}$ & 0.0142 & 0.523 & 0.99779 & 0.0262 & 0.900 & 0.850 & 0.912 & 0.038 \\
\hline & \multirow[t]{3}{*}{44} & $\operatorname{AEF}\left({ }^{233} \mathrm{U}\right.$ fast $)$ & 11 & $1.0202+(-1.9917 \mathrm{E}-08) * \mathrm{x}$ & 0.0046 & 0.222 & 1.00157 & 0.0100 & 0.939 & 0.889 & 0.970 & 0.019 \\
\hline & & $\operatorname{AEF}\left({ }^{235} \mathrm{U}\right.$ - metal $)$ & 9 & $1.0142+(-1.0024 \mathrm{E}-08) * \mathrm{x}$ & 0.0090 & 0.140 & 1.01090 & 0.0205 & 0.930 & 0.880 & 0.938 & 0.041 \\
\hline & & AEF (all isotopes) & 24 & $1.0166+(-1.5412 \mathrm{E}-08) * \mathrm{x}$ & 0.0079 & 0.400 & 1.00668 & 0.0145 & 0.934 & 0.884 & 0.963 & 0.021 \\
\hline
\end{tabular}


HNF-3950 Rev. 0

Table 7-1. Summary of Upper Safety Limit Calculations. (3 sheets)

\begin{tabular}{|c|c|c|c|c|c|c|c|c|c|c|c|c|}
\hline Set $^{1}$ & $\begin{array}{l}\text { Cross } \\
\text { Section } \\
\text { Group }\end{array}$ & Correlated Parameter (x) & $\begin{array}{r}\text { No } \\
\text { Exps. }\end{array}$ & $\mathrm{k}_{\mathrm{c}}(\mathrm{x})$ Linear Regression & $\begin{array}{l}\text { Std. } \\
\text { Dev. }\end{array}$ & $\begin{array}{c}\text { Corr. }^{2} \\
\text { Coef. }^{2} \\
\mathrm{r}^{2}\end{array}$ & $\begin{array}{r}\text { Average } \\
\mathrm{k}_{\mathrm{c}}\end{array}$ & $\mathrm{W}$ & \begin{tabular}{|c|} 
Min \\
$U_{S L}$ \\
$\left(\Delta \mathrm{k}_{\mathrm{m}}\right.$ \\
$=0.05)$ \\
\end{tabular} & $\begin{array}{l}\text { Min } \\
\text { USL } \\
\left(\Delta \mathrm{k}_{\mathrm{m}}\right. \\
=0.10) \\
\end{array}$ & $\begin{array}{l}\mathrm{Min} \\
\mathrm{USL}\end{array}$ & $\begin{array}{l}\text { Min } \\
\Delta \mathrm{k}_{\mathrm{m}} \\
\mathrm{USL}\end{array}$ \\
\hline \multirow[t]{6}{*}{ All Exps } & \multirow[t]{3}{*}{27} & $\begin{array}{l}\text { AEG (all isotopes, } \\
\text { systems) }\end{array}$ & 46 & $0.9920+(5.2101 \mathrm{E}-04)^{*} \mathrm{x}$ & 0.0170 & 0.153 & 1.00369 & 0.0293 & 0.917 & 0.867 & 0.932 & 0.035 \\
\hline & & AEF (all $\mathrm{Pu}$ and ${ }^{235} \mathrm{U}$ ) & 33 & $1.0123+(-7.2158 \mathrm{H}$ & 0.0120 & 0.009 & 1.02227 & 0.0236 & 0.926 & 0.876 & 0.936 & 0.040 \\
\hline & & AEF (all isotopes, systems) & 46 & $1.0136+(-2$ & 0.0130 & 0.503 & 1.00369 & 0.0229 & 0.906 & 0.856 & 0.929 & 0.028 \\
\hline & \multirow[t]{3}{*}{44} & AEG (all isotor & 46 & $1.0062+(6.5973 \mathrm{E}-05)^{*} \mathrm{x}$ & 0.0102 & 0.008 & 1.00765 & 0.0176 & 0.932 & 0.882 & 0.962 & 0.021 \\
\hline & & AEF (all Pu and ${ }^{235} \mathrm{U}$ ) & 33 & $1.0107+(-6.0952 \mathrm{E}-09) * x$ & 0.0107 & 0.006 & 1.00974 & 0.0211 & 0.929 & 0.879 & 3 & 0.036 \\
\hline & & AEF (all isotopes, systems) & 46 & $1.0105+(-8.6221 \mathrm{E}-09)^{*} \mathrm{x}$ & 0.0095 & 0.139 & 1.00765 & $0.0167 \mid$ & 0.933 & 0.883 & 0.963 & 0.020 \\
\hline \multirow{3}{*}{\begin{tabular}{|l|}
$\mathrm{Fe}$ \\
XSDRN \\
Exps
\end{tabular}} & \multirow[t]{2}{*}{27} & $\begin{array}{l}\mathrm{Fe} / \text { HM Ratio } \\
\mathrm{Fe} / \mathrm{HM} \text { Ratio }\end{array}$ & $\begin{array}{l}2 \\
4\end{array}$ & $\begin{array}{l}\text { Insufficient Data } \\
\text { Insufficient Data }\end{array}$ & & & & & & & & \\
\hline & & Fe/HM Ratio & 6 & $1.0085+(2.4502 E-02) * x$ & 0.0066 & 0.454 & 1.01261 & 0.0173 & 0.933 & 883 & 937 & 0.046 \\
\hline & 44 & $\begin{array}{l}\text { Fe/HM Ratio (thermal) } \\
\text { Fe/HM Ratio (fast) } \\
\text { Fe/HM Ratio (all) }\end{array}$ & $\begin{array}{l}2 \\
4 \\
6\end{array}$ & $\begin{array}{l}\text { Insufficient Data } \\
\text { Insufficient Data } \\
1.0079+(5.1025 \mathrm{E}-02)^{*} \mathrm{x}\end{array}$ & 0092 & 650 & 46 & .0241 & 26 & 876 & 12 & \\
\hline \multirow{5}{*}{$\begin{array}{c}\mathrm{Fe} \\
\text { KENO } \\
\text { Plate } \\
\text { Exps }\end{array}$} & \multirow[t]{3}{*}{27} & Fe/HM Ratio $($ ratio $=0)$ & 2 & Insufficient Data & & & & & & & & \\
\hline & & Fe/HM Ratio (ratio >0) & 8 & $0.9944+(7.1629$ & 0.0036 & 0.007 & 0.99475 & 0.0085 & 0.936 & 0.886 & 0.968 & 0.018 \\
\hline & & $\mathrm{Fe} / \mathrm{H}$ & 10 & $0.9940+(1.2657 \mathrm{E}-02)^{*} \mathrm{x}$ & 0.0032 & 0.028 & 0.99452 & 0.0073 & 0.937 & 0.887 & 0.973 & 0.014 \\
\hline & \multirow[t]{2}{*}{44} & $\begin{array}{l}\text { Fe/HM Ratio (ratio = 0) } \\
\text { Fe/HM Ratio (ratio > 0) }\end{array}$ & $\begin{array}{l}2 \\
8\end{array}$ & $\begin{array}{l}\text { Insufficient Data } \\
0.9988+(2.3311 \mathrm{E}\end{array}$ & 0.0033 & 0.070 & 0.95 & 0.0078 & 0.941 & 891 & & 0.017 \\
\hline & & Fe/HM Ratio (all) & 10 & $83+(3.0$ & 0.0030 & .166 & 0.95 & 0.0066 & 0.942 & .892 & 0.979 & 0.013 \\
\hline
\end{tabular}

Notes: ${ }^{1}$ Benchmark experiments for ${ }^{233} \mathrm{U}$ are described in Table 5-1; experiments for plutonium in Table 5-2; and, experiments for ${ }^{235} \mathrm{U}$ in Table 5-3.

${ }^{2} \mathrm{r}^{2}$ is the coefficient of determination used to compare estimated and actual values. Since the regression curve is linear (i.e., a straight line), a value of 1.0, the largest possible, means that calculated points lie in a straight line. A value less than 1.0 means calculated points do not lie in a straight line, and the smaller the value the less the correlation.

${ }^{3}$ All isotopes refers to all ${ }^{233} \mathrm{U},{ }^{235} \mathrm{U}$, and plutonium systems combined. 
HNF-3950 Rev. 0

\subsection{CONCLUSIONS}

The range of applicability for XSDRNPM calculations is defined by: (1) uranium of any ${ }^{235} \mathrm{U}$ enrichment; (2) plutonium containing up to $20 \mathrm{wt} \%{ }^{240} \mathrm{Pu}$; (3) iron in any proportion; (4) an AEF between 0.029 and $0.344 \mathrm{eV}$; and (5) geometric configurations for which neutron leakage is negligible. When $\mathrm{H} / \mathrm{X}$ falls between 125 and 3694 , the AEF is assured of falling between 0.029 and $0.344 \mathrm{eV}$. When moderators are present in addition to water, $\mathrm{H} / \mathrm{X}$ can be less than 125 while remaining within the applicable AEF range. Neutron leakage is negligible when the smallest dimension is large enough for $\mathrm{k}_{\text {eff }}$ to be indistinguishable from $\mathrm{k}_{\infty}$

An administrative margin of 0.10 will compensate for the extrapolations from the iron content in the benchmark experiments to the much higher iron content in K Basin sludge. An USL of 0.881 is acceptable for XSDRNPM calculations with 27-group cross sections, and an USL of 0.882 is acceptable with 44-group cross sections 
HNF-3950 Rev. 0

This page intentionally left blank. 


\subsection{REFERENCES}

ANSI/ANS, 1983, Nuclear Criticality Safety in Operations with Fissionable Materials Outside Reactors, ANSI/ANS-8.1, American National Standards Institute, New York, New York.

ANSI/ANS, 1994, Criticality Safety Criteria for the Handling, Storage, and Transportation of LWR Fuel Outside Reactors, ANSI Standard 8.17, American National Standards Institute, New York, New York.

Bowman, S. M., M. B. Emmett, and W. C. Jordan, 1998, "SCALE Criticality Safety Verification and Validation Package", ANS Transactions, Volume 78, June 1998, p. $160-161$.

Bowden D. C. and F. A. Graybill, 1966, "Confidence Bands of Uniform and Proportional Width for Linear Models, " American Statistics Association Journal, Volume 61, p. 182, March 1966.

Cain, V. R., 1995, A Computer Code to Perform Analyses of Criticality Validation Results, Y/DD-574, Martin Marietta Energy Systems, Inc., Oak Ridge Y-12 Plant, September 1995.

Carter, R. D., G . Kiel, and K. R. Ridgway, 1969, Criticality Handbook, ARH-600, Vol. II, Atlantic Richfield Hanford Company, Richland, Washington.

DeHart, M. D., and S. M. Bowman, 1994, Validation of the SCALE Broad Structure 44-Group ENDF-B/V Cross Section Library for Use in Criticality Safety Analyses, ORNL/TM-12460 (NUREG/CR-6102), Martin Marietta Energy Systems, Inc., Oak Ridge National Laboratory, September, 1994.

DOE, 1993, Guidelines for Preparing Criticality Safety Evaluations at DOE Non-reactor Nuclear Facilities, DOE-STD-3007-93, U. S. Department of Energy, Office of Nuclear Energy, Science, and Technology, Washington, D. C., November 1993.

Dyer, H. R., W. C. Jordan, and V. R. Cain 1991, "A Technique for Code Validation for Criticality Safety Calculations," ANS Transactions, Volume 63, p. 238, June 1991.

Easter, M. E., 1985, Validation of KENO V.a and Two Cross-Section Libraries for Criticality Calculations of Low-Enriched Uranium Systems, ORNL/CSD/TM-223, Martin Marietta Energy Systems, Inc., Oak Ridge National Laboratory, July 1985. 
Emmett, M. B., and W. C. Jordan, 1996, Guide to Verification and Validation of the SCALE-4 Criticality Safety Software, NUREG/CR-6483 (ORNL/TM-12834), Lockheed Martin Energy Research Corp., Oak Ridge National Laboratory, Oak Ridge, Tennessee.

FDH, 1997a, Criticality Safety Control of Fissionable Material, HNF-PRO-537, Fluor Daniel Hanford, Inc., Richland, Washington.

FDH, 1997b, Criticality Safety Evaluations, HNF-PRO-539, Fluor Daniel Hanford, Inc., Richland, Washington.

Greene, N. M., L. M. Petrie, N.E. Ford III, and J. W. Arwood, 1992, AMPX-77: A Modular Code System for Generating Coupled Multigroup Neutron Gamma Cross-Section Libraries from $E N D F / B-I V$ and/or ENDF/B-V, ORNL/CSD/TM-283, Martin Marietta Energy Systems, Inc., Oak Ridge National Laboratory, October 1992.

Greene, N. M., 1995, BONAMI: "Resonance Self-Shielding by the Bondarenko Method," Section FI of SCALE, A Modular Code System for Performing Standardized Computer Analyses for Licensing Evaluation, NUREG/CR-0200, Rev. 4

(ORNL/NUREG/CSD-2/R4), Vols. I-III , April 1995.

Greene, N. M., L. M. Petrie, and R. M. Westfall, 1995, "NITAWL-II: SCALE System Module for Performing Resonance Shielding and Working Library Production," Section F2 of SCALE, A Modular Code System for Performing Standardized Computer Analyses for Licensing Evaluation, NUREG/CR-0200, Rev. 4(ORNL/CSD-2/ R4), Vols. I-III, April 1995.

Greene, N. M., and L. M. Petrie, 1995, "XSDRNPM: A One-Dimensional Discrete-Ordinates Code for Transport Analysis," Section F3 of SCALE, A Modular Code System for Performing Standardized Computer Analyses for Licensing Evaluation, NUREG/CR-0200, Rev. 4 (ORNL/NUREG/CSD-2/R4), Vol. 1, II, Ill, April 1995.

Johnson, N. L., 1968, Ed., “Query,” Technometrics, Volume 10, pp. 207-209, February 1968.

Jordan, W.C., N. F. Landers, and L. M. Petrie, 1986, Validation of KENO V.a Comparison with Critical Experiments, ORNL/CSD/TM-238, Martin Marietta Energy Systems, Inc., Oak Ridge National Laboratory, December 1986.

Lichtenwalter, J. J., S. M. Bowman, M. D. DeHart, and C. M. Hopper, 1997, Criticality Benchmark Guide for Light-Water-Reactor Fuel in Transportation and Storage Packages, NUREG/CR-6361 (ORNL/TM-13211),), Lockheed Martin Energy Research Corp., Oak Ridge National Laboratory, Oak Ridge, Tennessee. 
ORNL, 1995a, SCALE, A Modular Code System for Performing Standardized Computer Analyses for Licensing Evaluation, NUREG/CR-0200, Rev. 4 (ORNL/NUREG/CSD-2/R4), Vols. I-III (April 1995). Available from Radiation Shielding Information Center at Oak Ridge National Laboratory as CCC-545.

ORNL, 1995b, SCALE Baseline Revision Report, BRR 94-003, May 2, 1995.

Paxton, H. C., and N. L. Pruvost, 1987, Critical Dimensions of Systems Containing ${ }^{235} \mathrm{U},{ }^{239} \mathrm{Pu}$, and ${ }^{233} U$, LA-10860-MS, Los Alamos National Laboratory, Los Alamos, New Mexico.

Petrie L. M., and N. F. Landers, 1995, "KENO V.a: An Improved Monte Carlo Criticality Program with Supergrouping," Section Fll of SCALE, A Modular Code System for Performing Standardized Computer Analyses for Licensing Evaluation, NUREG/CR-0200, Rev. 4 (ORNL/NUREG/CSD-2/R4), Vols. I-III, April 1995. Available from Radiation Shielding Information Center at Oak Ridge National Laboratory as CCC-545.

Primm, R. T., III, 1993, Criticality Safety Studies of Building 3019 Cell 4 and In-Line Storage Wells, ORNL/TM-12374, Martin Marietta Energy Systems, Inc., Oak Ridge National Laboratory, November 1993.

Richey, C. R., 1968, "Theoretical Analysis of Homogeneous Plutonium Critical Experiments", Nuclear Science and Engineering, January 1968. 
HNF-3950 Rev. 0

This page intentionally left blank. 
HNF-3950 Rev. 0

APPENDIX A

SAMPLE STATISTICAL CALCULATION

A-1 
HNF-3950 Rev. 0

This page intentionally left blank. 
HNF-3950 Rev. 0

APPENDIX A

\section{SAMPLE STATISTICAL CALCULATION}

usistats: a utility to calculate upper subcritical

limits for criticality safety applications

Version 1.3.6, December 15, 1998

Oak Ridge National Laboratory

Input to statistical treatment from file:c $7 z 1 . \mathrm{i}$

Title: XSDRN Validation Cases with $\mathrm{H} / \mathrm{X}$ vs Enrichment $(\mathrm{H} / \mathrm{X}>100)$

$\begin{array}{ll}\text { Proportion of the population }= & .995 \\ \text { Confidence of fit }= & 950 \\ \text { Confidence on proportion }= & 950 \\ \text { Number of observations } \Rightarrow & 17 \\ \text { Minimum value of closed band }= & 0.00 \\ \text { Maximum value of closed band }= & 0.00 \\ \text { Administrative margin }= & 0.10\end{array}$

independent dependent

variable $-\mathrm{x}$ variable $-\mathrm{y}$

$\begin{array}{ll}4.05000 \mathrm{E}+02 & 1.01400 \mathrm{E}+00 \\ 6.58000 \mathrm{E}+02 & 1.02686 \mathrm{E}+00 \\ 3.69400 \mathrm{E}+03 & 1.00487 \mathrm{E}+00 \\ 1.15400 \mathrm{E}+03 & 1.00059 \mathrm{E}+00 \\ 1.06700 \mathrm{E}+03 & 1.01845 \mathrm{E}+00 \\ 1.03100 \mathrm{E}+03 & 1.01653 \mathrm{E}+00 \\ 9.80000 \mathrm{E}+02 & 1.01722 \mathrm{E}+00 \\ 7.58000 \mathrm{E}+02 & 1.01751 \mathrm{E}+00 \\ 4.22000 \mathrm{E}+02 & 1.01712 \mathrm{E}+00 \\ 1.25000 \mathrm{E}+02 & 1.01567 \mathrm{E}+00 \\ 1.25000 \mathrm{E}+02 & 1.01657 \mathrm{E}+00 \\ 6.23000 \mathrm{E}+02 & 1.00435 \mathrm{E}+00 \\ 1.83500 \mathrm{E}+03 & 9.95920 \mathrm{E}-01 \\ 1.37800 \mathrm{E}+03 & 9.98320 \mathrm{E}-01 \\ 1.17700 \mathrm{E}+03 & 9.97880 \mathrm{E}-01 \\ 1.03300 \mathrm{E}+03 & 9.94920 \mathrm{E}-01 \\ 9.72000 \mathrm{E}+02 & 9.96440 \mathrm{E}-01\end{array}$

WARNING $* * *$ the test for normal may be unreliable because of insufficient data.

chi $=8.5882$ (upper bound $=9.49)$. The data tests normal.

Output from statistical trcatment

XSDRN Validation Cases with $\mathrm{H} / \mathrm{X}$ vs Enrichment $(\mathrm{H} / \mathrm{X} / \mathrm{X}>100)$

Number of data points $(\mathfrak{n}) \quad 17$

Linear regression, $k(x)$

Confidence on fit (1-gamma) [input]

$1.0143+(-5.1756 \mathrm{E}-06)^{*} \mathrm{X}$

Confidence on proportion (alpha) [input] $\quad 95.0 \%$ 


\section{HNF-3950 Rev. 0}

Proportion of population falling above lower tolerance interval (rho) [input] Minimum value of $X$

$99.5 \%$

Maximum value of $X$

Average value of

Average value of $k$ 3694.0000

Minimum value of $k$

1025.7059

Variance of fit, $s(\mathrm{k}, \mathrm{X})^{\wedge} 2$

1.00901

Within variance, $s(w)^{\wedge} 2$

0.99492

Pooled variance, $s(p)^{\wedge} 2$

9.2377E-05

Pooled std. deviation, $s(p)$

$0.0000 \mathrm{E}+00$

9.2377E-05

$9.6113 \mathrm{E}-03$

$\mathrm{C}\left(\right.$ alpha,rho) ${ }^{*} \mathrm{~s}(\mathrm{p})$

$5.5789 \mathrm{E}-02$

student-t@ (n-2,1-gamma)

1. $75300 \mathrm{E}+00$

Confidence band width, $W$

2.2129E-02

Minimum margin of subcriticality, $C^{*} \mathrm{~s}(\mathrm{p})-\mathrm{W} \quad 3.3659 \mathrm{E}-02$

Upper subcritical limits: $(125.00 \quad<=X<=3694.0)$

$* * * * * * * * * * * * * * * * * * * * * * *$

USL Method 1 (Confidence Band with

Administrative Margin) $\quad$ USL1 $=0.8922+(-5.1756 \mathrm{E}-06) * X(X>2767.1)$

$$
=0.8779 \quad(\mathrm{X}<=* * * * * *)
$$

USL Method 2 (Single-Sided Uniform

Width Closed Interval Approach $) \quad$ USL2 $=0.9585+(-5.1756 \mathrm{E}-06) * \mathrm{X}(\mathrm{X}>2767.1)$

$$
=0.9442 \quad(\mathrm{X}<=* * * * * * *)
$$

USLs Evaluated Over Range of Parameter X:

$* * * * * * * * * * * * * * * * * * * * * * * * * * * * * * * * * * *$

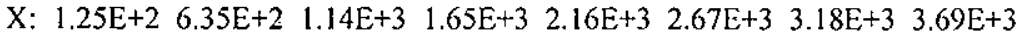

$\begin{array}{llllllllll}\text { USL-1: } & 0.8779 & 0.8779 & 0.8779 & 0.8779 & 0.8779 & 0.8779 & 0.8757 & 0.8731\end{array}$

$\begin{array}{lllllllll}\text { USL-2: } & 0.9442 & 0.9442 & 0.9442 & 0.9442 & 0.9442 & 0.9442 & 0.9421 & 0.9394\end{array}$

Thus spake USLSTATS

Finis. 
HNF-3950 Rev. 0

APPENDIX B

BENCHMARK EXPERIMENTS DESCRIBED IN NUREG/CR-6483

B-1 
HNF-3950 Rev. 0

This page intentionally left blank.

B-2 


\section{APPENDIX B \\ BENCHMARK EXPERIMENTS DESCRIBED IN NUREG/CR-6483}

This appendix describes validation problems from NUREG/CR-6483 (Emmett and Jordan 1996) used in this report. XSDRNPM cases were run in one of two different modes: (1) using the CSAS1X control module or (2) using the CSASN control module to generate cross sections for the XSDRNPM standalone code. The CSASIX module calls BONAMI-S, NITAWL-S, and XSDRNPM-S. CSASIX and CSASN create resonance-corrected, cell-weighted, microscopic libraries in the AMPX working library format. Data is input into CSAS1X in the following format:

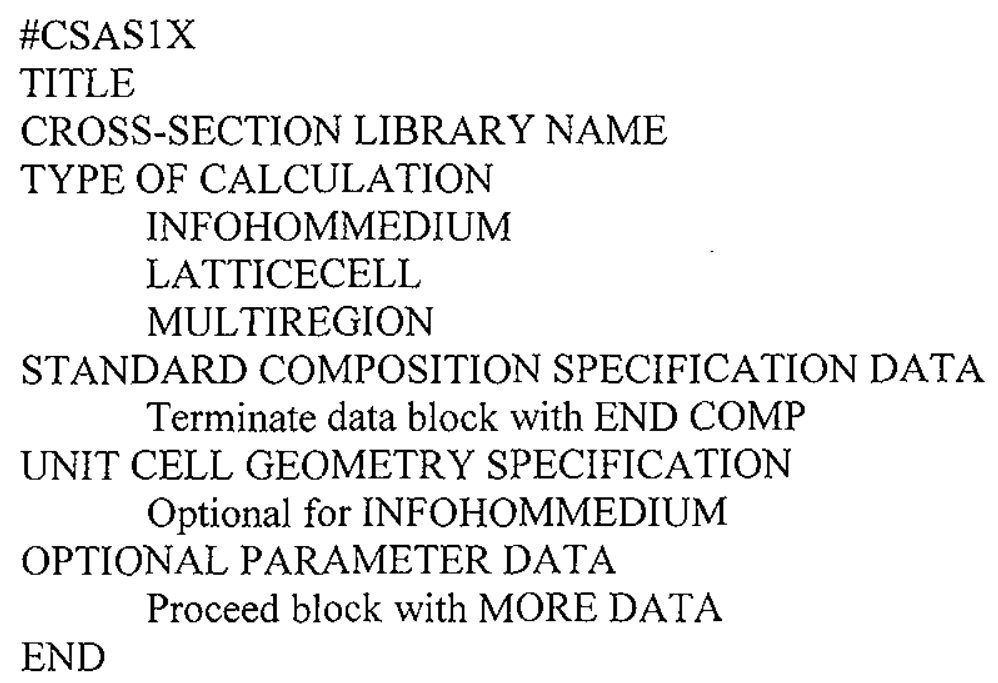

\section{B1.0 INPUT LISTINGS}

A summary description and a listing of the code input are provided for one representative case from each group of similar experiments. Input listing for all cases can be downloaded from the SCALE website. The home address of the SCALE website is:

http://www.cad.ornl.gov/cad-nea/text/scale-home.html

Case 111-xx

References: NUREG/CR-6483 (Emmett and Jordan 1996)/Table 29

TM12374 (Primm 1993)/Appendix C

Specific Cases: Case 111_20 Case 111_25

Description for Case 111_20:

${ }^{233} \mathrm{U}$ at a concentration of $1.52924 \mathrm{E}-04 \mathrm{at} / \mathrm{b}-\mathrm{cm}(62.00 \mathrm{~g} / \mathrm{L})$ in a $26.4-\mathrm{cm}(10.39-\mathrm{in}$.)

diameter sphere of ${ }^{233} \mathrm{U}$ nitrate -water solution. Solution is in $0.1-\mathrm{cm}$ thick aluminum shell surrounded by $20-\mathrm{cm}(7.87-\mathrm{in}$.) thick, close-fitting water reflector.

Input Listing for Case 111-20

\#csas 1x

expt. 111-20 


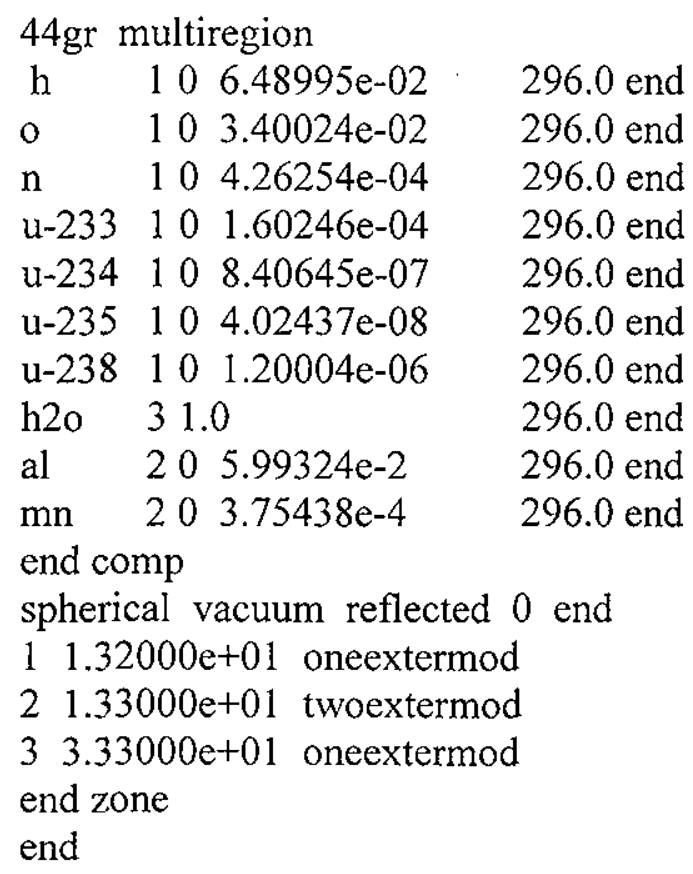

Case 1727-xx

References: NUREG/CR-6483 (Emmett and Jordan 1996)/Table 29

TM12374 (Primm 1993)/Appendix C

Specific Cases: Case 1727_01 Case 1727_02 Case 1727_03

Case 1727_04 Case 172705 Case 1727_06

Case 1727_07 Case 1727_08 Case 1727_14

Description for Case 1727_01:

Case 1727_15

$11.9679-\mathrm{cm}\left(4.71-\mathrm{in}\right.$.) diameter, bare, metal, ${ }^{233} \mathrm{U}$ sphere.

Input Listing for Case 1727_01

\#csas $1 \mathrm{x}$

la-3067-msr table iv, entry 1, bare, metal, $\mathrm{u}-233$ sphere

$44 \mathrm{gr}$

multiregion

u-233 $10.04 .67087 \mathrm{e}-2 \quad 300.0$ end

u-234 $10.05 .92563 \mathrm{e}-4 \quad 300.0$ end

u-235 $10.01 .27660 \mathrm{e}-6 \quad 300.0$ end

u-238 $10.02 .84311 \mathrm{e}-4 \quad 300.0$ end

end comp

spherical vacuum reflected 0.0 end

15.98393 noextermod

end zone

end

Case 1727-xx

References: NUREG/CR-6483 (Emmett and Jordan 1996)/Table 31

TM12374 (Primm 1993)/Appendix E 


\section{HNF-3950 Rev. 0}

Specific Cases: $\quad$ Case 1727_09 Case 1727_10

Description of Case 1727_09:

$8.2434-\mathrm{cm}(3.245 \overline{4}-\mathrm{in}$.) diameter plutonium sphere in $0.0127-\mathrm{cm}(0.0050$-in.) thick nickel shell with $30.480-\mathrm{cm}(12.000$-in.) thick close-fitting water reflector. Plutonium contains $5.20 \mathrm{wt} \%{ }^{240} \mathrm{Pu}$.

Input Listing for Case 1727_09

\#csas $1 \mathrm{x}$

la-3067-msr table iiia1, entry 13, water ref., metal, pu sphere

$44 \mathrm{gr}$

multiregion

pu-239 $10.04 .6994 \mathrm{e}-2300.0$ end

pu-240 $10.02 .5757 \mathrm{e}-3300.0$ end

pu-241 $10.01 .4798 \mathrm{e}-4300.0$ end

pu-242 $10.09 .8245 \mathrm{e}-6300.0$ end

ni $\quad 21.0300 .0$ end

h2o $\quad 31.0300 .0$ end

end comp

spherical vacuum reflected 0.0 end

14.1217 oneextermod

24.1344 twoextermod

334.614 noextermod

end zone

end

\section{Case 2109-xx}

References: NUREG/CR-6483 (Emmett and Jordan 1996)/Table 31

TM12374 (Primm 1993)/Appendix E

Specific Cases: Case 2109_25

Description of Case 2109_25:

9.06454-cm (3.56 $\overline{8} 7$-in.) diameter plutonium metal sphere with a $19.52988-\mathrm{cm}$

(7.7200-in.) natural uranium reflector. Plutonium contains $4.81 \mathrm{wt} \%{ }^{240} \mathrm{Pu}$.

Input Listing for Case 2109_25:

\#csas $1 \mathrm{x}$ parm $=(\operatorname{size}=300000)$

pu benchmark 25 from 2109 , pu metal sphere reflected with nat. u

$44 \mathrm{gr}$

multiregion

pu-239 $10.03 .713 \mathrm{e}-2 \quad 300.0$ end

pu-240 $10.01 .870 \mathrm{e}-3 \quad 300.0$ end

pu-241 $10.01 .164 \mathrm{e}-4 \quad 300.0$ end

$\mathrm{u}-235 \quad 20.03 .456 \mathrm{e}-4 \quad 300.0$ end

$\mathrm{u}-238 \quad 20.04 .772 \mathrm{e}-2 \quad 300.0$ end

end comp

spherical vacuum reflected 0.0 end

14.53227 oneextermod

224.1411 noextermod

end zone

end 


\section{HNF-3950 Rev. 0}

Case 2110-xx

References: NUREG/CR-6483 (Emmett and Jordan 1996)/Table 31

TM12374 (Primm 1993)/Appendix E

Specific Cases:

Case 2110_01

Case 2110_02

Case 2110_07

Case 2110_03

Case 2110_04

Case 2110_32

Case 2110_30

Description of Case 2110_01:

Infinite volume of homogeneous ${ }^{239} \mathrm{Pu}$-water solution.

Input Listing for Case 2110_01:

\#csas1x

benchmark\#1 infinite homog. critical solution of $239 \mathrm{Pu}$ in water

44gr infhommedium

pu-239 $101.8113 \mathrm{e}-5$ end

o $\quad 103.3459 \mathrm{e}-2$ end

h $\quad 106.6918 \mathrm{e}-2$ end

end comp

end

\section{Case BAPLX}

References: NUREG/CR-6483 (Emmett and Jordan 1996)/Table 32

TM12460 (Primm 1993)

Specific Cases: $\quad$ Case BAPL1

Case BAPL2

Case BAPL1-1

Case BAPL3

Case BAPL2-1

Case BAPL3-1

Description of Case BAPL1:

Triangular lattice of aluminum clad $\mathrm{UO}_{2}$ rods in water. Enrichment is $1.31 \mathrm{wt} \%{ }^{235} \mathrm{U}$.

Input Listing for BAPL1:

$=$ csasn

bapl-1 lattice cell calc. $44 \mathrm{gr}$ - mdd 5-06-93

$44 \mathrm{gr}$ latt

$\mathrm{u}-235 \quad 103.112-4$ end

$\mathrm{u}-238 \quad 102.3127-2$ end

o $\quad 104.6946-2$ end

al $206.025-2$ end

h $306.676-2$ end

o $\quad 303.338-2$ end

end comp

triangpitch $1.5578 \quad 0.9728 \quad 1 \quad 3 \quad 1.150621 .00840$ end

end

=xsdrnpm

bapl-1 lattice, 44gr - mdd - 4-06-93

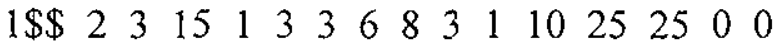

$2 \$ \$ \begin{array}{llllll} & -2 & 0 & -1 & \mathrm{e}\end{array}$

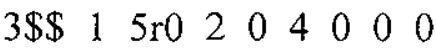

$4 \$ \$-144 \quad 1 \quad-2$ e

$5^{* *}$ a6 0.055 .0310 e t

$13 \$ \$ 2 \mathrm{r} 32 \mathrm{rr} 1$ 


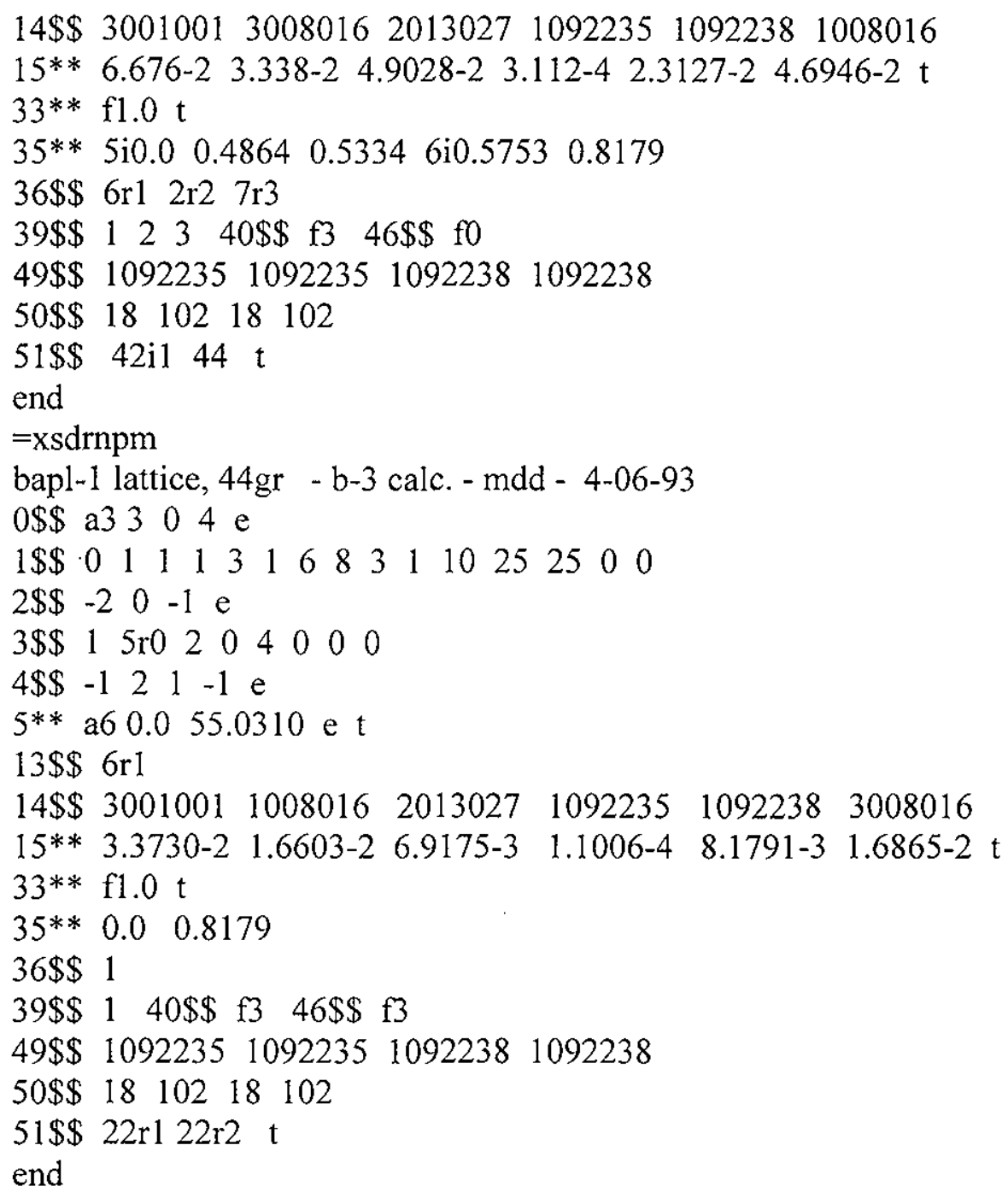

Case BIG10

References: NUREG/CR-6483 (Emmett and Jordan 1996)/Table 32

TM12460 (DeHart and Bowman 1994)

Description of Case BIG10:

60.96-cm (24.00-in.) diameter uranium metal sphere with $15.24-\mathrm{cm}(6.00$-in) thick depleted uranium reflector. ${ }^{235} \mathrm{U}$ enrichment is $10.07 \mathrm{wt} \%$.

Input Listing for Case BIG10:

\begin{tabular}{|c|c|c|}
\hline $\begin{array}{l}\text { big- } 10 \mathrm{k}- \\
44 \text { gr mul }\end{array}$ & $\begin{array}{l}\text {-calculation -- } \\
\text { iltiregion }\end{array}$ & 44 gr mdd - 5-06-93 \\
\hline$u-233 \quad 1$ & $\begin{array}{lll}1 & 0.0 & 1.0-15\end{array}$ & end \\
\hline np-237 1 & $\begin{array}{llll}1 & 0.0 & 1.0-15\end{array}$ & end \\
\hline pu-239 1 & $\begin{array}{lll}1 & 0.0 & 1.0-15\end{array}$ & end \\
\hline$u-234$ & $10.05 .00-5$ & end \\
\hline$u-235$ & $10.04 .84-3$ & end \\
\hline u-238 & $\begin{array}{llll}1 & 0.0 & 4.268-2\end{array}$ & end \\
\hline$u-235 \quad 2$ & $\begin{array}{lll}2 & 0.0 & 1.00-4\end{array}$ & end \\
\hline$u-238 \quad 2$ & $\begin{array}{llll}2 & 0.0 & 4.797-2\end{array}$ & end \\
\hline
\end{tabular}


HNF-3950 Rev, 0

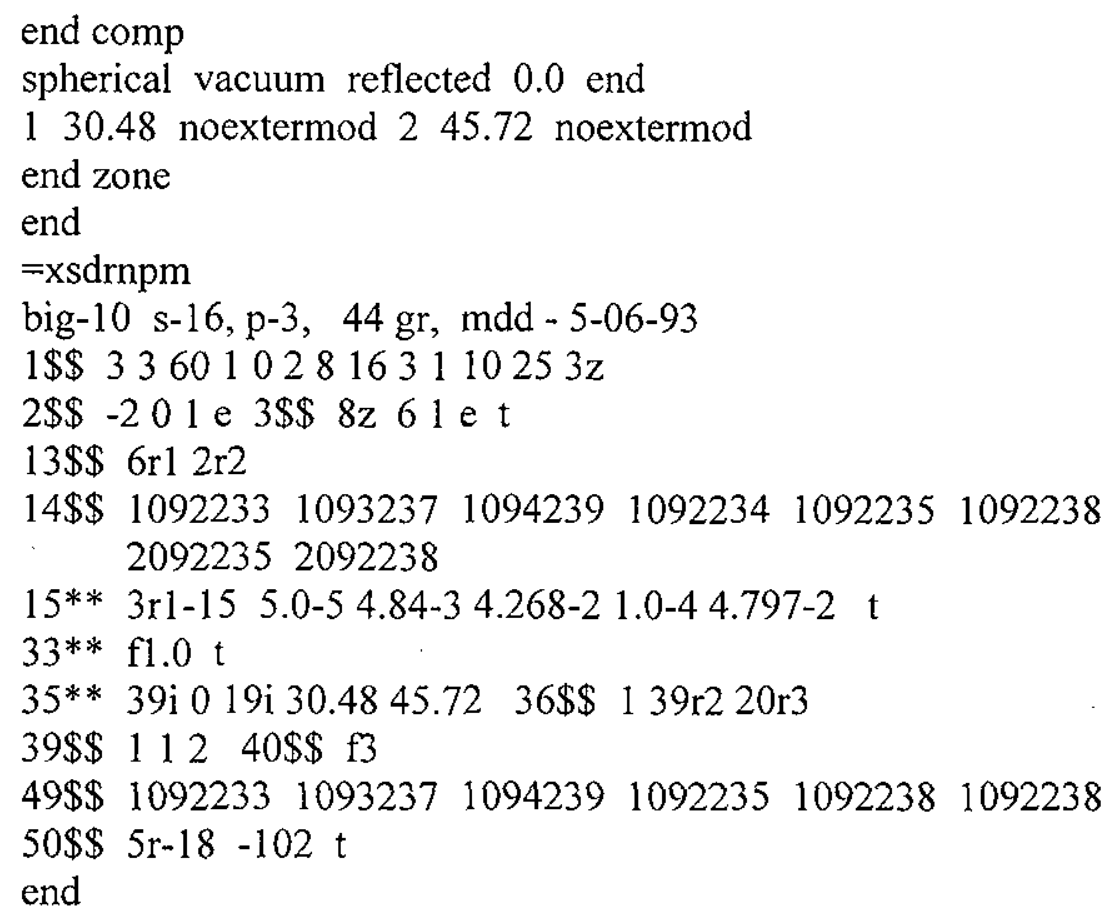

\section{Case FLAT25}

References: NUREG/CR-6483 (Emmett and Jordan 1996)/Table 32

TM12460 (DeHart and Bowman 1994)

Description of Case FLAT25:

12.232-cm (4.816-in.) diameter highly enriched $\left(94.2 \mathrm{wt} \%{ }^{235} \mathrm{U}\right)$ uranium metal sphere with $18.014-\mathrm{cm}\left(7.092\right.$-in) thick natural uranium $\left(0.698 \mathrm{wt} \%{ }^{235} \mathrm{U}\right)$ reflector.

Inpurt Listing for FLAT25:

$=$ csasn

flattop-25 k-calculation -- 44 gr structure mdd - 5-06-93

$44 \mathrm{gr}$ multiregion

$\mathrm{u}-233 \quad 1 \quad 0.0 \quad 1.0-15$ end

$\begin{array}{lllll}\mathrm{np}-237 & 1 & 0.0 & 1.0-15 & \text { end }\end{array}$

$\begin{array}{lllll}\text { pu-239 } & 1 & 0.0 & 1.0-15 & \text { end }\end{array}$

$\mathrm{u}-234 \quad 1 \quad 0.0 \quad 4.90-4$ end

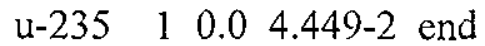

$\begin{array}{lllll}\mathrm{u}-238 & 1 & 0.0 & 2.70-3 & \text { end }\end{array}$

$\mathrm{u}-235 \quad 2 \quad 0.0 \quad 3.40-4$ end

$\begin{array}{lllll}\mathrm{u}-238 & 2 & 0.0 & 4.774-2 & \text { end }\end{array}$

end comp

spherical vacuum reflected 0.0 end

16.116 noextermod 224.13 noextermod

end zone

moredata collapse end

end

$1 \$ \$ 33601028163110253 z$

$2 \$ \$-200$ e $3 \$ \$ 8 z 51$ e t

$13 \$ \$ 6 r 12 \mathrm{r} 2$ 
HNF-3950 Rev. 0

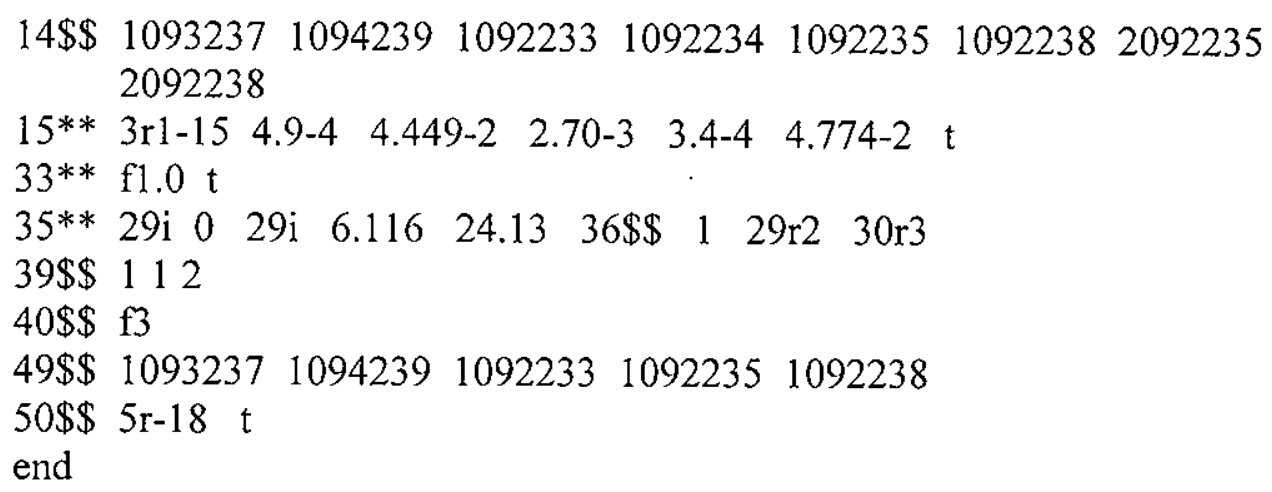

Case GODIVA

References: NUREG/CR-6483 (Emmett and Jordan 1996)/Table 32

TM12460 (DeHart and Bowman 1994)

Description of GODIVA:

17.482-cm (6.883-in.) diameter, bare, highly enriched $\left(94.7 \mathrm{wt} \%{ }^{235} \mathrm{U}\right)$ uranium metal sphere.

Input Listing for GODIVA:

$=$ csasn $\quad$ parm $={ }^{\prime}$ 'size $=300000^{\prime}$

godiva k-calculation -- 44gr mdd - 5-06-93

44gr multiregion

np-237 $10.0 \quad 1.0-15$ end

pu-239 $110.0 \quad 1.0-15$ end

$\begin{array}{lllll}\mathrm{u}-233 & 1 & 0.0 & 1.0-15 & \text { end }\end{array}$

$\mathrm{u}-234 \quad 1 \quad 0.0 \quad 4.92-4$ end

$\begin{array}{lllll}u-235 & 1 & 0.0 & 4.50-2 & \text { end }\end{array}$

$\begin{array}{llll}u-238 & 1 & 0.0 & 2.498-3 \\ & \text { end }\end{array}$

end comp

spherical vacuum reflected 0.0 end

18.741 noextermod

end zone

moredata collapse end

end

$=$ xsdrnpm

godiva s-16, p-3, 44gr mdd - 5-06-93

$1 \$ \$ 32401016163110253 z$

$2 \$ \$-100$ e $3 \$ \$ 8 z 51 \mathrm{e} \mathrm{t}$

$13 \$ \$$ f1

$14 \$ \$ 1093237 \quad 109423910922331092234 \quad 1092235 \quad 1092238$

$15 * * 3 r 1-15 \quad 4.92-4 \quad 4.5-2 \quad 2.498-3 \quad \mathrm{t}$

$33 * *$ f1.0 t

$35 * * 39 \mathrm{i} 08.741 \quad 36 \$ \$ 139 \mathrm{r} 2$

$39 \$ \$ 11 \quad 40 \$ \$$ f3

49\$\$ $1093237 \quad 109423910922331092235 \quad 1092238$

$50 \$ \$ 5 \mathrm{r}-18 \mathrm{t}$

end 


\section{Case H2OX1}

References: NUREG/CR-6483 (Emmett and Jordan 1996)/Table 32

Description of H20X1:

TM12460 (DeHart and Bowman 1994)

$13.718-\mathrm{cm}(5.400-\mathrm{in}$.$) highly enriched \left(94.8 \mathrm{wt} \%{ }^{235} \mathrm{U}\right)$ uranium metal sphere with a $20.14-\mathrm{cm}(7.930$-in.) thick water reflector.

Input Listing for Case $\mathrm{H} 2 \mathrm{OX} 1$ :

$=$ csasn

h2ox-1 h2o-refl u-sphere: k-calc - 44 gr , mdd - 5-06-93

44gr multiregion

\begin{tabular}{|c|c|c|}
\hline & 10.0 & $1.0-20$ \\
\hline$d-234$ & 10.0 & $4.761-4$ \\
\hline$u-235$ & 10.0 & $4.4515-2$ \\
\hline 238 & 10.0 & $2.3872-3$ \\
\hline h & 200 & $6.692-2$ \\
\hline & 200 & $3.346-2$ \\
\hline
\end{tabular}

end comp

spherical vacuum reflected 0.0 end

16.859 oneextermad 227.0 noextermod

end zone

end

=xsdrnpm

k-calc\&react rates for h2ox-1 h20-refl 44gr up - mdd - 5-06-93

$1 \$ \$ 327010206163110403 z$

$2 \$ \$-25 z-13 z 3 \$ \$ 7 z 1121$ e t

$13 \$ \$ 4 \mathrm{r} 122$

$14 \$ \$ 109223310922341092235 \quad 109223820010012008016$

$15 * * 1-20 \quad 4.761-4 \quad 4.4515-2 \quad 2.3872-3 \quad 6.692-2 \quad 3.346-2$

$\mathrm{t}$

$33 \#$ f1.0t

$35^{* *}$

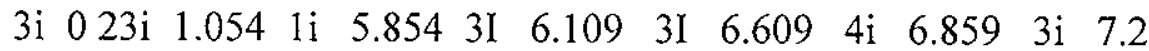

3I $7.7 \quad 8.7$ 17I $9.0 \quad 27.0$

$36 \$ 38 \mathrm{r} 1 \quad 32 \mathrm{r} 2 \quad 39 \$ \$ 12 \quad 40 \$ \$ \mathrm{f} 3$

$49 \$ \$ 3 r 1092233 \quad 3 r 1092234 \quad 3 r 1092235 \quad 3 r 1092238$

$50 \$ \$-101-102-18 \quad 3 q 3$

$38 * * \mathrm{z}$ f 1.0

$\mathrm{t}$

end

\section{Case HI240R}

References: NUREG/CR-6483 (Emmett and Jordan 1996)/Table 32

TM12460 (DeHart and Bowman 1994)

Description of HI24OR:

$66.80-\mathrm{cm}(26.30-\mathrm{in}$.$) diameter sphere of plutonium nitrate in a 0.08-\mathrm{cm}(0.03-\mathrm{in}$.) thick steel container with a $20.00-\mathrm{cm}\left(7.87\right.$-in.) thick, close-fitting, water reflector. ${ }^{240} \mathrm{Pu}$ content of $45 \mathrm{wt} \%$. 
HNF-3950 Rev. 0

Input Listing for Case HI240R:

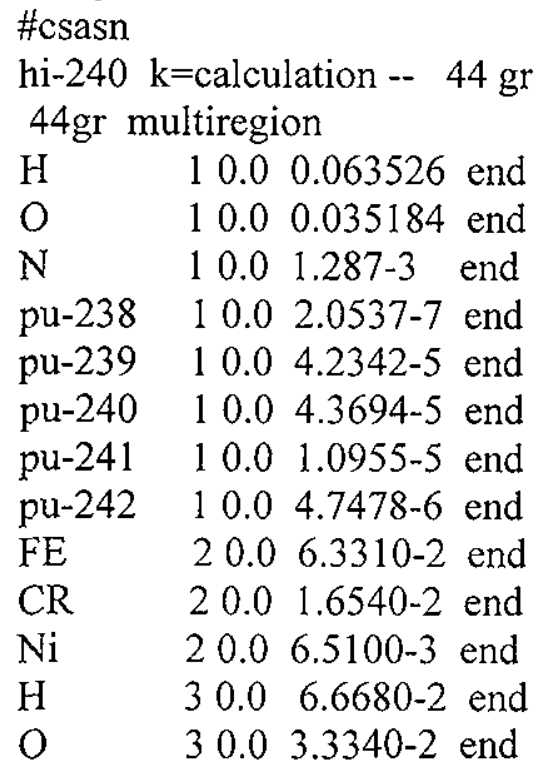

end comp

spherical vacuum reflected 0.0 end

133.400

233.480

353.480

end zone

end

\#xsdrnpm

hi-240 s-08/p-3, 44-grp, rqw 6-19-92

$-1 \$ \$ 300000 \mathrm{e}$

$1 \$ \$ 33721031383110453 z$

$2 \$ \$-15 z-1$ e $3 \$ \$ 8 z 51$ e $\mathrm{t}$

$13 \$ \$ 8 \mathrm{r} 13 \mathrm{r} 22 \mathrm{r} 3$

$14 \$ \$ 1001001 \quad 10080161007014 \quad 1094238 \quad 109423910942401094241$

109424220260002024000202800030010013008016

$\begin{array}{lllllll}15^{* *} & 6.3526-2 & 3.5184-2 & 1.2870-3 & 2.0537-7 & 4.2342-5 & 4.3694-5\end{array}$

$\begin{array}{llllllll}1.0955-5 & 4.7478-6 & 6.3310-2 & 1.6540-2 & 6.5100-3 & 6.6680-2 & 3.3340-2 & \mathrm{t}\end{array}$

$33 * *$ fl. 0 t

$\begin{array}{llllllll}35 * * & 49 \mathrm{i} & 0 & 33.400 & 33.440 & 19 \mathrm{i} & 33.480 & 53.480\end{array}$

$36 \$ \$ 50 \mathrm{r} 12 \mathrm{r} 2 \quad 20 \mathrm{r} 3$

$39 \$ \$ 12340 \$ \$$ f3

$49 \$ \$ 10942391094240109423910942401001001$

$50 \$ \$ 2 \mathrm{r}-18 \quad 3 \mathrm{r}-102 \mathrm{t}$

end

Case JEZBxx

References: NUREG/CR-6483 (Emmett and Jordan 1996)/Table 32

TM12460 (DeHart and Bowman 1994)

Specific Cases: Case JEZB23 Case JEZBEL JEZBPU 


\section{HNF-3950 Rev. 0}

Description of JEZBEL:

12.770-cm (5.028-in.) diameter, bare plutonium sphere.

Input Listing for Case JEZBEL:

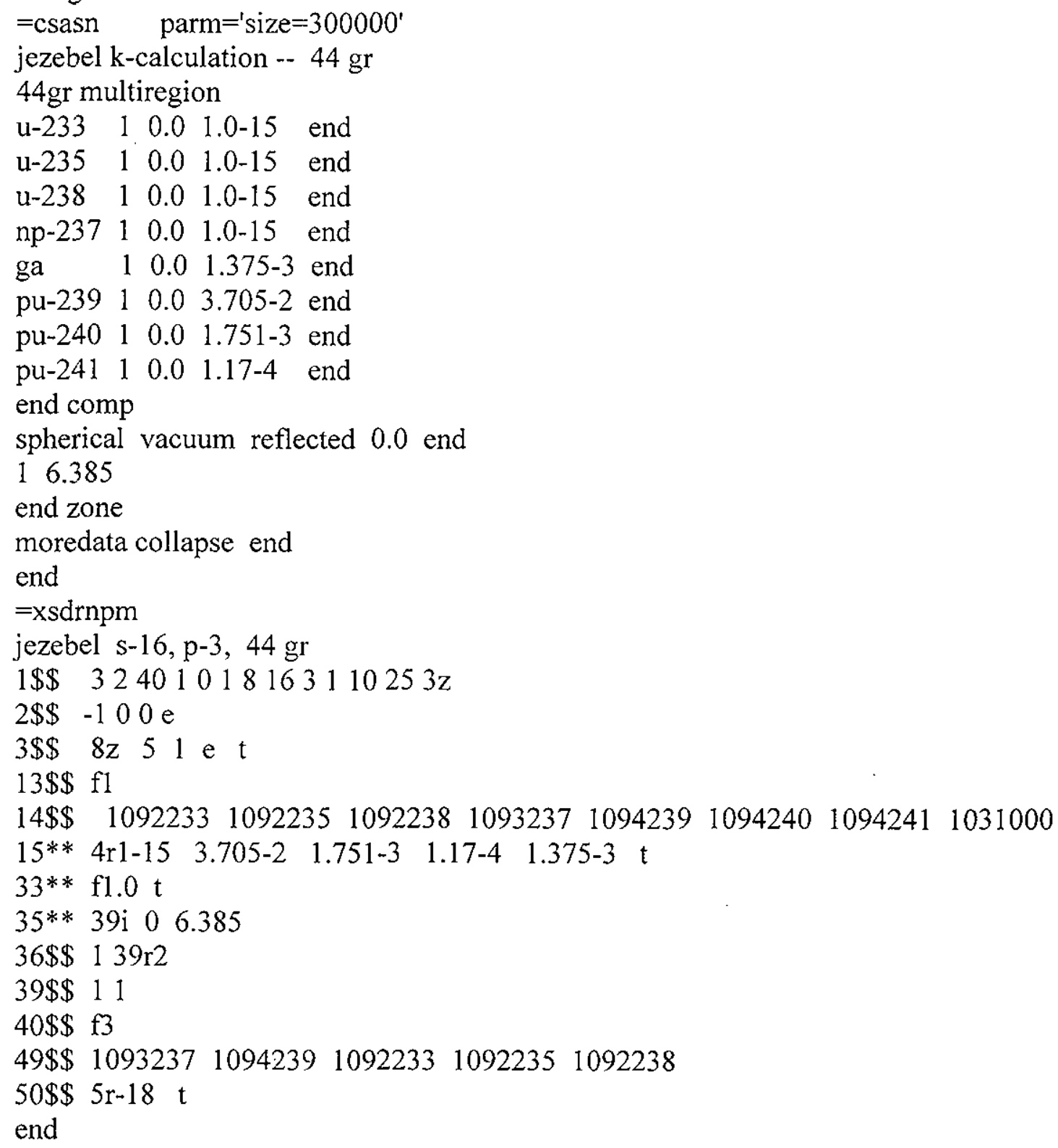

Case ORNLX

References: NUREG/CR-6483 (Emmett and Jordan 1996)/Table 32 TM12460 (DeHart and Bowman 1994)

Specific Cases: $\quad$ Case ORNL1 Case ORNL2 Case ORNL3

Case ORNL4 Case ORNL10

Description of ORNL1:

$94.4 \mathrm{wt} \%{ }^{235} \mathrm{U}$ enriched, 69.19-cm (27.24-in.) diameter, bare, sphere of ${ }^{235} \mathrm{U}$ nitride in . water. ${ }^{235} \mathrm{U}$ concentration is $18.7 \mathrm{~g} / \mathrm{L}$.

Input Listing for Case ORNL1:

\#csasn 


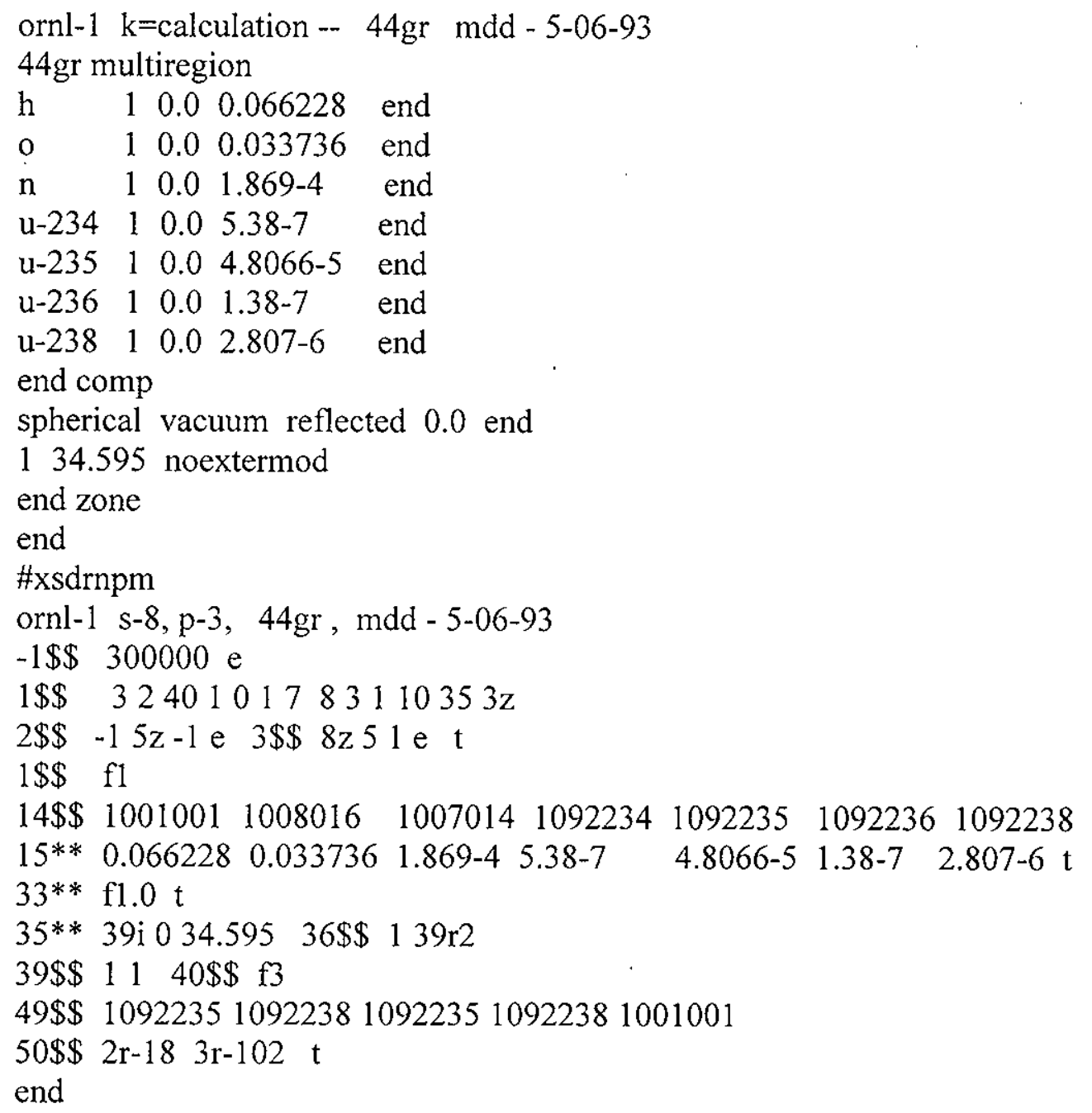

Case PNL3

References: NUREG/CR-6483 (Emmett and Jordan 1996)/Table 32 TM12460 (DeHart and Bowman 1994)

Specific Cases: Case PNL3 Case PNL6B

Description of PNL3:

45.40-cm-(17.87-in.) diameter, bare, sphere of plutonium, nitrogen, iron, and water.

Input Listing for Case PNL3:

\#csasn

pnl3fg $\mathrm{k}=$ calculation -- $44 \mathrm{gr}$ mdd - 5-06-93

44gr multiregion

h $\quad 1 \quad 0.0 \quad 0.064950$ end

$\begin{array}{lllll}0 & 1 & 0.0 & 0.034410 & \text { end }\end{array}$

$\mathrm{n} \quad \begin{array}{lllll}\mathrm{n} & 0.0 & 7.393-4 & \text { end }\end{array}$

fe $\quad \begin{array}{llll}1 & 0.0 & 1.294-6 & \text { end }\end{array}$

pu-239 $10.0 \quad 5.3950-5$ end

pu-240 $110.0 \quad 2.355-6$ end

end comp

spherical vacuum reflected 0.0 end 


\section{HNF-3950 Rev. 0}

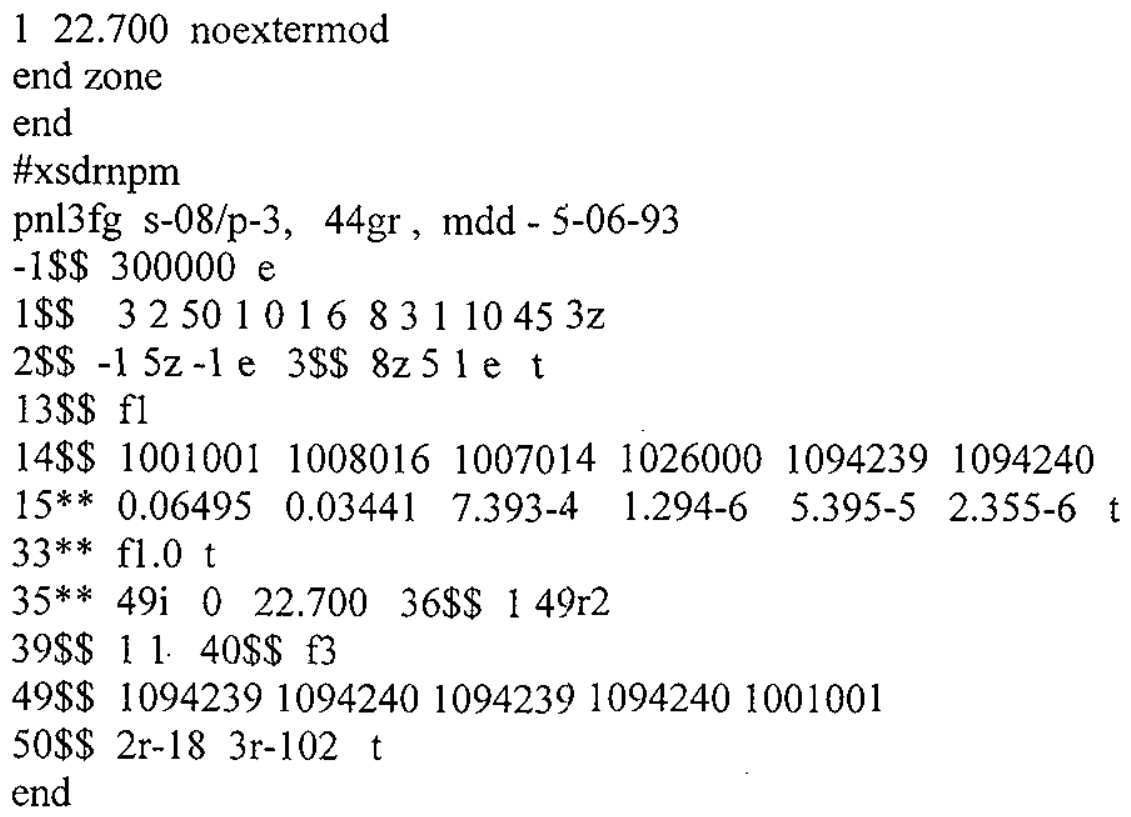

Case TRXX

References: NUREG/CR-6483 (Emmett and Jordan 1996)/Table 32 TM12460 (DeHart and Bowman 1994)

Specific Cases: $\quad$ Case TRX1 Case TRX1-1

Case TRX2 Case TRX2-1

Description of TRX1:

Triangular lattice of $1.29 \mathrm{wt} \%{ }^{235} \mathrm{U}$ enriched uranium fuel pins in water. Pins clad in aluminum. Cylindrical geometry.

Input Listing for CaseTRX1:

$=$ csasn

trx-1 lattice cell calculation -- $44 \mathrm{gr}$

44 gr latt

u-235 $106.253-4$ end

u-238 $104.7205-2$ end

al $\quad 2 \quad 06.025-2$ end

h $\quad 3 \quad 06.676-2$ end

o $\quad 3 \quad 03.338-2$ end

end comp

triangpitch $1.8060 \quad 0.983013 \quad 31.150621 .00840$ end end

$=x$ sdrnpm

trx-1 lattice, $-44 \mathrm{gr}$

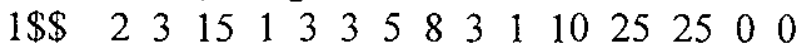

$2 \$ \$-2 \quad 0-1 \quad \mathrm{e}$

$3 \$ \$ 15 \mathrm{r} 020004000$

$4 \$ \$-144 \quad 1-2 \mathrm{e}$

$5^{* *} \quad$ a6 $0.041 .6114 \mathrm{e} \mathrm{t}$

$13 \$ \$ 2 \mathrm{r} 32 \mathrm{2} 2 \mathrm{r} 1$

$14 \$ \$ 30010013008016201302710922351092238$ 
HNF-3950 Rev. 0

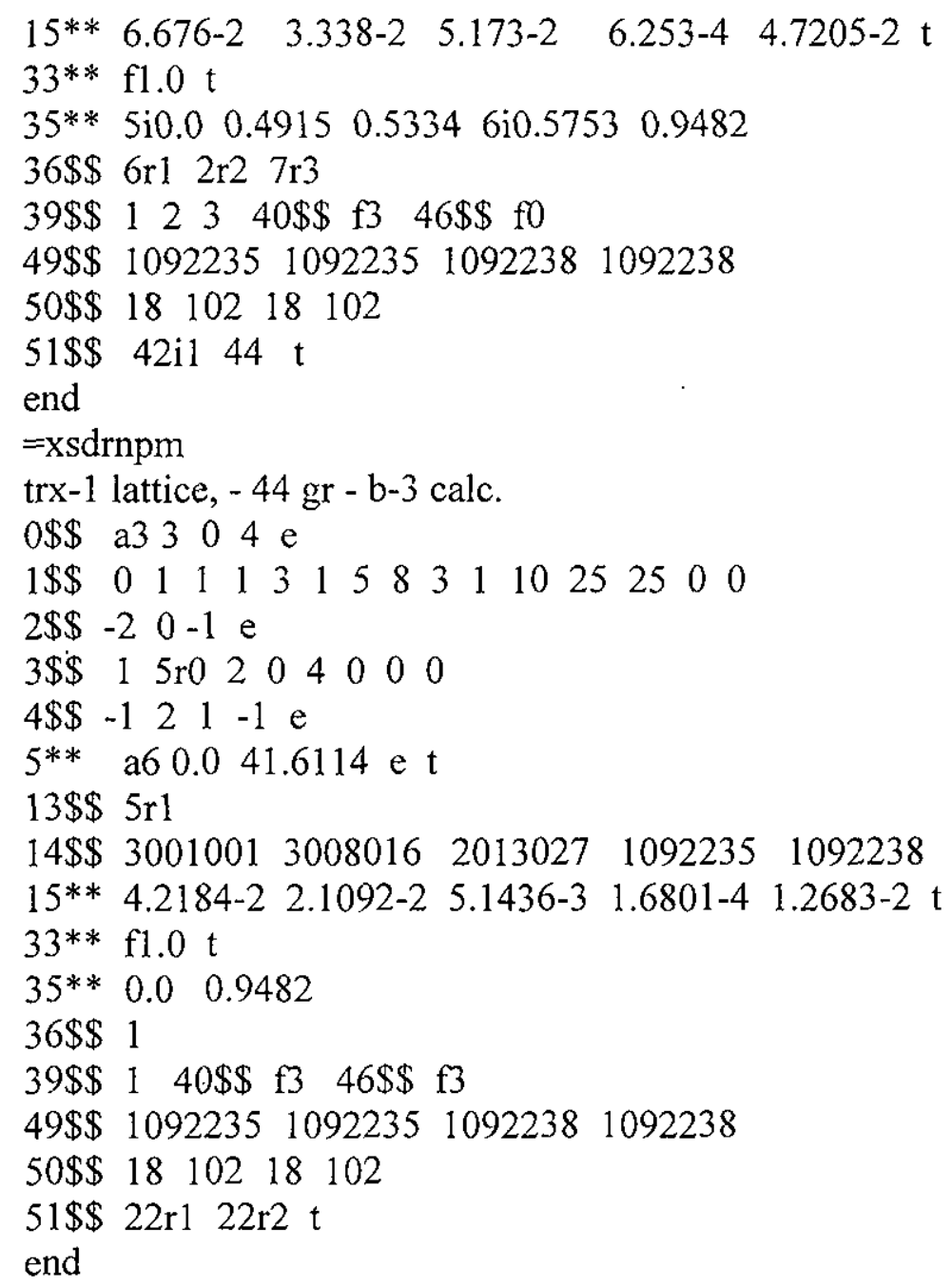

Case UH3xx

References: NUREG/CR-6483 (Emmett and Jordan 1996)/Table 32 TM12460 (DeHart and Bowman 1994)

Specific Cases: Case UH3NI Case UH3NR

Description of UH3NI:

$15.595-\mathrm{cm}(6.140-\mathrm{in}$.$) diameter sphere of highly enriched \mathrm{UH}_{3}$ and carbon with a 20.32$\mathrm{cm}(8.000$-in.) nickel reflector.

Input Listing for Case UH3NI:

\#csasn

UH3NI k-calculation -- 44 gr mdd - 5-06-93

44gr multiregion

h $\quad \begin{array}{llll}1 & 0.0 & 0.0518100 & \text { end }\end{array}$

$\begin{array}{lllll}0 & 1 & 0.0 & 0.0043600 & \text { end }\end{array}$

$\begin{array}{llllll}\text { c } & 1 & 0.0 & 1.9360-2 & \text { end }\end{array}$

$\mathrm{u}-235 \quad 1 \quad 0.0 \quad 1.62700-2$ end

$\begin{array}{lllll}\mathrm{u}-234 & 1 & 0.0 & 1.70000-4 & \text { end }\end{array}$

u-238 $110.0 \quad 1.02000-3$ end

ni $\quad 2 \quad 0.0 \quad 9.03100-2$ end 
HNF-3950 Rev. 0

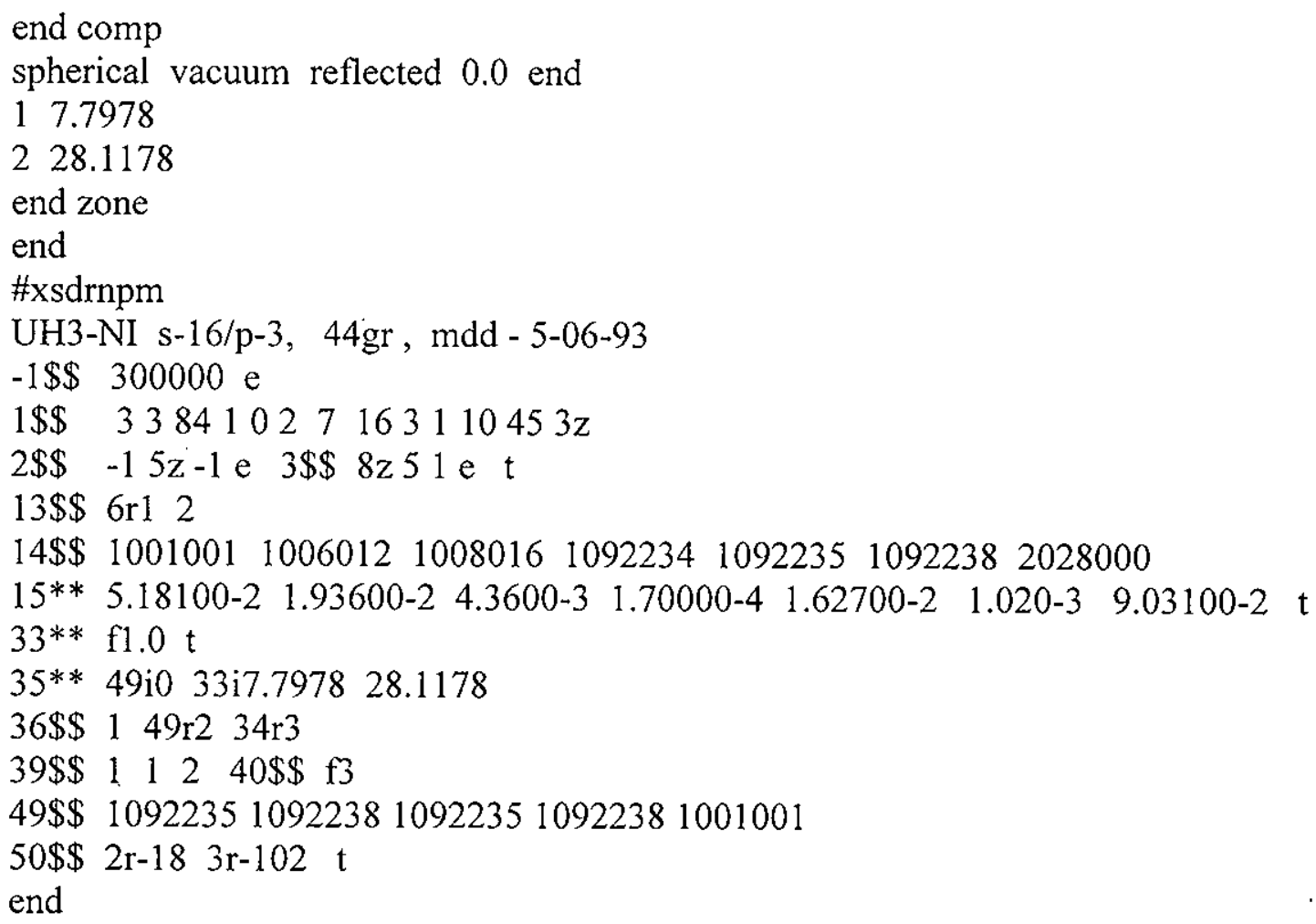

\section{Case ZPRxx}

References: NUREG/CR-6483 (Emmett and Jordan 1996)/Table 32

TM12460 (DeHart and Bowman 1994)

Specific Cases: $\quad$ Case ZPR66A Case ZPR67 Case ZPR311

Case ZPR312

Description of ZPR66A:

191.3-cm (75.3-in.) diameter sphere of enriched uranium oxide mixed with sodium and steel. Surrounded by a 33.8- $\mathrm{cm}$ (13.3-in.) thick reflector of depleted uranium and steel. Input Listing for Case ZPR66A:

\begin{tabular}{lllll} 
=csasn & \multicolumn{4}{c}{ parm $=$ 'size $=30000$} \\
zpr-6/6a & k-calculation -- & 44 \\
44gr multiregion \\
u-233 & 1 & 0.0 & $1.0-15$ & end \\
np-237 & 1 & 0.0 & $1.0-15$ & end \\
pu-239 & 1 & 0.0 & $1.0-15$ & end \\
u-235 & 1 & 0.0 & $1.153-3$ & end \\
u-238 & 1 & 0.0 & $5.8176-3$ & end \\
na & 1 & 0.0 & $9.2904-3$ & end \\
o & 1 & 0.0 & $1.390-2$ & end \\
fe & 1 & 0.0 & $1.3431-2$ & end \\
$\mathrm{cr}$ & 1 & 0.0 & $2.842-3$ & end \\
ni & 1 & 0.0 & $1.291-3$ & end \\
mn & 1 & 0.0 & $2.210-4$ & end \\
u-235 & 2 & 0.0 & $8.56-5$ & end \\
u-238 & 2 & 0.0 & $3.95508-2$ & end
\end{tabular}


$\begin{array}{lllll}\circ & 2 & 0.0 & 2.30-5 & \text { end } \\ \mathrm{fe} & 2 & 0.0 & 4.4669-3 & \text { end } \\ \mathrm{cr} & 2 & 0.0 & 1.247-3 & \text { end } \\ \mathrm{ni} & 2 & 0.0 & 5.407-4 & \text { end } \\ \mathrm{mn} & 2 & 0.0 & 9.60-5 & \text { end }\end{array}$

end comp

spherical vacuum reflected 0.0 end

195.67 noextermod 2129.48 noextermod

end zone

moredata collapse end

end

$=$ xsdrnpm

zpr-6/6a k-calculation -- 44gr, mdd - 5-06-93

$-1 \$ \$ 300000$ e

$1 \$ \$ 33601021843110253 z$

$2 \$ \$-201$ e $3 \$ \$ 8 z 61$ e t

$13 \$ \$ 11 \mathrm{r} 17 \mathrm{r} 2$

$14 \$ \$ 1092233 \quad 109323710942391092235 \quad 109223810110231008016$ 1026000102400010280001025055

2092235209223820080162026000202400020280002025055

$15 * * 3 r 1-15$ 1.153-3 5.8176-3 9.2904-3 $1.390-2$ 1.3431-2 $2.842-3$

1.291-3 2.21-4 8.56-5 3.95508-2 2.30-5 4.4669-3 1.247-3

$5.407-49.529-5 \quad t$

$33 *$ f1.0 t

$\begin{array}{lllllllllll}35 * * & 39 \mathrm{i} 0 & 19 \mathrm{i} & 95.67 & 129.48 & 36 \$ \$ & 1 & 39 \mathrm{r} 2 & 20 \mathrm{r} 3\end{array}$

$39 \$ \$ 111240 \$ \$$

$49 \$ \$ 1092233 \quad 109323710942391092235 \quad 1092238 \quad 1092238$

$50 \$ \$ 5 r-18-102 \mathrm{t}$

end 


\section{B2.0 REFERENCES}

DeHart, M.D., and S. M. Bowman, 1994, Validation of the SCALE Broad Structure 44-Group ENDF-BV Cross Section Library for Use in Criticality Safety Analyses, ORNL/TM12460 (NUREG/CR-6102), Martin Marietta Energy Systems, Inc., Oak Ridge National Laboratory, September, 1994.

Emmett, M. B., and W. C. Jordan, 1996, Guide to Verification and Validation of the SCALE-4 Criticality Safety Software, NUREG/CR-6483 (ORNL/TM-12834), Lockheed Martin Energy Research Corp., Oak Ridge National Laboratory, Oak Ridge, Tennessee.

Primm, R. T., III, 1993, Criticality Safety Studies of Building 3019 Cell 4 and In-Line Storage Wells, ORNL/TM-12374, Martin Marietta Energy Systems, Inc., Oak Ridge National Laboratory, November 1993. 
HNF-3950 Rev. 0

APPENDIX C

INPUT LISTINGS

C-1 
HNF-3950 Rev. 0

This page intentionally left blank. 
HNF-3950 Rev. 0

\section{APPENDIX C}

\section{INPUT LISTINGS}

Input listings are provided for cases run for comparison to Criticality Handbook (Carter et al.1969) data. When water concentration is varied, the case shown is for that concentration which provides the largest value of $\mathrm{k}_{\infty}$.

\section{C1.0 INPUT LISTINGS FOR CRITICALITY HANDBOOK COMPARISONS}

The title cards for each input listing indicates the units for $\mathrm{H}_{2} \mathrm{O}$ (water) as $\mathrm{g} / \mathrm{L}$, but the appropriate units are $\mathrm{g} / \mathrm{cc}$.

\section{C1.1 MINIMUM CRITICAL PLUTONIUM CONCENTRATION IN WATER}

$\mathrm{k}_{\infty}$ is calculated for an infinite volume of ${ }^{239} \mathrm{Pu}$ oxide at a uniform concentration in water. At a concentration of $7.0 \mathrm{~g}^{239} \mathrm{Pu} / \mathrm{L}, \mathrm{k}_{\infty}$ is 0.991547 (Case F10B-6). At a ${ }^{239} \mathrm{Pu}$ concentration of $7.5 \mathrm{~g}{ }^{239} \mathrm{Pu} / \mathrm{L}, \mathrm{k}_{\infty}$ is 1.02676 . Interpolation provides $\mathrm{a} \mathrm{k}_{\infty}$ of 1.000 at $\mathrm{a}^{239} \mathrm{Pu}$ concentration of $7.1 \mathrm{~g} / \mathrm{L}$. The water density is $1 \mathrm{~g} / \mathrm{cc}(1000 \mathrm{~g} / \mathrm{L})$.

XSDRNPM Input Listing For Case F10B-6:

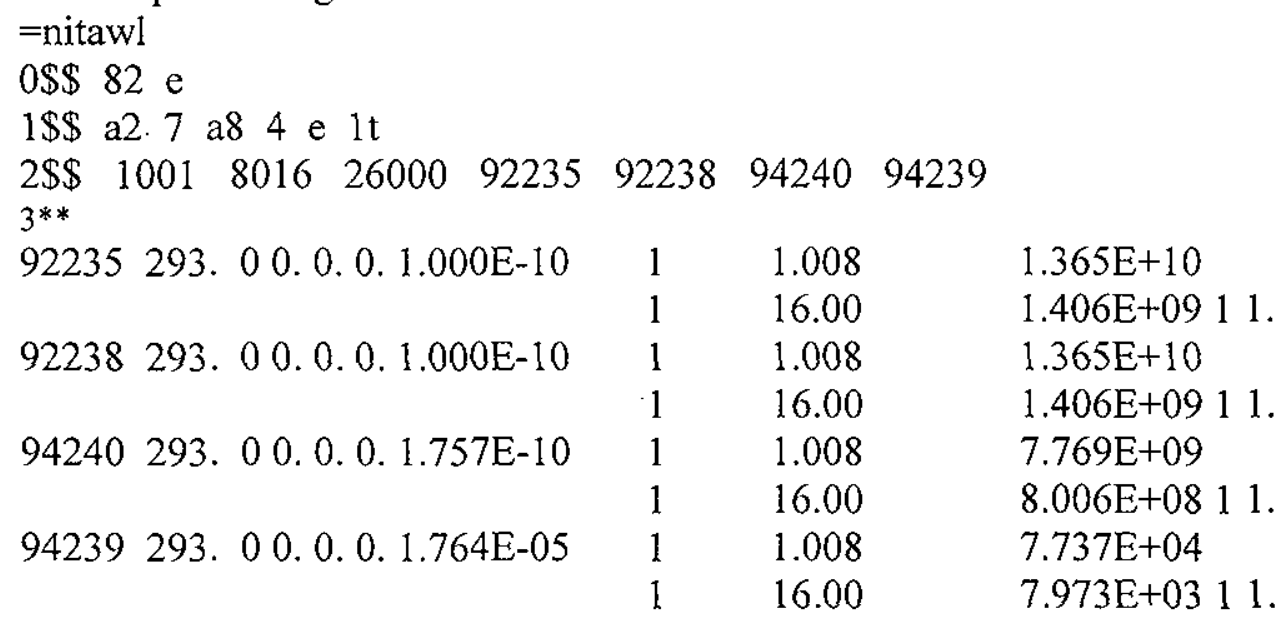

$2 \mathrm{t}$

end

$=x \operatorname{sdrn}$

Case F10B-6, 100\% Pu(0.0) Metal, 7.0 G Pu/L, H2O=1.0 g/L

$\begin{array}{lllllllllllllllll}1 & \$ & 3 & 1 & 32 & 1 & 1 & 1 & 7 & 16 & 1 & 1 & 20 & 10 & 0 & 0 & 0\end{array}$

$2 \$ \$$ a $7-1$ e

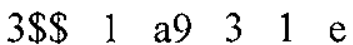

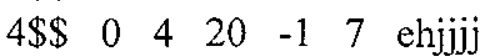

$5 * * 2 \mathrm{r} 1 .-5$ e $1 \mathrm{t}$

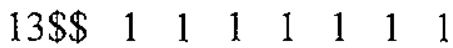

$14 \$ \$ 100180162600092235922389424094239$ 
HNF-3950 Rev. 0

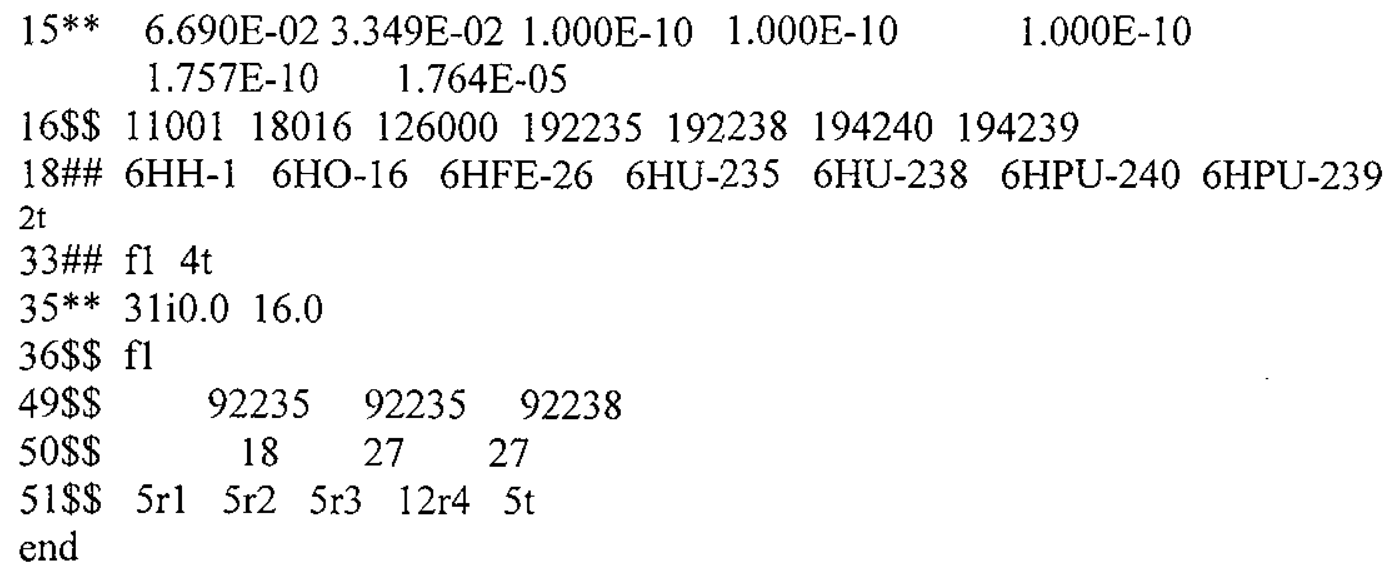

\section{C1.2 $\mathrm{k}_{\infty}$ FOR HOMOGENEOUS PUO ${ }_{2}$ IN WATER}

$\mathrm{k}_{\infty}$ is calculated for an infinite volume of plutonium oxide in a homogeneous water solution. An example is Case F10C-14 for a concentration of $20 \mathrm{~g} \mathrm{Pu} / \mathrm{L}$ with plutonium composed $95 \mathrm{wt} \%$ of ${ }^{239} \mathrm{Pu}$ and $5 \mathrm{wt} \%$ of ${ }^{240} \mathrm{Pu}$. $\mathrm{k}_{\infty}$ is found to be 1.42858 . The water density is $1 \mathrm{~g} / \mathrm{cc}(1000 \mathrm{~g} / \mathrm{L})$.

XSDRNPM Input Listing for Case F10C-14:

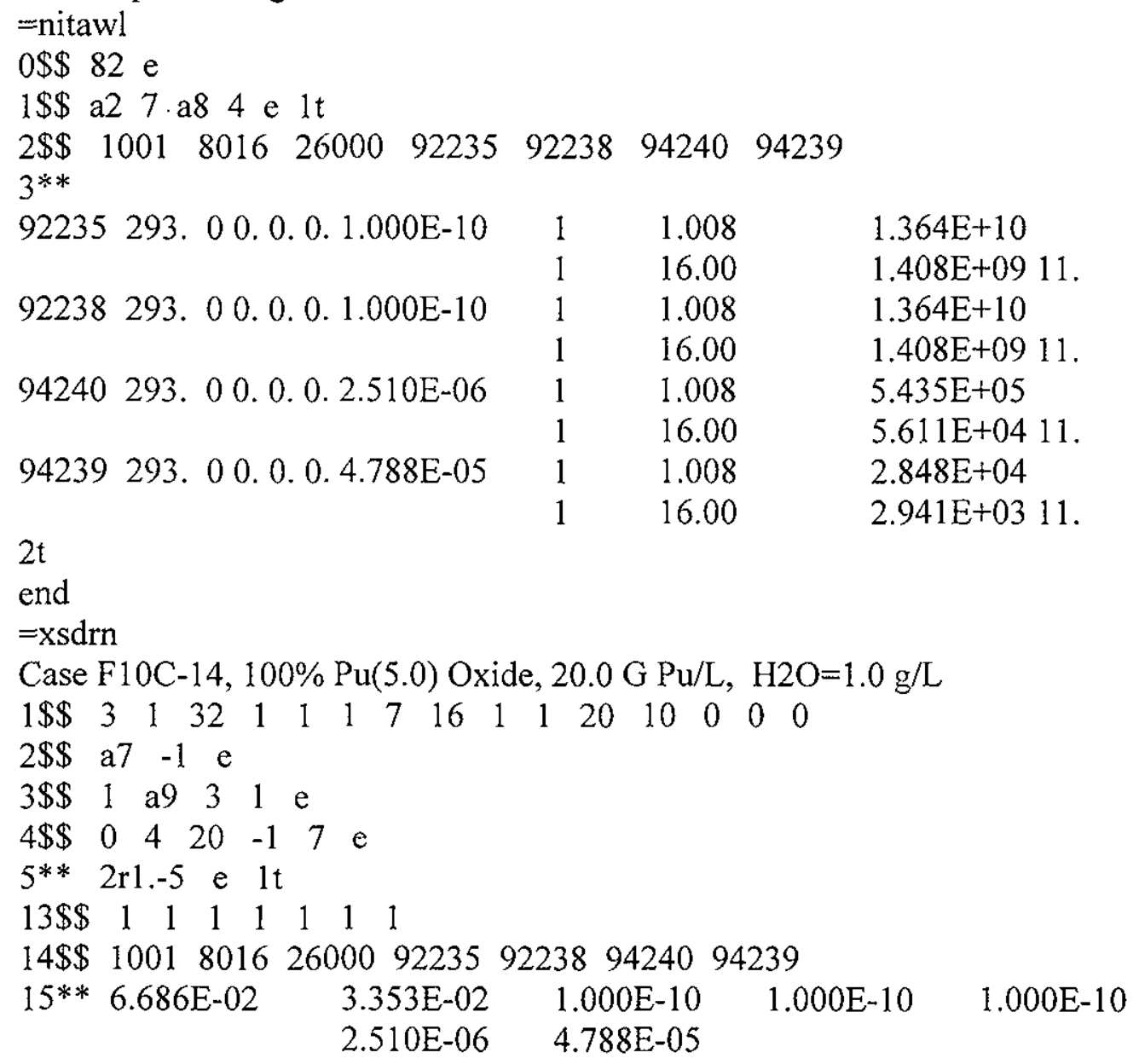


HNF-3950 Rev. 0

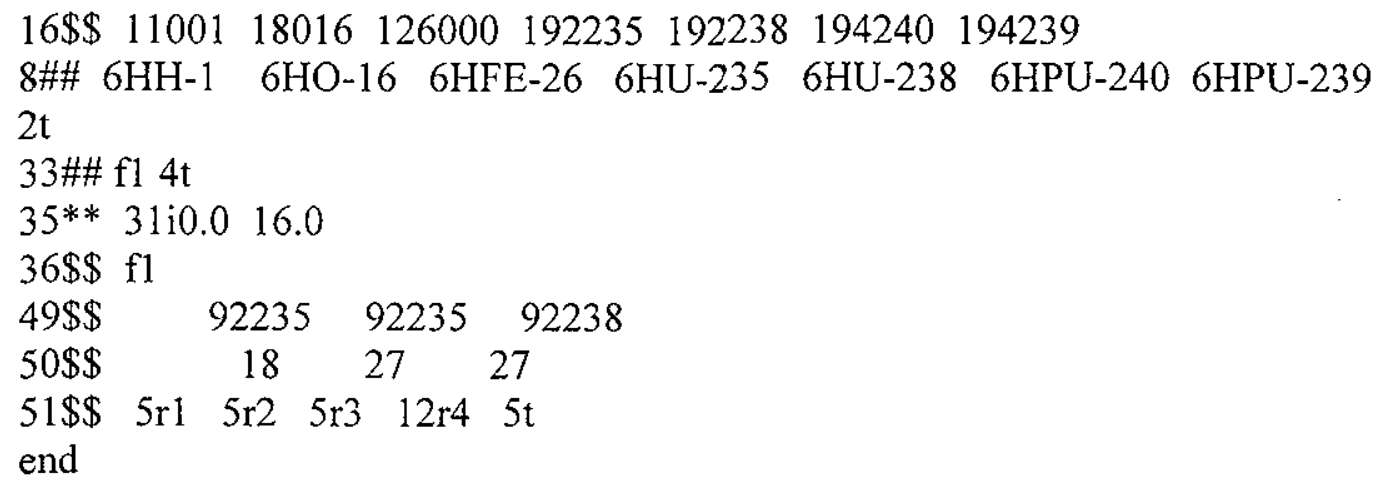

\section{C1.3 $\mathrm{k}_{\infty}$ FOR HOMOGENEOUS $1.25 \mathrm{WT} \% \mathrm{UO}_{2}$ IN WATER}

$\mathrm{k}_{\infty}$ is calculated for $1.25 \mathrm{wt} \%$ enriched $\mathrm{UO}_{2}$ over the entire range of water concentration. The maximum $k_{\infty}$ of 1.06145 occurs at a water density of $0.35 \mathrm{~g} / \mathrm{cc}(350 \mathrm{~g} / \mathrm{L})$ (Case F1A-8). The concentration of $\mathrm{UO}_{2}$ is held constant at $2000 \mathrm{~g} / \mathrm{L}$

XSDRNPM Input Listing for Case F1A-8:

$=$ nitawl

$0 \$ \$ 82 \mathrm{e}$

$1 \$ \$$ a 27 a8 4 e $1 \mathrm{t}$

$2 \$ \$ 1001 \quad 80162600092235922389424094239$ $3 * *$

$\begin{array}{lllllll}92235293.0 & 0.00 .00 .0 & 5.651 \mathrm{e}-05 & 1 & 1.008 & 8.455 \mathrm{e}+03 & 1 \\ & & 1 & 16.068 & 1.534 \mathrm{e}+03 & 11 . \\ 92238293.0 & 0.00 .00 .0 & 4.408 \mathrm{e}-03 & 1 & 1.008 & 1.082 \mathrm{e}+02 & 1 \\ & & 1 & 16.068 & 1.967 \mathrm{e}+01 & 11 . \\ 94240293.00 .00 .00 .0 & 1.000 \mathrm{e}-08 & 1 & 1.008 & 1.000 \mathrm{e}+08 & 1 \\ & & 1 & 16.068 & 1.000 \mathrm{e}+08 & 11 . \\ 94239293.0 & 0.00 .00 .0 & 1.000 \mathrm{e}-08 & 1 & 1.008 & 1.000 \mathrm{e}+08 & 1 \\ & & 1 & 16.068 & 1.000 \mathrm{e}+08 & 11 .\end{array}$

$2 \mathrm{t}$

end

$=$ xsdrn

Case F1A-8, U(1.25) Oxide, $2000 \mathrm{~g} / \mathrm{L}, \mathrm{FeO} / \mathrm{UO} 2=0.0, \mathrm{H} 2 \mathrm{O}=0.35 \mathrm{~g} / \mathrm{L}$ $1 \$ \$ 3 \quad 132111117 \begin{array}{llllllllll} & & 16 & 1 & 1 & 20 & 10 & 0 & 0 & 0\end{array}$

$2 \$ \$$ a7 -1 e

$3 \$ \$ 1$ a9 3 1 e

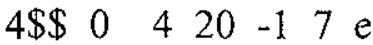

$5 * * 2 \mathrm{r} 1 .-5$ e $1 \mathrm{t}$

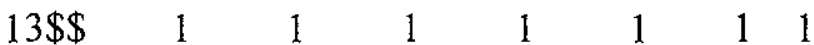

$14 \$ \$ 1001 \quad 8016 \quad 26000 \quad 92235 \quad 92238 \quad 94240 \quad 94239$

$\begin{array}{llllllll}15 * * & 2.342-2 & 2.062-2 & 1.000-8 & 5.651-5 & 4.408-3 & 1.000-8 & 1.000-8\end{array}$

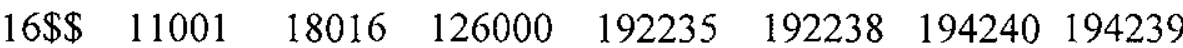

$18 \# \#$ 6HH-1 $6 \mathrm{HO}-16 \quad 6 \mathrm{HFe}-26 \quad 6 \mathrm{HU}-235 \quad 6 \mathrm{HU}-238 \quad 6 \mathrm{HPu}-2406 \mathrm{HPu}-2392 \mathrm{~T}$ 


\section{HNF-3950 Rev. 0}

$33 \# \# \mathrm{fl} \quad 4 \mathrm{t}$

$35 * 3110.016 .0$

$36 \$ \$ \mathrm{fl}$

$49 \$ \$ 922359223592238$

$\begin{array}{llll}50 \$ \$ & 18 & 27 & 27\end{array}$

$\begin{array}{llllll}51 \$ 5 & 5 \mathrm{r} 1 & 5 \mathrm{r} 2 & 5 \mathrm{r} 3 & 12 \mathrm{r} 4 & 5 \mathrm{t}\end{array}$

end

KENO V.a Input Listing for Case F1A-8:

$=\operatorname{csas} 25$

kfla-8

27group infhommedium

$\mathrm{u}-235105.6510 \mathrm{e}-5$ end

$\mathrm{u}-238 \quad 1 \quad 04.4080 \mathrm{e}-3$ end

pu-239 $101.0000 \mathrm{e}-8$ end

pu-240 $101.0000 \mathrm{e}-8$ end

h $\quad 102.3420 \mathrm{e}-2$ end

o $\quad 102.0620 \mathrm{e}-2$ end

fe $\quad 101.0000 \mathrm{e}-8$ end

end comp

Case F1A-8, U(1.25) Oxide, $2000 \mathrm{~g} / \mathrm{L}, \mathrm{FeO} / \mathrm{UO} 2=0.0, \mathrm{H} 2 \mathrm{O}=0.35 \mathrm{~g} / \mathrm{L}$

read param gen $=405 \mathrm{npg}=600 \mathrm{nsk}=5 \mathrm{wrs}=34$

res $=205 \mathrm{nub}=$ yes $\mathrm{fdn}=$ yes $\mathrm{run}=$ yes plt=no end param

read geom

cuboid $11100.0-100.0100 .0-100.0100 .0-100.0$

end geom

read bnds

all $=$ mirror

end bnds

end data.

end

\section{C2.0 SLUDGE CONFIGURATIONS}

Case F9D-6 is representative of tank waste configurations. $\mathrm{k}_{\infty}$ is calculated for uranium containing $0.84 \mathrm{wt} \%{ }^{235} \mathrm{U}$ and $0.30 \mathrm{wt} \%$ plutonium. The plutonium contains $16 \mathrm{wt} \%{ }^{240} \mathrm{Pu}$. The $\mathrm{FeO} / \mathrm{HMO}$ mass ratio is 0.60 (equivalent to a $\mathrm{Fe} / \mathrm{HM}$ mass ratio of 0.529 ). The water content is $0.25 \mathrm{~g} / \mathrm{cc}(250 \mathrm{~g} / \mathrm{L})$. The XSDRNPM calculated $\mathrm{k}_{\infty}$ is 0.74536 , and the KENO V.a $\mathrm{k}_{\infty}$ is 0.7377 \pm 0.0008 .

XSDRNPM Input Listing for Case F9D-6:

$=$ nitawl

$0 \$ \$ 82 \mathrm{e}$

$1 \$ \$$ a2 7 a8 4 e $1 \mathrm{t}$

$2 \$ \$ 1001 \quad 8016 \quad 26000 \quad 92235 \quad 92238 \quad 94240 \quad 94239$

C-6 
HNF-3950 Rev. 0

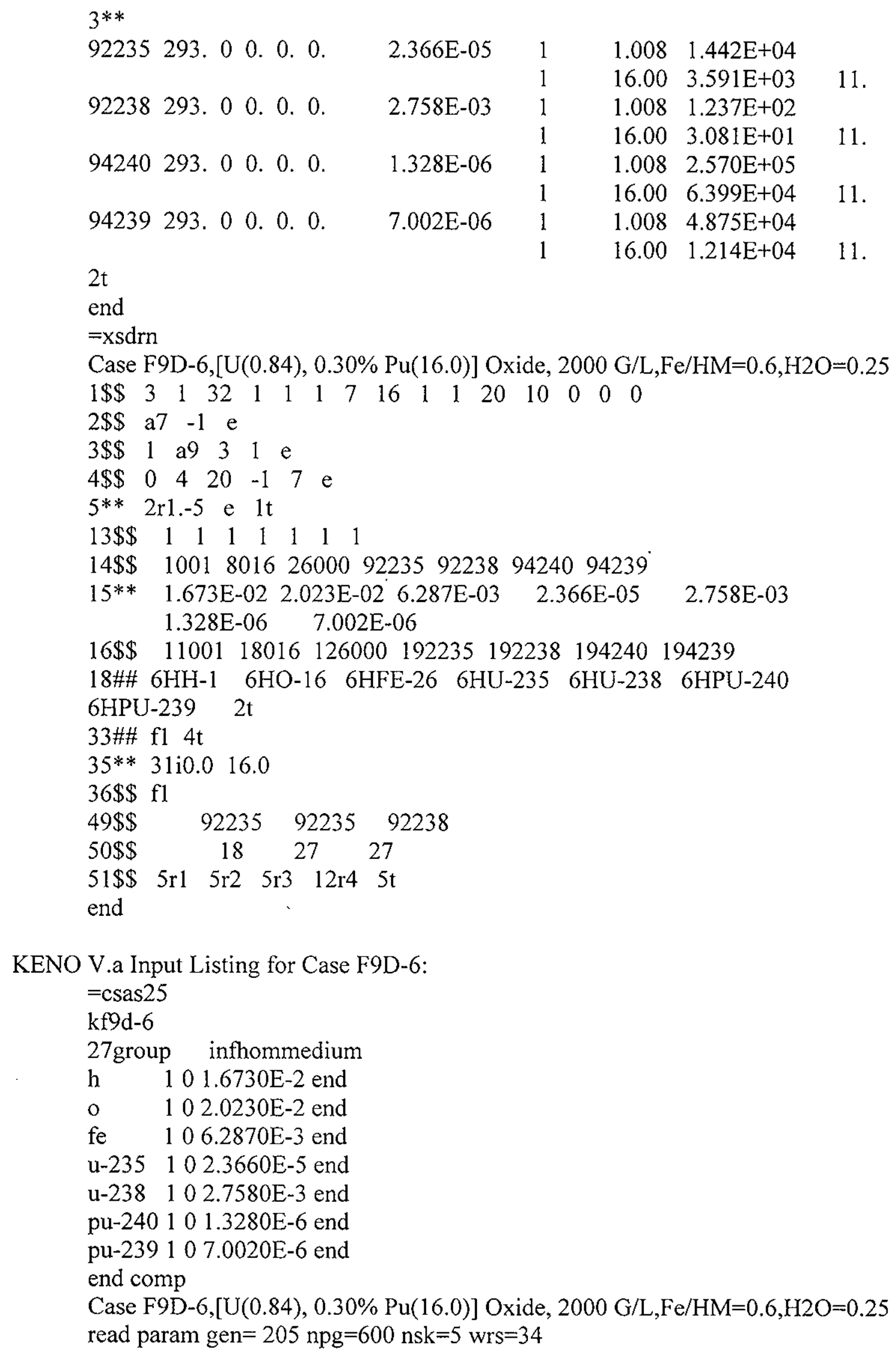


HNF-3950 Rev. 0

nub=yes $\mathrm{fdn}=$ yes run=yes $\mathrm{plt}=$ no end param

read geom

cuboid $11100.0-100.0100 .0-100.0100 .0-100.0$

end geom

read bnds

all=mirror

end bnds

end data

end 
HNF-3950 Rev. 0

\section{C3.0 REFERENCES}

Carter, R. D., G. R. Kiel, and K. R. Ridgway, 1969, Criticality Handbook, ARH-600, Vol. II, Atlantic Richfield Hanford Company, Richland, Washington.

Greene, N. M., and L. M. Petrie, 1995m "XSDRNPM: A one-Dimensional Discrete-Ordinates Code for Transport Analysis," Sect. F3 of SCALE, A Modular Code System for Performing Standardized Computer Analyses for Licensing Evaluation, NUREG/CR0200, Rev. 4 (ORNL/NUREG/CSD-2/R4), Vol. I, II, III, April 1995.

Petrie, L. M., and N. F. Landers, 1995, “KENO V.a: An Improved Monte Carlo Criticality Program with Supergrouping," Sect. FII of SCALE, A Modular Code System for Performing Standardized Computer Analyses for Licensing Evaluation, NUREG/CRE0200, Rev. 4 (ORNL/NUREG/CSD-2/R4), Vols. I, II, III, April 1995. Available from Radiation Shielding Information Center at Oak Ridge National Laboratory as CCC-545. 
HNF-3950 Rev. 0

This page intentionally left blank. 
HNF-3950 Rev. 0

APPENDIX D

INDEPENDENT REVIEW

D-1 


\section{HNF-3950 Rev. 0}

This page intentionally left blank. 


\section{HNF-3950 Rev. 0}

\section{APPENDIX D}

\section{INDEPENDENT REVIEW}

Mr. Warren D. Wittekind of Fluor Daniel Northwest, Criticality \& Shielding organization performed an independent peer review. The following is his description of this review.

\section{D1.0 REVIEW}

\section{D1.1 LOGIC OF THE CODE VALIDATION}

This validation for the XSDRNPM code drew heavily on the software resources available from the SCALE internet web site. The SCALE input files were downloaded from:

$$
\text { http://www.ornl.gov/pub/rsic/scale4.3/critv v.exe. }
$$

This is a self-extracting ZIP file and the SCALE input files are available. Selected cases can then be executed from these input files.

When all the selected cases are executed, then the statistical calculations are also available (the USLSTATS code) from this web site to calculate the upper safety limit based on the SCALE input file results. These upper safety limits were then reported as the main results of this code validation document. The entire process is standardized and automated with reduced chance for error.

\section{D1.2 SCOPE OF THIS INDEPENDENT PEER REVIEW}

The SCALE input files were independently recovered from the SCALE internet web site. The independently recovered SCALE input files were checked with listings in this document, and where there was a question about identical values, the SCALE output file was compared directly to these independently downloaded files.

Selected standard SCALE input files were verified: the input was correct and the stated output was correctly translated into the document. The tabulated SCALE case results were used as input files into the USLSTATS code, and this was assumed to have been performed carefully.

Results of the USLSTATS code were then incorporated into tables in this report. The lowest values from the USLSTATS code were then used as the upper safety limits. These values comprise the final result of this validation report, and this was assumed to have been performed carefully.

Conclusions drawn from the results of the USLSTATS code were considered. Any high correlation coefficients were considered, as well as any possible biases introduced from any category of the benchmark cases. The recommendations are consequences of this consideration of the USLSTATS results. 


\section{HNF-3950 Rev. 0}

\section{D1.3 COMMENTS ON THE VALIDATION REPORT}

The logic of the validation calculation is indisputable. The accuracy of the SCALE input files was verified. The correctness of copying the SCALE output results was verified on selected samples. The entire process is standardized and automated with reduced change for logic error.

The selection of which SCALE input cases are chosen and how the results are grouped for input into USLSTATS is a value judgement, and may differ between criticality safety specialists. The XSDRNPM code is expected to be applied to low enrichment uranium, $0.60 \mathrm{wt} \%{ }^{235} \mathrm{U}$ minimum up to $1.25 \mathrm{wt} \%{ }^{235} \mathrm{U}$ maximum, smaller proportions of plutonium, up to a maximum of 0.0030 weight fraction of the uranium present, and plutonium compositions with a maximum of 16.6 $\mathrm{wt} \%{ }^{240} \mathrm{Pu}$. The iron to uranium composition for the basin sludge is expected to exceed the ratio $\mathrm{Fe} / \mathrm{U}=0.70$.

- There were 19 uranium benchmark cases that were ${ }^{235} \mathrm{U}$ enriched, 5 were enriched to approximately $1.30 \mathrm{wt} \%{ }^{235} \mathrm{U}, 4$ were enriched to 10 to $20 \mathrm{wt} \%{ }^{235} \mathrm{U}$, while the other 10 were very highly enriched at $90 \mathrm{wt} \%{ }^{235} \mathrm{U}$. The correlation coefficient, $\mathrm{r}^{2}$, of $\mathrm{k}_{\text {eff }}$ to ${ }^{235} \mathrm{U}$ enrichment was a high 0.863 for the 44-group calculation and there was an apparent bias due to the uranium ${ }^{235} \mathrm{U}$ enrichment. This bias was in the conservative direction, the low enrichments calculated the highest $\mathrm{k}_{\mathrm{effs}}$.

- There were 14 plutonium benchmark cases and all but 1 involved the ${ }^{240} \mathrm{Pu} w \mathrm{w} \%$ less than $11.8 \mathrm{wt} \%{ }^{240} \mathrm{Pu}$, that is the expected range. There was no bias apparent due to the plutonium ${ }^{240} \mathrm{Pu}$ composition.

- There were 6 iron critical benchmark cases and the iron composition was a maximum of $\mathrm{Fe} / \mathrm{HM}=0.453$ ratio. Two iron benchmarks were in the thermal neutron energy range (highest $\mathrm{Fe} / \mathrm{HM}=0.005$ ), while 4 , including the highest $\mathrm{Fe} / \mathrm{HM}$ ratio, were in the fast range. The iron concentration expected in the modeled system $\mathrm{Fe} / \mathrm{HM}=0.7$ contained enough iron to be substantially subcritical. There was no bias apparent due to the $\mathrm{Fe} / \mathrm{HM}$ mass ratio over the narrow range of the iron benchmarks.

- There were $13{ }^{233} \mathrm{U}$ critical benchmark cases that used an isotope that is not of concern in the modeled system. The results are different from all other calculations, as can be seen from the low USL ${ }_{1}$ S reported in the final table with USLSTATS results tabulated that an undesirable bias maybe introduced for the 27-group calculations. This bias toward lower $\mathrm{USL}_{1} \mathrm{~S}$ are in the fast neutron energy category.

- The 10 iron plate KENO V.a benchmark cases did add confirmation that the iron composition was being correctly calculated by the XSDRNPM code.

The sum of $10+14+6+13+13$ is 52 , but 6 were counted in two different categories, so there was only a total of 46 different benchmark cases. There was an obvious consistency between the criticality calculations for all the different situations confirming valid application of the XSDRNPM code to this modeled system. This selection of benchmark cases appears to be adequate for validation. 


\section{HNF-3950 Rev. 0}

Another possible value judgement involved how to specify the limits for the XSDRNPM output results into the USLSTATS code. The average energy group (AEG) and the average energy causing fission (AEF) are both output from XSDRNPM and are not subject to value judgements. The hydrogen to heavy metal ration, $\mathrm{H} / \mathrm{HM}$ for a fast system is very low and may be assumed to be zero.

\section{D1.4 REVIEW COMMENT RECORD}

A Review Comment Record (RCR) is provided with comments that required a response by the author. The disposition of these comments is shown on the RCR. 


\begin{tabular}{|l|l|l|l|}
\hline \multirow{2}{*}{ REVIEW COMMENT RECORD (RCR) } & 1. Date $03 / 30 / 99$ & 2. Review No. \\
\cline { 2 - 4 } & 3. Project No. & 4. Page \\
\hline
\end{tabular}

\begin{tabular}{|c|c|c|c|c|}
\hline $\begin{array}{l}\text { 5. Document Kumber(s)/Title(s) } \\
\text { HNF-3950, Rev. O, Verification and } \\
\text { Validation of XSDRNPM Code for Tank } \\
\text { Waste Calculations. }\end{array}$ & $\begin{array}{l}\text { 6. Program/Project/ } \\
\text { Buil lding Number. }\end{array}$ & $\begin{array}{l}\text { 7. Reviewer } \\
\text { Warren D. Wittekind }\end{array}$ & $\begin{array}{l}\text { 8. Organization/Group } \\
\text { Fluor Daniel } \\
\text { Northwest/ } \\
\text { Criticality and } \\
\text { Shielding }\end{array}$ & $\begin{array}{l}\text { 9. Location/Phone } \\
\text { B4-44/376-8175 }\end{array}$ \\
\hline
\end{tabular}

17. Comment Submittal Approval:

10. Agreement with indicated coment disposition(s)

11. CLOSED

\begin{tabular}{|c|c|c|c|c|c|}
\hline \multicolumn{2}{|r|}{ Drganization Manager (optional) } & \multicolumn{2}{|c|}{$\begin{array}{l}\text { Reviewer/Point of contact } \\
\text { Choules Rogens }\end{array}$} & \multicolumn{2}{|c|}{ Reviewer/Point of contact } \\
\hline $\begin{array}{l}12 . \\
\text { Item }\end{array}$ & $\begin{array}{l}\text { 13. Comment(s)/oiscrepancy(s) (Provide technical justification for the } \\
\text { comment and detailed recommendation of the action required to correct/ } \\
\text { resolve the discrepancy/problem indicated.) }\end{array}$ & $\begin{array}{l}14 . \\
\text { Hold } \\
\text { Point }\end{array}$ & 15. Disposition (Provide justification & if Nor accepted.) & $\begin{array}{l}16 . \\
\text { Status }\end{array}$ \\
\hline 1. & $\begin{array}{l}\text { A value judgement is the selection of the } \\
\left.\text { administrative margin as } 0.10 \text { ( } k_{\text {imit }}=0.90\right) \text { instead } \\
\text { of } 0.02 \text { (klimit }=0.98) \text { or } 0.05\left(k_{\text {limit }}=0.95\right) \text {. This } \\
\text { has to do with the simplicity and similarity of the } \\
\text { modeled system with the benchmark cases. The } \\
\text { dominant constituent is low enrichment uranium, next } \\
\text { is the iron, and finally the plutonium. The } \\
\text { benchmark cases available considered high }{ }^{235} \mathrm{U} \\
\text { enrichment, high }{ }^{233} \mathrm{U} \text { enrichment, plutonium systems } \\
\text { and some cases with some iron involved. The choice } \\
\text { of the } 0.10 \text { administrative margin is reasonable, } \\
\text { defensible and conservative. }\end{array}$ & & $\begin{array}{l}\text { Author concurs with comment. } \\
\text { action required. }\end{array}$ & No further & \\
\hline
\end{tabular}




\begin{tabular}{|l|l|l|}
\hline \multirow{2}{*}{ REVIEW COMMENT RECORD (RCR) } & $\begin{array}{l}\text { 1. Date Review No. } \\
03 / 30 / 99\end{array}$ & 2. \\
\cline { 2 - 4 } & 3. Project No. & 4. Page \\
\hline
\end{tabular}

\begin{tabular}{|c|c|c|c|c|}
\hline $\begin{array}{l}12 . \\
\text { Item }\end{array}$ & $\begin{array}{l}\text { 13. Corment(s)/Discrepancy(s) (Provide technical justification for the } \\
\text { cament and detailed recommendation of the action required to correct/ } \\
\text { resolve the discrepancy/problem indicated.) }\end{array}$ & $\begin{array}{l}14 . \\
\text { sold } \\
\text { Point }\end{array}$ & 15. Disposition (Provide justification if Nor accepted.) & $\begin{array}{l}16 . \\
\text { status }\end{array}$ \\
\hline 2. & $\begin{array}{l}\text { It is recommended to exclude the } 233 \mathrm{U} \text { benchmarks from } \\
\text { the final upper safety limit calculation. The } \\
\text { benchmarks are fast systems and do seem to introduce } \\
\text { some downward bias on the upper safety limit for the } \\
27 \text { group XSDRNPM calculations, from the final upper } \\
\text { safety limit calculation. This is relevant because } \\
\text { at the end of the conclusions section, the } 27 \text { group } \\
\text { upper safety limit is recommended for both the } 27 \\
\text { group and } 44 \text { group calculations. }\end{array}$ & & $\begin{array}{l}\text { The Uranium-233 fast data was not included. } \\
\text { However, the Uranium- } 233 \text { thermal data was } \\
\text { included. These data will be removed, and } \\
\text { the Upper Safety Limit will be recalculated. } \\
\text { Table } 7-1 \text { will be revised. }\end{array}$ & \\
\hline
\end{tabular}




\begin{tabular}{|l|l|l|l|}
\hline \multirow{2}{*}{ REVIEW COMMENT RECORD (RCR) } & 1. Date Review No. & $03 / 30 / 99$ \\
\cline { 2 - 3 } & 3. Project No. & 4. Page 3 of 4 \\
\hline
\end{tabular}

\begin{tabular}{|c|c|c|c|c|}
\hline $\begin{array}{l}12 . \\
1 \text { tem }\end{array}$ & $\begin{array}{l}\text { 13. Comment (s)/Discrepancy(s) (Provide technical justification for the } \\
\text { comment and detailed recomendation of the action required to correct/ } \\
\text { resolve the discrepancy/problem indicated.) }\end{array}$ & $\begin{array}{l}14 . \\
\text { Hold } \\
\text { Point }\end{array}$ & 15. Disposition (Provide justification if NOT accepted.) & $\begin{array}{l}16 . \\
\text { Status }\end{array}$ \\
\hline 3 . & $\begin{array}{l}\text { It is also recommended that the final calculation } \\
\text { for the upper safety limit should include both fast } \\
\text { and thermal systems together. Since the uranium and } \\
\text { plutonium tend to collect in the sludge layer where } \\
\text { the H/HM is lower, it makes sense to include both } \\
\text { the thermal and fast systems together for the final } \\
\text { upper safety limit calculation so that the H/HM } \\
\text { range of applicability will not be limited at some } \\
\text { arbitrary H/HM ratio. Additionally, four of the six } \\
\text { Fe/U benchmarks are for fast systems, and } \\
\text { considering only the thermal systems, as was done, } \\
\text { includes only two Fe/U and the highest Fe/U=0.005, } \\
\text { much lower than the range of application which is } \\
\text { expected to be >Fe/U=0.70. Furthermore, consider } \\
\text { the description of water content from WHC-SD-SQA- } \\
\text { CSA-507, Rev. 0, Criticality Parameters for Tank } \\
\text { Waste Evaluation, which states: "Water content in } \\
\text { waste varies from very high in supernatant liquid to } \\
\text { relatively low in dry waste. . At the very low } \\
\text { plutonium concentration in waste, optimal water } \\
\text { content is generally a state of extreme dryness. } \\
\text { (section } 3.3 .2 \text { ) " This published description infers } \\
\text { that the thermal and fast benchmark measurements } \\
\text { should both be used in the XSDRNPM validation } \\
\text { because there is no artificial H/HM ratio, such as } \\
\text { H/HM=loo, that divides off an irrelevant area for } \\
\text { waste tank criticality code validation. }\end{array}$ & $x$ & $\begin{array}{l}\text { The report includes evaluation of an Upper } \\
\text { Safety Limit with all } 46 \text { experiments. } \\
\text { However, this is not applicable to } K \text { Basin } \\
\text { Sludge or existing tank wastes because the } \\
\text { sludge and/or wastes cannot be dried to the } \\
\text { point of producing a fast system. } \\
\text { In CSA-507, "optimal water content" means } \\
\text { optimal moderation. At that point the } \\
\text { system is not a fast system. The } H / X \text { range } \\
\text { stated in the report applies to the range of } \\
\text { benchmark data and is not artificially } \\
\text { chosen. The H/X limit has been modified to } \\
\text { a description of AEF to more clearly } \\
\text { represent moderation in the system. }\end{array}$ & \\
\hline
\end{tabular}


HNF-3950 Rev. 0

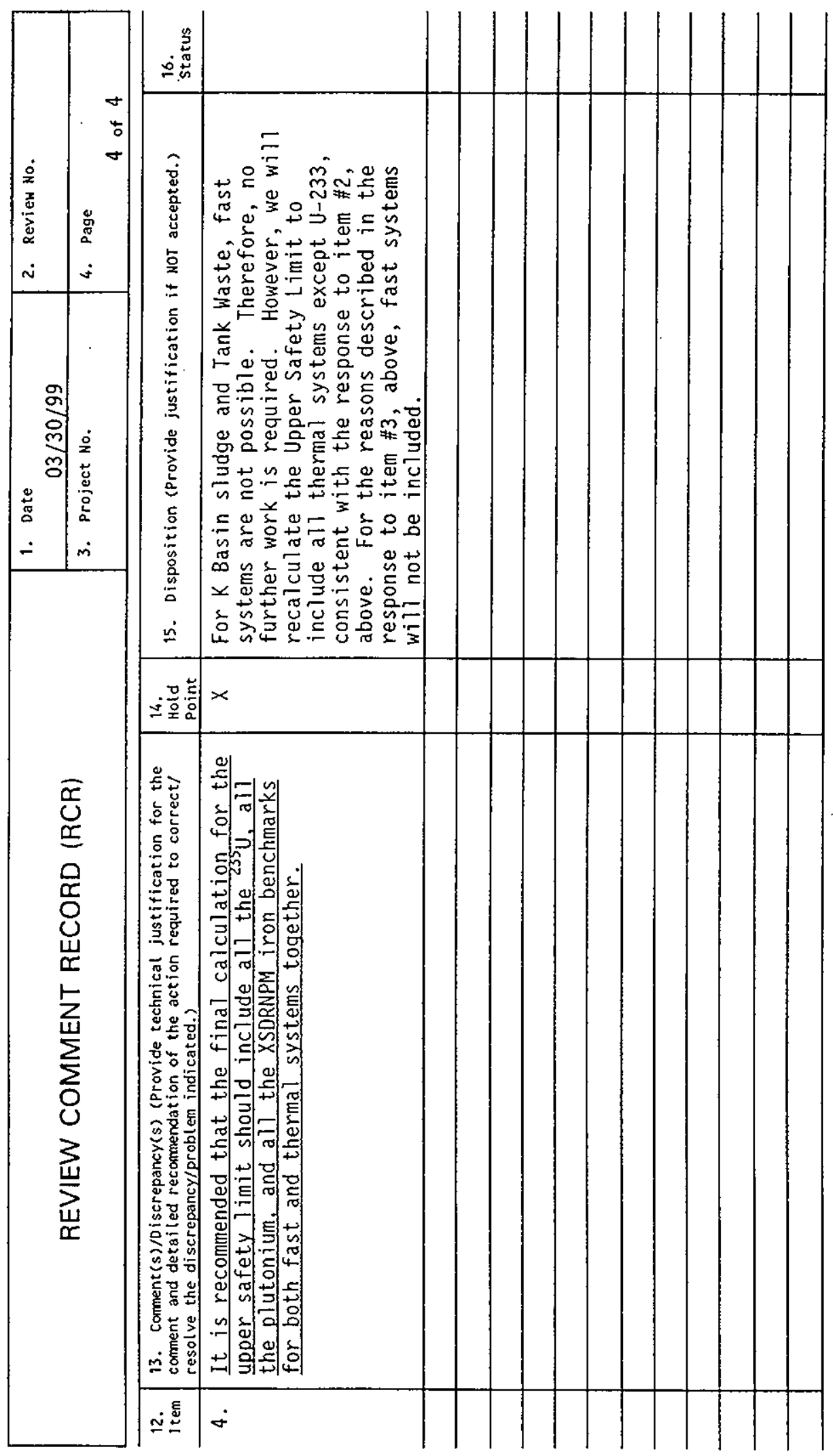

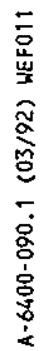


HNF-3950 Rev. 0

This page intentionally left blank.

D-10 
DISTRIBUTION SHEET

To

Distribution

Project Title/Work Order

Verification and Validation of XSDRNPM Code for Tank Waste Calculations

Name

$\mathrm{FDH}$

S. T. Almodovar

J. E. Fialkovich

LMHC

D. R. Bratzel

R. J. Cash

C. E. Leach

E. J. Lipke

J. E. Meacham

C. A. Rogers

(6)

L. E. Thomas

DESH

M. C. Brady Raap

FDNW

J. P. Estareliado

K. N. Schwinkendorf

W. D. Wittekind

NHC

F. W. Moore

K. L. Pearce

WMH

T. S. Vail

DOE

D. H. Alexander

(3)

S. J. Altschuler

L. T. Nirider
From

NS\&L/Criticality support

(19)

Text 1 Attach /

With All Text Only Appendix

Attach.

Only

EDT/ECN

Only 


\section{DISTRIBUTION SHEET}

To

Distribution

Project Title/Work Order

Verification and Validation of XSDRNPM Code for Tank Waste Calculations

\begin{tabular}{|l}
\hline \multicolumn{1}{|c|}{ Name } \\
\hline Offsite \\
\hline Adolf S. Garcia, US DOE-ID \\
\hline 850 Energy Drive \\
\hline Idaho Falls, ID 83401 \\
\hline \\
\hline Dr. Jerry MCKamy, US DOE \\
\hline 19901 Germantown Rd. \\
\hline Germantown, MD 20874-129 \\
\hline \\
\hline Dr. Kevin A. Niemer \\
\hline Duke Engineering, MSIN WC-26B \\
\hline 400 S. Tryon St. \\
\hline Charlotte, NC 28201 \\
\hline
\end{tabular}

SNE Project Files A-13B

Central Files
From

NS\&L/Criticality Support

NPM Code for Tank Waste

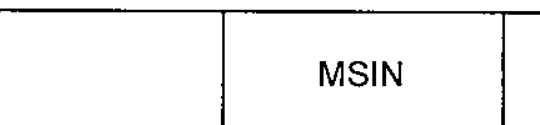

Text With All

Attach.
Page 2 of 2

Date May 26, 1999

EDT No. 625119

ECN No. NA

Attach Text Only Appendix Appendix

EDT/ECN Only 